MÁRCIA CRISTINA MENÃO

Indução de mutação por uma substância química em cepas de Escherichia coli para a atenuação e o desenvolvimento de vacina contra a colibacilose aviária

São Paulo

2013 


\section{Indução de mutação por uma substância química em cepas de Escherichia coli para a atenuação e o desenvolvimento de vacina contra a colibacilose aviária}

Tese apresentada ao Programa de PósGraduação em Epidemiologia Experimental Aplicada às Zoonoses da Faculdade de Medicina Veterinária e Zootecnia da Universidade de São Paulo para a obtenção do título de Doutor em Ciências.

\section{Departamento:}

Medicina Veterinária Preventiva e Saúde Animal

Área de concentração:

Epidemiologia Experimental Aplicada às Zoonoses

Orientador:

Prof. Dr. Antonio José Piantino Ferreira

São Paulo 
Autorizo a reprodução parcial ou total desta obra, para fins acadêmicos, desde que citada a fonte.

DADOS INTERNACIONAIS DE CATALOGAÇÃO-NA-PUBLICAÇÃO

(Biblioteca Virginie Buff D’Ápice da Faculdade de Medicina Veterinária e Zootecnia da Universidade de São Paulo)

T.2771

Menão, Márcia Cristina

Indução de mutação por uma substância química em cepas de Escherichia coli para a
atenuação e o desenvolvimento de vacina contra a colibacilose aviária / Márcia Cristina Menão. -- 2013.

$100 \mathrm{f}$ : : il.

Tese (Doutorado) - Universidade de São Paulo. Faculdade de Medicina Veterinária e Zootecnia. Departamento de Medicina Veterinária Preventiva e Saúde Animal, São Paulo, 2013.

Programa de Pós-Graduação: Epidemiologia Experimental Aplicada às Zoonoses.

Área de concentração: Epidemiologia Experimental Aplicada às Zoonoses.

Orientador: Prof. Dr. Antonio José Piantino Ferreira.

1. Escherichia coli. 2. Substância mutagênica. 3. Fatores de virulência. 4. Aves. 5. Mutação. I. Título. 


\section{FACULDADE DE MIDICINA VETERINARIA E TOOTECNIA}

\section{Comissão de Ética no uso de Animais}

Of. CEUAVET no 174/FMVZ/2012.

rcg

São Paulo, 24 de setembro de 2012.

Ao sr.

Prof. Dr. Antonio José Piantino Ferreira

Assunto: Projeto no 2751/2012, intitulado “Indução da mutação em cepas de Escherichia coli por antimicrobiano para controle da colibacilose aviária".

A Comissão de Ética no uso de Animais desta Faculdade, analisou os protocolos acima mencionados e solicita a Vossa Senhoria esclarecer:

- em relação à aquisição dos animais, não é informado se os mesmos serão comprados ou doados e a exata procedência do referido criatório comercial;

- o item 10.4 indica que não serão usados fármacos analgésicos justificando que o experimento induz dores nos animais. A presente afirmação necessita de melhor fundamento para justificar a manutenção da dor nos animais, mesmo que em breve período de tempo.

Atenciosamente,

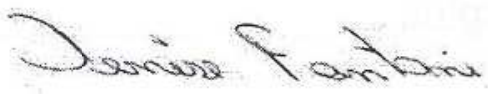

Denise Tabacchi Fantoni

Presidente 


\section{FOLHA DE AVALIAÇÃO}

Nome: MENÃO, Márcia Cristina

Título: Indução de mutação por uma substância química em cepas de Escherichia coli para a atenuação e o desenvolvimento de vacina contra a colibacilose aviária

Tese apresentada ao Programa de PósGraduação em Epidemiologia Experimental Aplicada às Zoonoses da Faculdade de Medicina Veterinária e Zootecnia da Universidade de São Paulo para a obtenção do título de Doutor em Medicina Veterinária.

Data:

1

Banca examinadora

Prof. Dr.

Instituição:

Julgamento:

Prof. Dr.

Instituição: Julgamento:

Prof. Dr.

Instituição: Julgamento:

Prof. Dr.

Instituição: Julgamento:

Prof. Dr.

Instituição: Julgamento: 
DEDICATÓRIA 
A meus pais por todo amor e apoio... Aos meus amados filhos Lucas e Pedro, razões da minha vida... A meu marido Cesar, pelo amor e incentivo... 
AGRADECIMENTOS 
À Deus pela vida e a oportunidade de um aprendizado diário.

Ao Prof. Dr. Antonio José Piantino Ferreira por todas as orientações, ensinamentos, compreensão e paciência.

Aos meus pais Milson e Maria Eugênia por todo amor, incansável dedicação, apoio, carinho e exemplo de luta durante toda minha vida.

Aos meus filhos Lucas e Pedro pela compreensão dos muitos momentos de ausência, companheirismo, amor incondicional e por tornarem meus dias mais felizes.

A meu marido César por todo apoio, companheirismo e esforço para compensação de minhas inúmeras ausências.

À Profa. Dra. Terezinha Knöbl pela amizade, incentivo, ajuda e por não me permitir desistir nunca.

À Profa. Dra. Claudete Astolfi Ferreira pela amizade, por todas as ideias, incentivo e inúmeras correções na tese.

À Profa. Dra. Andrea Micke Moreno pela amizade, sugestões e desenvolvimento do AFLP.

A minha sobrinha Júlia por todo carinho e momentos de muita alegria.

Aos meus irmãos Marcos e Mileni e minha cunhada Elaine pelo apoio e companheirismo.

Aos meus grandes amigos José Domingues e José Aparecido e ao Laboratório Biovet por toda colaboração no decorrer deste trabalho.

Aos funcionários do Laboratório de Ornitopatologia da FMVZ, Dennis e Maurício por toda ajuda, paciência e pelo convívio extremamente agradável nestes anos. 
Aos amigos do Laboratório de Ornitopatologia da Universidade de São Paulo: Maria Eugênia, Luciana Alegretti, Luciana Scanavini, Luis, Silvana, Gabrielle, Natalia, Marta, Yamê e Pedro pela convivência agradável e troca de experiências.

Aos amigos Marcos Paulo, Mirela e Maria Gabriela pelo auxílio nas análises de PCR.

Aos amigos Ketrin e Vasco do Laboratório de Sanidade Suína pelo desenvolvimento de análises laboratoriais. 
Há duas formas para viver a sua vida: Uma é acreditar que não existe milagre. A outra é acreditar que todas as coisas são um milagre. 
RESUMO 


\section{RESUMO}

MENÃO, M. C. Indução de mutação por uma substância química em cepas de Escherichia coli para a atenuação e o desenvolvimento de vacina contra a colibacilose aviária. [Mutations induced by a chemical in strains of Escherichia coli to the attenuation and vaccine development against avian colibacillosis]. 2013. $100 \mathrm{f}$. Tese (Doutorado em Ciências). Faculdade de Medicina Veterinária e Zootecnia, Universidade de São Paulo, São Paulo, 2013.

A colibacilose aviária caracteriza-se como uma infecção extra-intestinal secundária a outros agentes. É responsável por grandes perdas econômicas na criação de aves comerciais, sendo sua prevenção fundamental para minimizar prejuízos. $O$ objetivo deste estudo foi atenuar cepas virulentas de Escherichia coli aviárias, por indução de mutagênese química. Foram selecionadas nove (09) cepas pertencentes à coleção de cultura do Laboratório de Ornitopatologia da FMVZ-USP. Todas as cepas estudadas foram resistentes à eritromicina, lincomicina, oxaciclina, penicilina, tiamulina e tilmicosin e sensíveis ao ácido nalidíxico, cloranfenicol, ciprofloxacina, colistina, enrofloxacina, florfenicol e gentamicina. Ocorreram resistências nas amostras analisadas de 33,33\%, 22,22\%, 11,11\%, 55,55\%, 66,66\%, 77,77\%, $33,33 \%, 22,22 \%, 22,22 \%$ e $33,33 \%$, respectivamente, a amoxacilina, a ampicilina, a doxaciclina, a espectiomicina, a estreptomicina, a lincomicina-espectiomicina, a neomicina, a rifampicina, a tetraciclina e ao trimetropin-sulfa. Induziu-se resistência a estreptomicina ou rifampicina ou ácido nalidíxico como marcadores. Não houve o desenvolvimento de resistências a outros antimicrobianos testados, após a exposição a substância mutagênica. Os resultados da amplificação dos genes por PCR, mostraram que todas as cepas foram negativas para papC, cnf e astA e todas foram positivas para iuc e irp2. Duas cepas foram positivas para os genes vat, cinco para iss, quatro para o gene tsh, uma para cvi/cva, duas para sfal e uma para astA. Após o uso da substância mutagênica duas cepas apresentaram reações negativas para os genes tsh, cvi/cva e sfal e uma cepa para o gene astA. No teste de AFLP verificaram-se diferenças em similaridade de bandas em oito (08) das nove (09) cepas, quando comparadas com a amostra tratada com a substância mutagênica, sendo que este indice variou de $40 \%$ a $96,3 \%$. Embora no teste de patogenicidade em pintinhos de um dia de idade não tenha ocorrido diferenças significativas na mortalidade nos diferentes grupos estudados, houve alteração de patogenicidade 
em cinco cepas expostas à substância mutagênica. Ocorreram reduções significativas em relação ao escore de lesões quando os grupos foram comparados $(p<0,05)$, indicando atenuação pela substância mutagênica.

Palavras-chave: Escherichia coli. Substância mutagênica. Fatores de virulência. Aves. Mutação. 
ABSTRACT

MENÃO, M. C. Mutations induced by a chemical in strains of Escherichia coli to the attenuation and vaccine development against avian colibacillosis [Indução de mutação por uma substância química em cepas de Escherichia coli para a atenuação e o desenvolvimento de vacina contra a colibacilose aviária]. 2013. $100 \mathrm{f}$. Tese (Doutorado em Ciências). Faculdade de Medicina Veterinária e Zootecnia, Universidade de São Paulo, São Paulo, 2013.

The avian colibacillosis is characterized as an extraintestinal infection which is secondary to other agents. It is responsible for considerable economic loss in the breeding of commercial birds, making its prevention essential to reducing damages. The aim of this study was to attenuate viral strains of avian Escherichia coli, using chemical mutagenesis induction. Nine (09) strains were selected from the culture collection of the Ornitopathology Laboratory of the School of Veterinary Medicine of the University of São Paulo. All analyzed strains were resistant to erythromycin, lincomicin, oxacillin, penicillin, tiamulin and tilmicosin and they were sensitive to nalidixic acid, chloramphenicol, ciprofloxacin, colistin, enrofloxacin, florfenicol and gentamicin. The analyzed samples presented the following resistance levels: $33.33 \%, 22.22 \%, 11.11 \%, 55.55 \%, 66.66 \%, 77.77 \%, 33.33 \%, 22.22 \%, 22.22 \%$ and $33.33 \%$ to, respectively, amoxicillin, ampicillin, doxycycline, spectinomycin, streptomycin, lincomycin-spectinomycin, neomycin, rifampicin, tetracycline and trimethoprim-sulfa. The resistance to streptomycin or rifampicin or nalidixic acid was induced as a marker. There was no development of resistance to other tested antimicrobials after the exposure to the mutagenic substance. The results of the PCR gene amplification showed that all strains were negative for papC, cnf and astA and they were all positive for iuc and irp2. Two strains were positive for the vat genes, five for iss, four for the tsh gene, one for cvi/cva, two for sfal and one for astA. After using the mutagenic substance, two strains presented negative reactions for the tsh, cvi/cva and sfal genes and one strain for the astA gene. In the AFLP test, differences were found for band similarity in eight (08) out of nine (09) strains, when compared with the samples treated with the mutagenic substance and this rate varied from $40 \%$ to $96.3 \%$. Although the pathogenicity test in one-day-old chicks did not present significant differences in the mortality rate in the different analyzed groups, there was 
a pathogenicity alteration in five strains exposed to the mutagenic substance. There were significant reductions regarding the lesion scores when the groups were compared $(p<0,05)$, indicating an attenuation due to the mutagenic substance.

Keywords: Escherichia coli. Mutagenic substance. Virulence factors. Birds. Mutation. 


\section{LISTA DE QUADROS}

Quadro 1 Mecanismos de resistência entre bactérias e suas bases

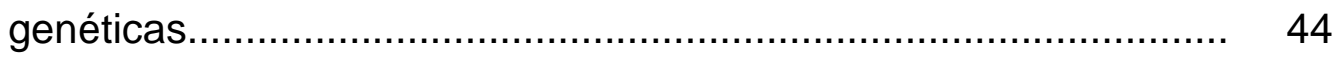

Quadro 2 Identificação das amostras de E. coli, sorotipo, origem e órgão de

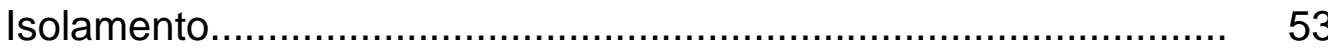

Quadro 3 Genes de virulência pesquisados pela reação de polimerase em cadeia.

Quadro 4 Cepas de E. coli e antibióticos utilizados para a indução de resistência...

Quadro 5 Grupos de aves e cepas de E. coli utilizadas para a inoculação das aves.

Quadro 6 Cepas de E. coli e concentrações utilizadas para a inoculação, por via saco aéreo de pintinhos SPF de um dia de idade

Quadro 7 Escore de lesão para sacos aéreos, serosa hepática e pericárdio.. 
LISTA DE TABELAS 


\section{LISTA DE TABELAS}

Tabela 1 Resultados dos testes de suscetibilidade a antimicrobianos (mg/L), no teste de difusão em disco (TDD) em mm e no teste de concentração inibitória mínima em $\mu \mathrm{g} / \mathrm{mL}$

Tabela 2 Resultados da amplificação dos genes de virulência por PCR nas cepas selvagens ou tratadas com substância mutagênica.

Tabela 3 Mortalidade de pintinhos SPF inoculados com cepas de E. coli selvagens ou com mutações nos 10 dias de observação e a classificação de patogenicidade.

Tabela 4 Número de pintinhos com lesão provocada por cepas selvagens de E. coli ou tratadas com a substância mutagênica após 10 dias da inoculação.

Tabela 5 Escore de lesões em sacos aéreos de aves inoculadas com cepas de $E$. coli classificadas em um escore de 0 a 4

Tabela 6 Escore de lesões em coração de aves com cepas de E. coli classificadas em um escore de 0 a 4 .

Tabela 7 Diferenças entre cepas selvagens e com mutações em relação a fatores de virulência, similaridade em AFLP, patogenicidade, mortalidade e escore de lesões. 
LISTA DE FIGURAS 


\section{LISTA DE FIGURAS}

Figura 1 Eletroforese em gel de agarose 1,5\%. Perfis obtidos através do AFLP em amostras de E. coli selvagens ou tratadas com substância mutagênica....................................................................... $\quad 70$

Figura 2 Comparação de bandas entre as cepas EC 269 S e EC 269 M...... 71

Figura 3 Comparação de bandas entre as cepas EC 341 S e EC 341 M...... 71

Figura 4 Comparação de bandas entre as cepas EC 713 S e EC 713 M...... 71

Figura 5 Comparação de bandas entre as cepas EC 775 S e EC 775 M...... 72

Figura 6 Comparação de bandas entre as cepas EC 1299 S e EC 1299 M.. 72

Figura 7 Comparação de bandas entre as cepas EC 1669 S e EC 1669 M.. 72

Figura 8 Comparação de bandas entre as cepas EC 1708 S e EC 1708 M.. 73

Figura 9 Comparação de bandas entre as cepas EC 1869 S e EC 1869 M.. 73

Figura 10 Comparação de bandas entre as cepas EC 1889 S e EC 1889 M.. 73

Figura 11 Mortalidade total de pintinhos SPF inoculados com as cepas de $E$. coli selvagens ou com mutações, nos 10 dias de observação..........

Figura 12 Número de aves com lesões após 10 dias de inoculação de cepas de E. coli selvagens ou com mutações 
LISTA DE ABREVIATURAS 


\section{LISTA DE ABREVIATURAS}

$\begin{array}{ll}\text { AFLP } & \text { Polimorfismo do comprimento de fragmentos amplificados } \\ \text { APEC } & \text { Escherichia coli patogênica aviária } \\ \text { astA } & \text { Gene codificador da toxina enteroagregativa termo estável } \\ \text { cvi/cva } & \text { Gene codificador do plasmídeo da colicina V } \\ \text { DAEC } & \text { Escherichia coli de aderência difusa } \\ \text { DNA } & \text { Ácido desoxirribonucléico } \\ \text { dNTP } & \text { Deoxirribonucleotídeo } \\ \text { EAGGEC } & \text { Escherichia coli enteroagregativa } \\ \text { EC } & \text { Escherichia coli } \\ \text { EIEC } & \text { Escherichia coli enteroinvasora } \\ \text { EHEC } & \text { Escherichia coli enterohemorrágica } \\ \text { EPEC } & \text { Escherichia coli enteropatogênica } \\ \text { ETEC } & \text { Escherichia coli enterotoxigênica } \\ \text { hly } & \text { Gene codificador da } \alpha \text {-hemolisina } \\ \text { irp2 } & \text { Gene de proteína repressível por ferro (Iron repressible protein } \\ & \text { yersínia-bactin synthesis) } \\ \text { iss } & \text { Gene codificador da proteína para o aumento de sobrevivência no soro } \\ \text { iuc } & \text { Gene codificador da aerobactina } \\ \text { Kb } & \text { Quilobases } \\ \text { M } & \text { Molar } \\ \text { MIC } & \text { Minimum inhibitory concentration } \\ \text { mL } & \text { Mililitro (10-3) } \\ \text { mM } & \text { Milimolar (10 } \\ \text { neuS } & \text { Gene da cápsula K1 } \\ \text { NMEC } & \text { Escherichia coli de meningite neonatal } \\ \text { papC } & \text { Gene codificador do pili associado com pielonefrite } \\ \text { pb } & \text { Pares de bases } \\ \text { PCR } & \text { Reação em cadeia pela polimerase } \\ \text { pH } & \text { Potencial hidrogeniônico } \\ \text { SPF } & \text { Livre de patógenos específicos } \\ \text { STEC } & \text { E. coli produtora de toxina Shiga-like } \\ \end{array}$


tsh Gene codificador da hemaglutinina sensível a temperatura

$\mu$ Micrograma $\left(10^{-6}\right.$ grama)

UFC Unidades formadoras de colônias

UPEC E. coli uropatogênica

$\mu \mathrm{L} \quad$ Microlitro $\left(10^{-6}\right.$ litro)

$\quad$ Micromolar $\left(10^{-6}\right.$ Molar)

vat Gene da toxina vacuolizante

Nota: em função do uso consagrado na literatura técnica, algumas abreviaturas utilizadas seguem as iniciais da sua grafia no idioma inglês. 
SUMÁRIO 
$1 \quad$ INTRODUÇÃO

$2 \quad$ REVISÃO DE LITERATURA .................................................... 32

$2.1 \quad$ ESCHERICHIA COLI........................................................ 33

$2.2 \quad$ COLIBACILOSE AVIÁRIA............................................................ 34

$2.3 \quad$ FATORES DE VIRULÊNCIA ...................................................... 36

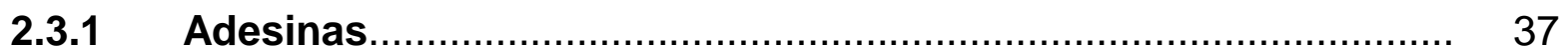

2.3.2 Hemaglutinina sensível à temperatura .......................................... 38

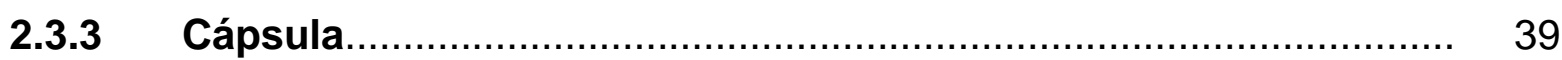

2.3.4 Alfa-hemolisina ................................................................ 40

2.3.5 Resistência sérica.......................................................... 41

2.3.6 Sistema de aquisição de ferro .................................................. 41

$2.4 \quad$ RESISTÊNCIA A ANTIMICROBIANOS........................................ 42

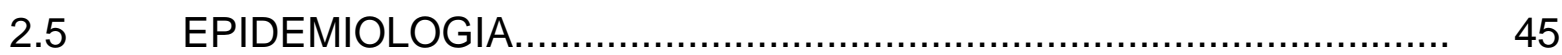

2.6 MUTAGÊNESE BACTERIANA .............................................. 46

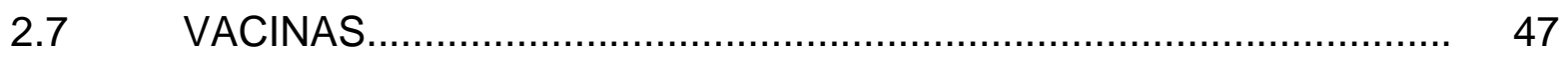

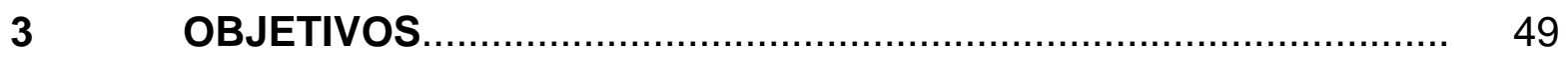

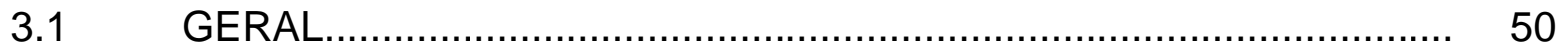

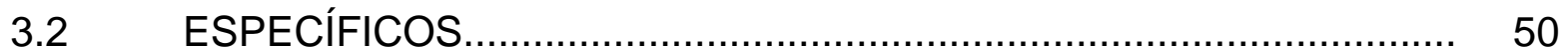

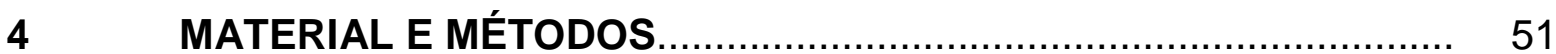

4.1 AMOSTRAS BACTERIANAS ................................................ 52

4.2 EXTRAÇÃO DO DNA E REAÇÃO EM CADEIA PELA POLIMERASE

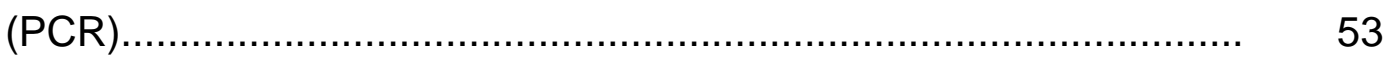

4.2.1 Determinação dos fatores de virulência....................................... 53

4.3 TESTES DE SUSCETIBILIDADE A ANTIMICROBIANOS................ 54

4.3.1 Concentração inibitória mínima.................................................. 55

4.3.2 Técnica de difusão em disco..................................................... 56

4.3.3 Indução de resistência a antimicrobianos.................................... 56

4.4 INDUÇÃO DE MUTAÇÃO POR SUBSTÂNCIA MUTAGÊNICA........... 57

4.5 POLIMORFISMO DO COMPRIMENTO DE FRAGMENTOS AMPLIFICADOS (AFLP) .............................................................. 57 
4.6 TESTE DE PATOGENICIDADE EM PINTINHOS DE UM DIA DE IDADE

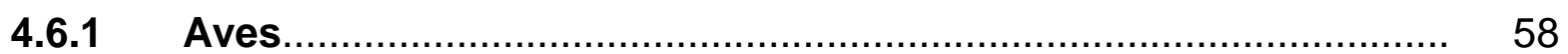

4.6.2 Delineamento experimental............................................... 58

4.6.3 Teste de patogenicidade.................................................. 59

$5 \quad$ ANÁLISE ESTATÍSTICA ................................................... 61

5.1 ANÁLISE ESTATÍSTICA DE AFLP........................................... 61

5.2 ANÁLISE ESTATÍSTICA DE PATOGENICIDADE E ESCORE DE

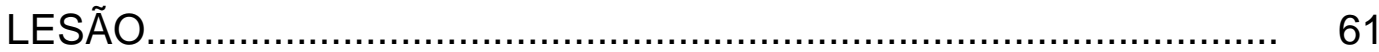

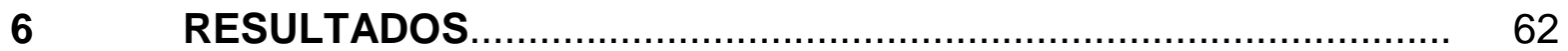

6.1 SUSCETIBILIDADE A ANTIMICROBIANOS ................................ 63

6.1.1 Concentração inibitória mínima (MIC) ..................................... 63

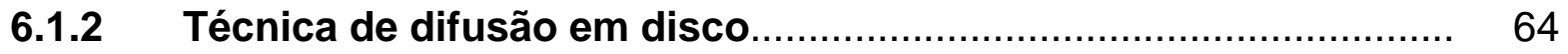

6.2 INDUÇÃO DE RESISTÊNCIA A ANTIMICROBIANOS...................... 64

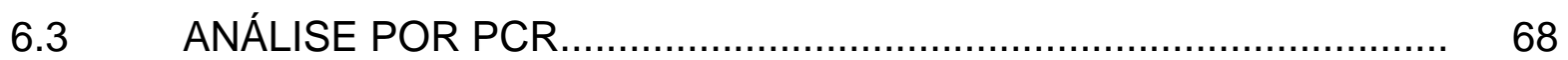

6.4 CARACTERIZAÇÃO GENOTÍPICA POR AFLP............................ 69

6.5 AVALIAÇÃO DE PATOGENICIDADE DE CEPAS SELVAGENS OU TRATADAS COM SUBSTÂNCIA MUTAGÊNICA EM PINTINHOS DE UM DIA DE IDADE................................................... 74

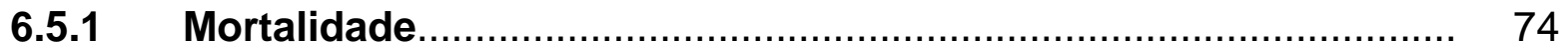

6.5.2 Escore de lesões................................................................... 76

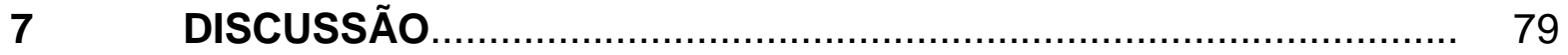

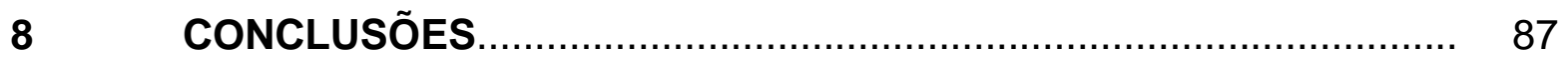

REFERÊNCIAS ............................................................ 89 
INTRODUÇÃO 


\section{INTRODUÇÃO}

A indústria avícola representa um dos mais importantes segmentos do agronegócio. Alcançou nas últimas décadas um grande desenvolvimento em função da crescente demanda por produtos avícolas pela população mundial e contínua agregação de novas tecnologias. Atualmente possui como principais características a alta produção, a boa qualidade dos produtos e os baixos custos (GIMENO, 2009; SALLE; MORAES, 2009).

No Brasil mais de 12 mil toneladas de carne de frango foram produzidas no ano de 2011, sendo o país o terceiro produtor mundial e líder em exportações (APINCO, 2012). Segundo o Ministério da Agricultura Pecuária e Abastecimento, até 2020, a expectativa é que a produção nacional de carne de frango seja responsável por $48,1 \%$ das exportações mundiais (BRASIL, 2012).

O melhoramento genético, a nutrição balanceada e a sanidade em uma produção intensiva foram os fatores responsáveis para que estes índices de produtividade fossem alcançados. Entretanto, novos desafios surgiram, dentre eles os problemas sanitários decorrentes de situações de estresse geradas por este moderno tipo de criação, além disso, a intensificação da produção também induz a perdas econômicas e a alteração da qualidade do alimento produzido (BARNES; VAILLANCOURT; GROSS, 2003; GIMENO, 2009).

Uma das doenças que se destacam neste cenário é a colibacilose aviária, causada pela Escherichia coli patogênica para aves (APEC) que é considerada secundária a outros agentes e tem manifestações clínicas extra-intestinais. Este agente pode ocasionar diversos quadros clínicos como colisepticemia, peritonite, pneumonia, pleuropneumonia, aerossaculite, pericardite, doença respiratória crônica complicada (DRCC), onfalite, osteomielite e ooforite gerando extensivas perdas econômicas, decorrentes do tratamento e baixa produtividade, podendo também ocasionar mortalidade (BARNES; VAILLANCOURT; GROSS, 2003; FERREIRA; KNÖBL, 2009).

Várias proteínas estão associadas à virulência de Escherichia coli (E. coli) em aves, incluindo adesinas, proteínas que induzem resistência sérica e produção de sideróforos, sendo que a combinação destas pode aumentar a patogenicidade e potencializar os prejuízos (ROCHA et al., 2008). 
A utilização de aditivos na dieta, como promotores de crescimentos, é uma das estratégias para a alta produtividade. Esses são definidos como substâncias adicionadas às rações, sem valor nutricional, capazes de melhorar o desempenho animal ou as características físicas dos alimentos (SILVA, 2000; ARAUJO et al., 2007). O principal promotor de crescimento utilizado no Brasil e países cujas leis não imponham restrições, desde a década de 50 é o antibiótico (BARNES; VAILLANCOURT; GROSS, 2003; ANDREATTI FILHO, 2007). Este quando utilizado em doses sub-terapêuticas na ração, possui a função de impedir a invasão e multiplicação de micro-organismos patogênicos no intestino do animal, permitindo assim, que os nutrientes da dieta sejam aproveitados pelo hospedeiro (FLEMMING, 2005; ARAUJO et al., 2007).

No entanto, o uso contínuo destes produtos na alimentação animal pode contribuir para o desenvolvimento de populações de bactérias resistentes que podem se disseminar no ambiente e na microbiota intestinal podendo possibilitar que essa resistência seja transferida a micro-organismos patogênicos, dificultando tratamentos, constituindo um risco tanto para a saúde animal quanto humana (LODDI, 2003, SINGER; HOFACRE, 2006).

Consequentemente, a vacinação das aves torna-se uma ferramenta imprescindível contra a doença. Entretanto, as vacinas inativadas com adjuvantes oleosos podem induzir reações adversas. Dessa forma, o desenvolvimento de vacinas atenuadas é uma opção para a imunização, pois além de produzirem menores reações adversas podem ser utilizadas por via aerossol ou água de bebida (BARNES; VAILLANCOURT; GROSS, 2003).

A atenuação de cepas induzida por mutação pode representar uma alternativa para o desenvolvimento dessas vacinas atenuadas. Peighmbari et al. (2002) testaram duas vacinas elaboradas com cepas de $E$. coli mutante, dos sorogrupos $\mathrm{O} 2$ e 078 , em frangos de corte e concluíram que as aves vacinadas com o sorogrupo O2 apresentaram diferença significativa na redução de lesões em sacos aéreos quando comparadas as aves do grupo controle.

Neste trabalho foi investigada se a exposição à substância mutagênica poderia induzir mutações em cepas de E. coli para um futuro desenvolvimento de vacinas atenuadas. 
REVISÃO DE LITERATURA 


\section{REVISÃO DE LITERATURA}

\subsection{ESCHERICHIA COLI}

Escherichia coli é uma bactéria pertencente à família Enterobacteriaceae descrita pela primeira vez por Theodor Von Escherich em 1885, a partir de fezes de crianças sadias, sendo nomeada inicialmente de Bacterium coli commune (BETTELHEIM, 1994; TRABULSI; ALTHERTUM, 2005).

É um bastonete curto, com coloração Gram negativa, não formador de esporos, anaeróbio facultativo e que faz parte da microbiota intestinal de seres humanos e animais. Coloniza o trato intestinal do hospedeiro já nas primeiras horas de vida, estabelecendo uma relação de simbiose, embora não esteja totalmente esclarecido seu papel na microbiota entérica (SUSSMAN, 1997; TRABULSI; ALTHERTUM, 2005). São mesófilas, crescendo de 18 a $44^{\circ} \mathrm{C}$, com temperatura ótima de crescimento de $37^{\circ} \mathrm{C}$. Seu tamanho varia de 1,1 a $1,5 \mu \mathrm{m}$ por 2 a $6 \mu \mathrm{m} \mathrm{e}$ produzem colônias com formas lisas ou rugosas em meio sólido, sendo possível ocorrer colônias mucóides (HIRSH; ZEE, 2003; FERREIRA; KNÖBL, 2009).

A maioria das amostras possui a capacidade de fermentar a lactose, entretanto algumas delas apresentam fermentação tardia (FERREIRA; KNÖBL, 2009). A produção de ácido e gás após a fermentação de maltose, glicose, lactose, manose, manitol, xilose, glicerol, ramnose, arabinose e sorbitol é também comum na maioria das amostras (KONEMAN et al., 2001; TORTORA; FUNKE; CASE, 2005).

Alguns sorotipos são considerados patogênicos, devido a diferentes fatores de virulência, podendo causar diversas manifestações clínicas, intestinais e extraintestinais em inúmeras espécies de animais (FERREIRA; KNÖBL, 2009).

E. coli possui muitos sorogrupos determinados por estruturas antigênicas (FERREIRA; KNÖBL, 2009):

- Antígenos capsulares (Kapel - "K") - de natureza proteica, podendo ser destruídos por aquecimento e com identificação realizada por testes de aglutinação; 
- Antígenos fimbriais (Fimbriae - "F") - de natureza proteica presentes na superfície bacteriana, capazes de reconhecer receptores específicos na superfície de células eucarióticas. Considerado um fator de virulência essencial para a aderência e colonização nos tecidos do hospedeiro;

- Antígenos somáticos (Ohne - "O") - corresponde ao lipopolissacarídeo (LPS) presente na parede celular sendo constituído de três frações: a) antígeno somático que é uma cadeia de polissacarídeo que se projeta para o espaço extracelular; b) o lipídeo A que é liberado na multiplicação bacteriana e atua na ativação de macrófagos e estimula a liberação de vários mediadores da inflamação e c) o core que é uma fração intermediária composta por oligossacarídeo que liga covalentemente o lipídeo $\mathrm{A}$ ao antígeno somático.

A tipagem sorológica tem sido largamente utilizada para se caracterizar $E$. coli. Entretanto, somente a sorologia não é adequada para a caracterização de cepas patogênicas de $E$. coli, sendo principalmente utilizados métodos moleculares para a identificação de genes de virulência associados a cada categoria da bactéria (NATARO; KAPER, 1998).

Este gênero bacteriano envolve linhagens causadoras de diversos quadros clínicos em seres humanos e animais como: $\operatorname{APEC~(E.~coli~patogênica~aviária),~}$ ETEC ( $E$. coli enterotoxigênica), EPEC (E. coli enteropatogênicas), EaggEC (E. coli enteroagregativa), EIEC (E. coli enteroinvasora), DAEC (E. coli de aderência difusa), STEC (E. coli produtora de toxina Shiga) e NMEC (E. coli de meningite neonatal) (KONEMAN et al., 2001; TRABULSI; ALTERTHUM, 2005;)

\subsection{COLIBACILOSE AVIÁRIA}

Escherichia coli patogênica aviária (APEC) está associada a infecções extraintestinais em galinhas, perus, patos e outras espécies aviárias causando a colibacilose aviária, termo utilizado para qualquer infecção localizada ou sistêmica responsável por significante morbidade e mortalidade (DHO-MOULIN; FAIRBROTHER, 1999; TUNTUFYE et al., 2012). 
Essa bactéria faz parte da microbiota de algumas espécies de aves, podendose encontrar mais de $10^{6}$ unidades formadoras de colônias (UFC) por grama de fezes (BARNES; VAILLANCOURT; GROSS, 2003). Coloniza e persiste no trato intestinal das aves, sendo que aproximadamente de 10 a 15\% dos coliformes são de sorotipos de E. coli potencialmente patogênicas. Esta localização proporciona uma excelente condição de disseminação da bactéria, pois uma vez eliminada pelas fezes a bactéria pode persistir no ambiente (BARNES; VAILLANCOURT; GROSS, 2003; DZIVA; STEVENS, 2008).

Em aves, as infecções por E. coli são consideradas multifatoriais, resultando da interação entre diversas variáveis como a presença de outros micro-organismos, manejo, instalações, alimentação e condição da ave. Na dependência da virulência da cepa bacteriana e destes fatores predisponentes as infecções podem ser localizadas nos sacos aéreos (aerossaculite) ou ocasionar pneumonia, pleuropneumonia, peritonite, colisepticemia, pericardite, celulite, onfalite, salpingite, doença respiratória crônica complicada (DRCC), sinovite, ooforite, artrite e osteomielite (BARNES; VAILLANCOURT; GROSS, 2003; FERREIRA; KNÖBL, 2009).

Os principais micro-organismos que predispõem ao surgimento da colibacilose nas aves são: Mycoplasma gallisepticum, vírus da Bronquite Infecciosa, vírus da Doença de Newcastle, vírus da Doença de Marek e vírus da Doença de Gumboro. Fatores como ventilação inadequada nos galpões, estresse, superpopulação, excesso de poeiras e gases também predispõe ao surgimento da doença (NAGARAJA, 1993; ANDREATTI FILHO, 2007; FERREIRA; KNÖBL, 2009).

Diferentes sorotipos de $E$. coli foram isolados de aves com colibacilose (MENÃO et al., 2002; DZIVA; STEVENS, 2008), mas além da sorotipificação também se utiliza para a caracterização da bactéria: a resistência a antibióticos, a detecção de toxinas, a presença de adesinas, a hemaglutinação, a adesão celular e a presença de plasmídeos (BARNES; VAILLANCOURT; GROSS, 2003). 


\subsection{FATORES DE VIRULÊNCIA}

Características bioquímicas e sensibilidade a antibióticos podem ser semelhantes em cepas de $E$. coli patogênicas e apatogênicas, sendo importante a caracterização de genes de virulência para se determinar a patogenicidade de uma amostra. Entretanto, é importante ressaltar que a função de vários genes de virulência não está ainda elucidada (BARNES; VAILLANCOURT; GROSS, 2003; DZIVA; STEVENS, 2008).

O surgimento de técnicas moleculares nos últimos anos tem propiciado um melhor entendimento dos mecanismos de patogenicidade das APEC. Houve a identificação de genes e a associação de alguns à patogenicidade e ou virulência em aves (SCHOULER et al., 2004; LI et al., 2005).

Fatores de virulência de APEC foram estudados e mostraram que algumas amostras possuíam mecanismos de escape em relação aos mecanismos de defesa do hospedeiro, além de outros genes de virulência que contribuíam para a patogenicidade da bactéria (EWERS et al., 2004; DZIVA; STEVENS, 2008; TUNTUFYE et al., 2012). Dentre estes fatores estão: os lipopolissacarídeos (LPS), o antígeno $\mathrm{O}$, a cápsula, as adesinas, os sistemas de secreção e os sistemas de captação de ferro (TUNTUFYE et al., 2012). A expressão de adesinas, a capacidade de resistir à ação microbicida do soro e a produção de sideróforos foram consideradas como fundamentais na patogenia da doença (FERREIRA; KNÖBL, 2009).

É importante ressaltar que os fatores de virulência podem ser transferidos através de plasmídeos de amostras não patogênicas para patogênicas (WOOLEY et al., 1998). 


\subsubsection{Adesinas}

A adesão da bactéria no epitélio do hospedeiro é considerada um fator importante para a infecção, pois permite a ligação e manutenção do contato com o tecido epitelial do hospedeiro (MOON, 1990; WOOLEY et al.,1998).

As adesinas, moléculas de natureza proteica que apresentam a estrutura de pili ou fímbrias, são fatores de colonização. Recobrem a superfície bacteriana e são capazes de se ligar a receptores específicos nas superfícies de células eucarióticas (NAVEH et al., 1984; HOEPELMAN; TUOMANEN, 1992; OFEK; DOYLE, 1993). São produzidas por algumas cepas de E. coli, sendo importantes para a adesão em células eucarióticas. Estão associadas à aderência em muco, colonização da traqueia, trato intestinal, e interação ao epitélio celular do pulmão (DOZOIS et al., 1997; EDELMAN et al., 2003).

Adesinas fimbriais foram inicialmente descritas em cepas de E. coli de infecções urinárias humanas (UTI) e posteriormente em cepas de APEC (KALLENIUS et al., 1980).

Em 1980, Arp e Jensen observaram que cepas virulentas e fimbriadas de $E$. coli foram mais persistentes em traqueia de perus do que cepas avirulentas e afimbriadas, sugerindo que as fímbrias poderiam ser um fator de virulência.

A fímbria tipo 1 está relacionada à adesão e colonização inicial no trato respiratório superior das aves, em cepas de APEC (MOON, 1990; WOOLEY et al.,1998). Esta propriedade pode ser inibida por anti-soros específicos e por Dmanose, um carboidrato que interage com um receptor celular presente nas membranas de células eucarióticas, sendo esta característica utilizada para a detecção desta fímbria na bactéria (NAKAZATO et al., 2009). A expressão da fímbria tipo 1 in vitro é modulada pelas condições de cultivo, sendo favorecida quando a bactéria é cultivada tanto a $20^{\circ} \mathrm{C}$ como a $37^{\circ} \mathrm{C}$, em baixas concentrações de oxigênio (ORSKOV; ORSKOV, 1983).

A fímbria $\mathrm{P}$ é codificada pelo operon pap que está localizado no cromossomo bacteriano, sendo que o gene papA codifica a maior proteína estrutural, o gene papl e papB são genes reguladores responsáveis pelo processo de variação de fase (LATHAM; STAMM, 1994; MOL; OUDEGA, 1996). Os genes papD, papH, papJ, papF e papK codificam proteínas relacionadas com a integridade do complexo 
fimbrial e o gene papE é responsável por codificar a extremidade estrutural da fímbria (MOL; OUDEGA, 1996). Subunidades complexas dobradas pelo chaperoneo (PapC) são orientadas para o usher, onde estas subunidades se polimerizam e se translocam através da membrana externa pelo poro usher (THANASSI; SAULINO; HULTGREN, 1998; WAKSMAN; HULTGREN, 2009).

Na patogenicidade das APECs o papel da fímbria $P$ ainda não está totalmente esclarecido. Estudos realizados in vivo sugeriram que estas adesinas seriam importantes nos últimos estágios da infecção, não no início do processo de colonização do trato respiratório superior (POURBAKHSH et al., 1997).

Na superfície celular de Escherichia coli e Salmonella enterica se encontram a fímbria curli, que são apêndices finos e enrolados. Estas são responsáveis pela ligação da bactéria a proteínas da matriz extracelular, e pela sobrevivência no meio ambiente, auxiliando na formação de biofilmes. A expressão dos genes que codificam esta fímbria é controlada por fatores ambientais como $\mathrm{pH}$, temperatura e osmolaridade (OLSEN; JONSSON; NORMARK, 1989).

\subsubsection{Hemaglutinina sensível à temperatura (TSH)}

A hemaglutinina sensível à temperatura é conhecida como uma proteína autotransportadora, pois utiliza um mecanismo próprio de transporte através da parede bacteriana (KOSTAKIOTI; STATHOPOULOS, 2004).

Um único gene é responsável pela expressão da proteína TSH que é sintetizada como uma proteína precursora de $140 \mathrm{KDa}$, é clivada em uma proteína secretada de $106 \mathrm{KDa}$ e uma proteína de 33KDa presente na membrana externa (STATHOPOULOS; PROVENCE; CURTISS,1999).

TSH é capaz de se aderir a hemácias, hemoglobina e proteínas da matriz extracelular como fibronectina e colágeno IV e possui atividade proteolítica contra a caseína. Dessa forma, apresenta propriedade proteolítica e de adesão (KOSTAKIOTI; STATHOPOULOS, 2004).

Estudos epidemiológicos indicaram que a presença do gene tsh em cepas de APEC, ocorria mais frequentemente em amostras patogênicas. Embora sua 
participação na patogenia da colibacilose aviária não esteja esclarecida, pois a deleção do gene tsh não foi capaz de inibir a reação de hemaglutinação (PROVENCE; CURTISS, 1994).

Maurer et al. (1998) analisando amostras de origem aviária obtiveram 46\% de amostras tsh positivas, 97\% csgA positivas e 100\% crl positivas. Estes resultados não foram confirmados por Campos et al. (2005) que demonstraram a presença de 25 e $50 \%$ do gene tsh em cepas de APEC isoladas de aves com septicemia e síndrome da cabeça inchada, respectivamente. No Brasil, Delicato et al. (2002) determinaram a ocorrência deste gene em 305 amostras de $E$. coli isoladas de aves, sendo $39,5 \%$ provenientes de aves com colisepticemia, $19 \%$ com celulite e $3,8 \%$ de amostras fecais.

Ewers et al. (2004) propuseram a utilização desse gene como um marcador molecular para se detectar cepas de APEC, em função da sua associação com APEC patogênica.

\subsubsection{Cápsula}

Consiste em uma estrutura externa composta de ácido $\mathrm{N}$-acetil murâmico que algumas cepas de E. coli possuem na sua superfície. Esta interage com a via clássica do complemento, conferindo resistência à bactéria, sendo o antígeno capsular $\mathrm{K} 1$ geralmente associado aos sorogrupos $\mathrm{O} 1, \mathrm{O} 2$ e outros sorogrupos não caracterizados (BARNES; VAILLANCOURT; GROSS, 2003).

Mellata et al. (2003) investigaram o papel dos seguintes fatores de virulência de cepas de E. coli de origem aviária, dos sorogrupos 01, 02 e 078: fímbria P, fimbria curli, aerobactina, lipopolissacarídeo (LPS), antígeno capsular (K1) e hemaglutinina sensível a temperatura (tsh) na interação com células fagocíticas. Os resultados indicaram que a presença de fímbria tipo 1 protegeu a bactéria contra efeitos bactericidas de células fagocíticas, especialmente de heterófilos, bem como o antígeno capsular K1 e a fímbria P evitaram a fagocitose.

Brée, Dho e Lafont (1989) analisaram amostras de E. coli do sorotipo $O 2$ e encontraram que a produção do antígeno $\mathrm{K} 1$ foi um determinante de virulência da 
bactéria. Pourbakhsh et al. (1997) também investigaram os fatores de virulência de três cepas de E. coli aviária por inoculação destas por via do saco aéreo. Os resultados sugeriram que a resistência à fagocitose poderia ser um importante mecanismo bacteriano para o desenvolvimento da colibacilose aviária e que cepas expressando o antígeno capsular $\mathrm{K} 1$ foram mais resistentes aos efeitos bactericidas do soro em comparação com as cepas que expressavam outros antígenos K.

\subsubsection{Alfa-hemolisina}

Cepas de E. coli isoladas de infecções extra-intestinais apresentaram mais frequentemente a produção de $\alpha$-hemolisina que as bactérias de origem fecal, sugerindo a importância desta como um fator de virulência. A hemolisina é secretada para o meio de cultura, como um peptídeo lábil, com $107 \mathrm{KDa}$, quando o crescimento bacteriano atinge a fase exponencial (MINISHEW et al., 1978; HOLLAND; BLIGHT; KENNY, 1990).

Para a síntese e secreção da $\alpha$-hemolisina são necessários quatro genes localizados em uma região contígua do DNA, denominados hlyA, hlyB, hlyC e hlyD. Para a secreção da hemolisina para o meio extracelular são necessários os produtos dos genes hlyB e hlyC (MACKMAN et al., 1986).

A ação da hemolisina se dá pela formação de poros de 1 a $2 \mu \mathrm{m}$ de diâmetro, na membrana do eritrócito, após a inserção de um monômero na camada lipídica. A consequente hemólise é uma alternativa para a obtenção de ferro pela bactéria (LEBEK; GRUENIG, 1985; BHAKDI et al., 1986). 


\subsubsection{Resistência sérica}

A resistência bacteriana ao complemento, mediada por estruturas da superfície bacteriana, foi associada com cepas de APEC (BARNES; VAILLANCOURT; GROSS, 2003; LYNNE et al., 2007).

Silveira, Fantinatti e Castro (1994) demonstraram que a presença de plasmídeo contendo o gene iss (aumento da sobrevivência no soro), não era suficiente para se determinar a capacidade patogênica de cepas de E. coli. Entretanto, esse gene foi considerado um marcador de virulência em APEC e foi encontrado na maioria das cepas patogênicas (PFAFF-MCDONOUGH et al., 2000). Johnson et al. (2008) descreveram o gene iss em um plasmídeo denominado Col V. Esse gene confere à bactéria resistência aos efeitos bactericidas do soro e é o mais prevalente em aves com colibacilose, atua pelo bloqueio do complexo de ataque à membrana do sistema complemento, que causa lise da célula.

Yang et al. (2004) analisaram 71 amostras de E. coli que apresentavam resistência à múltiplos antibióticos, encontraram positividade para o gene iss em 97\% amostras. Entretanto, a associação entre a presença do gene iss e a resistência a antimicrobianos não foi estabelecida (NOLAN et al., 2003; MCPEAKE; SMYTH; BALL, 2005).

\subsubsection{Sistema de aquisição de ferro}

A capacidade de bactérias patogênicas sequestrarem o íon ferro dos fluidos orgânicos é considerada primordial para a virulência. Em APEC esta característica foi associada à letalidade em pintinhos de um dia de idade (DZIVA; STEVENS, 2008).

O íon ferro é encontrado em grandes quantidades nos fluídos corporais e tecidos. Em condições fisiológicas está ligado à glicoproteínas ou apresenta-se em forma insolúvel, constituindo um mecanismo de defesa do organismo, pois impede o 
desenvolvimento de micro-organismos que necessitam deste elemento. Desta forma, as bactérias dependem da produção de complexos inorgânicos com afinidade pelo ion ferro (sideróforos) e da síntese de proteínas de membrana que atuem como receptoras para o complexo sideróforo-ferro (NEILANDS, 1981).

Bactérias patogênicas Gram negativas possuem esses mecanismos para a aquisição de ferro. O sistema melhor caracterizado é o da aerobactina, que em amostras de $E$. coli pode ser codificado por genes cromossomais ou plasmideais. Este sistema compreende genes para a síntese de aerobactina (iuc) e do receptor para a aerobactina ligada ao íon ferro (iut), para a captação deste (LAFONT et al., 1987).

Além da aerobactina, existem outros sistemas de aquisição e transporte do íon ferro presentes no plasmídeo ColV, que inclui o sistema de transporte de ferro sitABC (DZIVA; STEVENS, 2008).

\subsection{RESISTÊNCIA A ANTIMICROBIANOS}

A história da humanidade é marcada pela luta constante contra os microorganismos que causam diversas infecções e doenças. A partir do século XX 0 descobrimento da penicilina surgiu como a primeira grande arma nesta batalha. $O$ desenvolvimento de outros antimicrobianos trouxe uma euforia aos profissionais de saúde. Entretanto, com o uso indiscriminado destes produtos, rapidamente houve a resposta das bactérias, com o desenvolvimento de várias formas de resistência (TENOVER, 2006).

A resistência bacteriana a antimicrobianos continua aumentando muito, principalmente nas últimas décadas e tornou-se um problema de proporções mundiais (ROSSI; ANDREAZZI, 2005). O uso intensivo de antibióticos como promotores de crescimento em animais induziu uma grande seleção de bactérias resistentes e a fixação destas características nas populações, com impacto tanto em saúde pública como animal, pois algumas classes desses produtos normalmente utilizados para o tratamento de infecções humanas são também utilizados como promotores de crescimento e tratamento em animais (WEGENER et al., 1999). 
Aproximadamente $8.164 .662 \mathrm{Kg}$ de antibióticos foram utilizados, por ano, em criações animais, sendo que $70 \%$ foram utilizados como promotor de crescimento, em contraste com $1.363 .636 \mathrm{Kg}$ utilizados em medicina humana (ROE; PILLAI, 2003).

Os micro-organismos geralmente resistem a ação de antibióticos por interferência com os requisitos necessários para a ligação do fármaco ao seu local de destino, destruindo ou alterando a integridade conformacional da droga ou prevenindo que o medicamento atinja uma concentração efetiva no seu local de ação, essa resistência bacteriana pode ser plasmideal ou cromossomal (Quadro 1) (CLARKE, 2006).

Em relação a E. coli há uma grande preocupação, pois algumas cepas foram capazes de adquirir e transferir genes de resistência bacteriana, o que dificultou o tratamento (JOUINI et al., 2009; KOO; WOO, 2011; SUNDE; NORSTRÖM, 2006).

Zanata et al. (2004) analisaram a sensibilidade a antimicrobianos em 27 amostras de E. coli isoladas de aves com colibacilose da região centro-oeste do Estado de São Paulo. Obtiveram como resultado a resistência das amostras testadas frente a quase todas as drogas, sendo que as amostras não apresentaram resistência somente à ciprofloxacina, a norfloxacina e a gentamicina.

Miles, McLaughlin e Brown (2006) analisaram 82 amostras de E. coli isoladas de frangos de corte, urina e fezes de pacientes hospitalizados para se determinar a suscetibilidade destas bactérias frente a 11 antimicrobianos. Encontraram 82,4\% de resistência à tetraciclina nas amostras isoladas de aves comparadas a 43,8\% nas amostras humanas. Além disso, as amostras aviárias apresentaram maior resistência à kanamicina e ao ácido nalidíxico, enquanto as de humanos foram mais resistentes ao cloranfenicol e a gentamicina.

Obeng et al. (2012) analisaram 251 amostras de E. coli de fezes de frangos de criações intensivas e frangos, poedeiras de vida livre na Austrália. Encontraram $40,6 \%$ e $26,7 \%$ de resistência à tetraciclina e à ampicilina respectivamente. Também observaram resistência à sulfa-trimetropin (12,4\%), estreptomicina (10,8\%), espectiomicina $(9,6 \%)$, neomicina $(6,0 \%)$ e florfenicol $(2,0 \%)$, mas nenhuma resistência foi observada à gentamicina, ciprofloxacina e ceftiofur. 
Quadro 1 - Mecanismos de resistência entre bactérias e suas bases genéticas

\begin{tabular}{|c|c|c|}
\hline Mecanismo de resistência & Classe de antibiótico & Genética \\
\hline $\begin{array}{c}\text { Inibição enzimática } \\
\beta \text {-lactamases }\end{array}$ & & \\
\hline $\begin{array}{l}\text { - Grupo } 1 \text { - cefalosporina } \\
\text { (hidrólise não inibida por } \\
\text { CA) }\end{array}$ & $\beta$-lactamase & Cromossomal \\
\hline $\begin{array}{l}\text { - Grupo 2a - penicilinases } \\
\text { inibidas por CA }\end{array}$ & $\beta$-lactamase & Plasmideal \\
\hline $\begin{array}{l}\text { - Grupo 2bN - amplo } \\
\text { escpectro não inibido por } \\
\text { CA }\end{array}$ & $\beta$-lactamase & Plasmideal e cromossomal \\
\hline 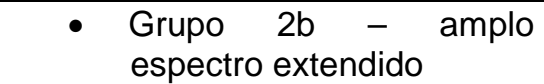 & $\beta$-lactamase & Plasmideal \\
\hline $\begin{array}{l}\text { - Grupo 2c } \\
\text { carbenicilinases, } \\
\text { oxicilinases }\end{array}$ & $\beta$-lactamase & Plasmideal e cromossomal \\
\hline $\begin{array}{llr}\text { - } & \text { Grupo } & \text { - } \\
\text { cefalosporinas } & \text { inibidas } \\
\text { por CA } & \\
\end{array}$ & $\beta$-lactamase & Plasmideal e cromossomal \\
\hline - $\quad$ Grupo 3 - metaloenzimas & $\beta$-lactamase & Plasmideal e cromossomal \\
\hline $\begin{array}{l}\text { Grupo } 4 \text { - penicilinases } \\
\text { não inibidas por CA } \\
\text { Acetiltransferases, } \\
\text { adeniltransferases, } \\
\text { fosfotransferases } \\
\text { Cloranfenicol } \\
\text { acetiltransferases } \\
\text { Esterases, } \\
\text { fosfotranferases } \\
\text { Alteração de } \\
\text { permeabilidade } \\
\text { Canais de porinas } \\
\text { Efluxo de drogas }\end{array}$ & $\begin{array}{c}\text { Aminoglicosídeos } \\
\text { Cloranfenicol } \\
\text { Macrolídeos, estreptograminas } \\
\text { B-lactamases, aminoglicosídeos } \\
\text { e macrolídeos } \\
\text { B-lactamases e carbapenems } \\
\text { Quinolonas, tetraciclinas, } \\
\text { cloranfenicol e } \beta \text {-lactamases }\end{array}$ & $\begin{array}{c}\text { Plasmideal e cromossomal } \\
\text { Plasmideal, exceto } \\
\text { Enterococcus faecium } \\
\text { (cromossomal) } \\
\text { Plasmideal, cromossomal } \\
\text { Plasmideal } \\
\text { Cromossomal } \\
\text { Cromossomal } \\
\text { Plasmideal, cromossomal }\end{array}$ \\
\hline $\begin{array}{l}\text { Alteração de local alvo } \\
\text { Proteína de ligação de penicilina } \\
\text { alterada } \\
\text { Oligopeptideo da parede celular } \\
\text { alterada } \\
\text { Alvo ribossomal alterado } \\
\text { - Inibição competitiva pelo } \\
\text { excesso de produção de } \\
\text { ácido p-aminobenzóico } \\
\text { ou sintetase } \\
\text { dihidropteroato alteradas } \\
\text { Utilização de } \\
\text { requerimento alternativo } \\
\text { de crescimento }\end{array}$ & $\begin{array}{c}\text { B-lactamases } \\
\text { Glicopeptídeo } \\
\text { Tetraciclinas, macrolídeos, } \\
\text { aminoglicosídeos, } \\
\text { estreptograminas, oxazolidinone }\end{array}$ & $\begin{array}{c}\text { Plasmideal em S., aureus, } \\
\text { genes mosaico em } \\
\text { Streptococcus pneumoniae } \\
\text { penicilina resistente vanA e } \\
\text { vanB - transferível plasmídio; } \\
\text { vanC - plasmídio }\end{array}$ \\
\hline
\end{tabular}

CA - ácido clavulônico

Fonte: Adaptado de KHARDORI, 2006 


\subsection{EPIDEMIOLOGIA}

E. coli é uma bactéria encontrada na microbiota entérica, na maioria dos mamíferos e aves, com a colonização do intestino iniciando-se logo após o nascimento. Sua presença em água e alimentos é um indicador de contaminação fecal (FRANCO; LANDGRAF, 2006).

A colibacilose aviária tem distribuição cosmopolita e as aves excretam a bactéria de forma contínua pelas fezes, o que faz com que esta permaneça por longos períodos nas criações, contaminando água e alimentos que poderão ser vias de transmissão da doença. Aves silvestres e roedores também podem funcionar como reservatório do agente (BARNES; VAILLANCOURT; GROSS, 2003).

A via natural de infecção não está claramente definida, entretanto o trato respiratório parece ser uma das mais significantes portas de entrada, com posterior colonização da traqueia e disseminação para sacos aéreos e tecidos adjacentes (DZIVA; STEVENS, 2008).

A colibacilose é multifatorial, resultante da interação entre a bactéria, o meio ambiente e o hospedeiro, sendo que apenas amostras patogênicas podem causar a doença nas aves, ou seja, as que apresentem fatores de virulência (FERREIRA; REVOLLEDO; FERREIRA, 2009).

São considerados fatores predisponentes para a colibacilose infecções por Mycoplasma, doença de Newcastle, coriza infecciosa das galinhas, pneumovirose, bronquite infecciosa das galinhas, doenças imunossopressoras como doença de Gumboro, além de condições de ventilação inadequada e estresse (BARNES; VAILLANCOURT; GROSS, 2003; FERREIRA; KNÖBL, 2009).

Normalmente as aves mais jovens (entre 4 e 9 semanas de idade) são mais susceptíveis aos quadros respiratórios e nas aves adultas observa-se a ocorrência de salpingite (FERREIRA; REVOLLEDO; FERREIRA, 2009). 


\subsection{MUTAGÊNESE BACTERIANA}

Mutações são alterações na estrutura química ou física do DNA, que podem ser causadas por agentes físicos ou químicos, ocasionando variações fenotípicas ou variações detectadas por processos bioquímicos ou biofísicos. Podem ser espontâneas, ocasionadas por erro na replicação do DNA por exposição do microorganismo a influências extracelulares do meio onde o mesmo se encontra, ou induzida por exposição proposital a um agente genotóxico (TRABULSI; ALTERTHUM, 2005).

A taxa de mutação bacteriana frente a um mutagênico específico depende da natureza da base no extremo $5^{\prime}$ do DNA, sendo esta taxa de $1 \times 10^{-4}$ ou maior. A estimativa é de um (01) erro a cada mil a dez mil replicações para $E$. coli que possui um cromossomo de 4,6 $\times 10^{6}$ pares de bases. Nesta espécie foram detectados genes suscetíveis à mutação, como por exemplo, o gene que produz a RNA polimerase termolábil (TORTORA; FUNKE; CASE, 2005; TRABULSI; ALTERTHUM, 2005).

Pesquisas com substâncias mutagênicas indicaram a possibilidade das mutações induzirem a uma diminuição na virulência de algumas bactérias, conservando sua capacidade imunogênica. Uma cepa J5 de E. coli O78 com mutação no gene para a endotoxina, com uma endotoxina incompleta na sua parede celular, foi segura e eficaz na proteção de pintos após a utilização como vacina e desafio com cepa homóloga (ABDUL AZIZ; EL SOKHON, 1998).

Nagano, Kitaha e Nagai (2012) produziram uma vacina viva atenuada com uma cepa aviária patogênica de Escherichia coli O78, por deleção no gene crp, consequentemente sem a capacidade de produzir indol. A cepa com mutação não possuía os genes tsh, iss, cvaA e papC e era suscetível a vários antimicrobianos com a exceção de ácido nalidíxico. Após a vacinação por via spray, ocular e in ovo, ocorreu uma diminuição do escore de lesões e redução de mortalidade e manifestações clínicas, após o desafio, por via intravenosa, com cepa homóloga. 


\subsection{VACINAS}

Diante dos vários problemas sanitários decorrentes da criação de aves industriais, a vacinação é uma ferramenta imprescindível para a manutenção da saúde dos animais. Os principais tipos de vacinas utilizadas para as aves são as inativadas, onde os micro-organismos são mortos por algum processo ou produto químico e as atenuadas, cujos micro-organismos perdem ou tem sua virulência diminuída (MENÃO, 2008).

Nas últimas décadas, vários tipos dessas vacinas foram testadas em aves comerciais para se controlar a septicemia e doenças respiratórias causadas por APEC (DHO-MOULIN; FAIRBROTHER, 1999; YAGUCHI et al., 2009; LYNNE et al., 2012). Os sorotipos mais utilizados para a produção destas foram o O2 e o O78, mais comumente encontrados em casos de colibacilose aviária. Estas vacinas promovem a proteção contras sorotipos homólogos, entretanto, não há proteção contra as cepas heterólogas (MENÃO, et al. 2002; BARNES; VAILLANCOURT; GROSS, 2003).

Melamed, Leitner e Heller (1991) conseguiram obter melhor proteção com as vacinas inativadas quando utilizaram as cepas dos sorotipos $\mathrm{O} 2$ e $\mathrm{O} 78$ de E. coli e o método de inativação por ultra-som seguido pelo processo de radiação, quando comparado ao método de inativação por formalina e irradiação. Correlacionaram o grau de proteção conferido com a concentração sérica de anticorpos. Estas vacinas foram utilizadas para a vacinação de matrizes com o intuito de proporcionar uma imunidade passiva na progênie contra as cepas homólogas, por até 21 dias de idade (HELLER et al., 1990).

Gomis et al. (2007) testaram a citosina-guanina-diestér (CpG) como adjuvante para potencializar a resposta imune em uma vacina inativada oleosa contra $E$. coli em aves. Vacinaram dois grupos de aves com e sem o adjuvante, com duas doses, e 10 dias após realizaram o desafio com cepa homóloga e virulenta. Encontraram no grupo vacinado com CpG títulos de lgG maiores, significativamente menor mortalidade das aves e menor isolamento de bactérias dos órgãos internos comparados ao grupo vacinado sem $\mathrm{CpG}$.

As vacinas inativadas necessitam de adjuvantes para potencializar $e$ prolongar o período de resposta imune, consequentemente mais onerosas e podem 
causar efeitos colaterais nas aves. Dessa forma, não devem ser utilizadas em frangos de corte, portanto, as vacinas atenuadas tornam-se uma alternativa viável neste tipo de criação (YUNIS et al., 2000; PEIGHAMBARI et al., 2002; GREGERSEN et al., 2010).

Fromer et al. (1994) demonstraram que uma vacina preparada com uma cepa não patogênica de $E$. coli induziu imunidade e proteção contra cepas homólogas e heterólogas, em frangos vacinados com 14 e 21 dias de idade.

Vacinas recombinantes também estão sendo testadas para a proteção contra a colibacilose aviária. Lynne et al. (2012) testaram uma vacina recombinante no gene iss de E. coli e demonstraram que esta conferia maior proteção às aves após o desafio quando comparadas às aves do grupo controle.

Os sorotipos $\mathrm{O} 1, \mathrm{O} 2$ e $\mathrm{O} 78$ foram os mais frequentemente encontrados em casos de colibacilose aviária na maioria dos países, apesar de ocorrer variação geográfica. Em consequência, estes resultados direcionam para a utilização destes sorotipos na produção de vacinas (BARNES; VAILLANCOURT; GROSS, 2003). 
OBJETIVOS 


\section{OBJETIVOS}

Os objetivos estão divididos em geral e específicos, os quais seguem discriminados abaixo.

\subsection{GERAL}

- Caracterizar as cepas pré-selecionadas (selvagens ou com mutações) com respeito à patogenicidade e caracterização genotípica.

\subsection{ESPECÍFICOS}

- Caracterizar as cepas em relação à suscetibilidade a antimicrobianos.

- Induzir resistência a rifampicina, a estreptomicina e ao ácido nalidíxico.

- Produzir E. coli com mutações pela exposição a substância mutagênica;

- Comparar o genótipo, ou seja, o perfil de genes de virulência e a suscetibilidade a antimicrobianos, de cepas de E. coli selvagens ou com mutações;

- Comparar a patogenicidade de cepas de E. coli selvagens com as cepas com mutações em pintinhos infectados, por via do saco aéreo;

- Comparar as lesões induzidas em pintinhos inoculados com cepas selvagens ou com mutações. 
MATERIAL E MÉTODOS 


\section{MATERIAL E MÉTODOS}

\subsection{AMOSTRAS BACTERIANAS}

Foram selecionadas nove (09) amostras de E. coli patogênicas de diferentes Estados brasileiros, pertencentes a coleção de cultura do Laboratório de Ornitopatologia da Universidade de São Paulo, isoladas de aves que apresentaram as seguintes enfermidades: onfalite, salpingite, doença respiratória crônica complicada e colisepticemia. As características previamente estudadas e consideradas nesta seleção foram: patogenicidade, genes de virulência e sensibilidade a antimicrobianos.

Todas as amostras selecionadas foram cultivadas em ágar MacConkey por 24 horas a $37^{\circ} \mathrm{C}$. O quadro 2 apresenta o número, sorotipo, origem e o órgão de isolamento das amostras pertencentes à coleção de cultura do laboratório de Ornitopatologia/ FMVZ/USP.

Uma colônia de cada amostra cultivada em ágar MacConkey foi transferida para o meio Luria Bertani (LB) e incubada a $37^{\circ} \mathrm{C}$ por 24 horas. Uma alíquota de $200 \mu \mathrm{L}$ de cada cultura foi utilizada para a extração de DNA. 
Quadro 2 - Identificação das amostras de E coli, sorotipo, origem e órgão de isolamento

\begin{tabular}{|c|c|c|c|c|}
\hline Amostra & Identificação & Sorotipo & Origem & $\begin{array}{c}\text { Órgão de } \\
\text { isolamento }\end{array}$ \\
\hline Escherichia coli & EC 269 & O2 & São Paulo & Fígado \\
\hline Escherichia coli & EC 341 & O119 & São Paulo & Saco aéreo \\
\hline Escherichia coli & EC 713 & NT & São Paulo & Saco aéreo \\
\hline Escherichia coli & EC 775 & O78 & São Paulo & Fígado \\
\hline Escherichia coli & EC 1299 & O78 & $\begin{array}{c}\text { Santa } \\
\text { Catarina }\end{array}$ & Fígado \\
\hline Escherichia coli & EC 1696 & O78 & São Paulo & Saco aéreo \\
\hline Escherichia coli & EC 1708 & O88 & São Paulo & Saco aéreo \\
\hline Escherichia coli & EC 1869 & O112 & São Paulo & Intestino \\
\hline Escherichia coli & EC 1889 & NT & São Paulo & Intestino \\
\hline
\end{tabular}

\subsection{EXTRAÇÃO DO DNA BACTERIANO E REAÇÃO EM CADEIA PELA POLIMERASE (PCR)}

\subsubsection{Determinação dos fatores de virulência}

Diferentes pares de primers foram utilizados na pesquisa dos genes de virulência. O quadro 3 apresenta as informações sobre os genes pesquisados, a sequência dos oligonucleotídeos, o tamanho dos fragmentos e as referências bibliográficas utilizadas.

A extração de DNA foi realizada segundo a metodologia descrita por Boom et al. (1990). A amplificação foi realizada em termociclador. A mistura para a amplificação foi constituída por Tris- $\mathrm{HCl} 10 \mathrm{mM}(\mathrm{pH} 8,3), \mathrm{KCl} 50 \mathrm{mM}, \mathrm{MgCl}_{2}$ $1,5 \mathrm{mM}$, gelatina $0,001 \%$ (água/volume), trifosfatos de desoxinucleotídeos $200 \mu \mathrm{M}$, 
pares de primers, e Taq DNA polimerase 0,5 U em um volume final de $25 \mu \mathrm{l}$. Os produtos da amplificação foram separados por eletroforese em um gel de agarose $1,5 \%$ e examinados após coloração com SyBR® Safe DNA gel stain (Invitrogen). 0 marcador de peso molecular utilizado foi o DNA ladder (Invitrogen) de 100 pb.

Quadro 3 - Genes de virulência pesquisados pela reação de polimerase em cadeia

\begin{tabular}{|c|c|c|}
\hline Genes & Pares de primers $\left(5^{\prime}-3^{\prime}\right)$ & Referência \\
\hline$i u c D$ & $\begin{array}{l}\text { TACCGGATTGTCATATGCAGACCGT } \\
\text { AATATCTTCCTCCAGTCCGGAGAAG }\end{array}$ & YAMAMOTO et al., 1995 \\
\hline tsh & $\begin{array}{l}\text { GGGAAATGACCTGAATGCTGG } \\
\text { CCGCTCATCAGTCAGTACCAC }\end{array}$ & MAURER et al., 1998 \\
\hline iss & $\begin{array}{l}\text { GTGGCGAAAACTAGTAAAACAGC } \\
\text { CGCCTCGGGGTGGATAA }\end{array}$ & HORNE et al., 2000 \\
\hline papC & $\begin{array}{l}\text { TGATATCACGCAGTCAGTAGC } \\
\text { CCGGCCATATTCACATAAC }\end{array}$ & JANBEN et al., 2001 \\
\hline irp2 & $\begin{array}{l}\text { AAGGATTCGCTGTTACCGGAC } \\
\text { TCGTCGGGCAGCGTTTCTTCT }\end{array}$ & SCHUBERT et al., 1998 \\
\hline ast $A$ & $\begin{array}{l}\text { TGCCATCAACACAGTATATCC } \\
\text { TAGGATCCTCAGGTCGCGAGTGACGGC }\end{array}$ & $\begin{array}{c}\text { YAMAMOTO e ECHEVERRIA, } \\
1996\end{array}$ \\
\hline cvi/cva & $\begin{array}{l}\text { TCCAAGCGGACCCCTTATAG } \\
\text { CGCAGCATAGTTCCATGCT }\end{array}$ & EWERS et al., 2007 \\
\hline sfa & $\begin{array}{l}\text { CTCCGGAGAACTGGGTGCATCTTAC } \\
\text { CGGAGGAGTAATTACAAACCTGGCA }\end{array}$ & YAMAMOTO et al., 1995 \\
\hline hly & $\begin{array}{l}\text { AACAAGGATAAGCACTGTTCTGGCT } \\
\text { ACCATATAAGCGGTCATTCCCGTCA }\end{array}$ & YAMAMOTO et al., 1995 \\
\hline neuS & $\begin{array}{l}\text { TATAATTAGTAACCTGGGGC } \\
\text { GGCGCTAATGAATAAGACTG }\end{array}$ & TSUKAMOTO, 1997 \\
\hline$c n f$ & $\begin{array}{l}\text { AAGATGGAGTTTCCTATGCAGGAG } \\
\text { CATTCAGAGTCCTGCCCTCATTATT }\end{array}$ & YAMAMOTO et al., 1995 \\
\hline vat & $\begin{array}{l}\text { TCCTGGGACATAATGGTCAG } \\
\text { GTGTCAGAACGGAATTGTC }\end{array}$ & EWERS et al. 2004 \\
\hline
\end{tabular}

\subsection{TESTES DE SUSCETIBILIDADE A ANTIMICROBIANOS}

Dois diferentes métodos diagnósticos foram utilizados nas cepas de $E$. coli para a seleção de amostras para a indução de resistência à antimicrobianos. 


\subsubsection{Concentração inibitória mínima}

Utilizou-se o teste de microdiluição comercial Avipro plate (Lohmann Animal Health \& Co. KG) que quantifica in vitro a atividade de um antimicrobiano frente a bactérias isoladas de aves. Cada cavidade é preparada com as diferentes concentrações dos seguintes antibióticos: amoxacilina, colistina, doxiciclina, enrofloxacina, eritromicina, espectinomicina, estreptomicina, lincomicina, neomicina, oxacilina, penicilina, rifampicina, tiamulina, tilmicosin, tetraciclina, lincomicinaespectinomicina e trimetropin-sulfametazona.

Uma colônia da cada cepa a ser testada de E. coli, semeada em ágar MacConkey e mantida a $37^{\circ} \mathrm{C}$ por 24 horas, foi inoculada em $5 \mathrm{~mL}$ de solução de $\mathrm{NaCl}$ 0,9\%, homogeneizada. A turbidez foi ajustada pela escala de MacFarland a 0,5 $\left(1,5 \times 10^{8} \mathrm{UFC} / \mathrm{mL}\right)$ com o auxílio de um espectrofotômetro, em comprimento de onde de $620 \mathrm{~nm}$. A amostra ATCC 25922 de Escherichia coli foi utilizada como controle positivo.

Uma alíquota de $50 \mu \mathrm{L}$ da suspensão bacteriana foi transferida para $11 \mathrm{~mL}$ de meio Muller-Hinton, homogeneizada e $100 \mu \mathrm{L}$ transferidos para cada cavidade da placa, antes de 30 minutos. A placa foi incubada a $37^{\circ} \mathrm{C}$ por 18 a 24 horas.

A leitura visual foi realizada pela presença ou ausência de crescimento bacteriano e as bactérias foram classificadas como: sensível (S), parcialmente sensível (PS) ou resistente (R).

\subsubsection{Técnica de difusão em disco}

Os perfis de sensibilidade a antimicrobianos dos isolados foram analisados por meio da técnica de difusão em ágar, pela técnica de Bauer-Kirby (1966), seguindo as recomendações do CLSI (Clinical and Laboratory Standards Institute, 2009).

Foram utilizados os seguinte antibióticos: ácido nalidíxico (30 $\mu \mathrm{g})$, ampicilina $(10 \mu \mathrm{g})$, cloranfenicol $(30 \mu \mathrm{g})$, ciprofloxacina $(5 \mu \mathrm{g})$, doxiciclina $(30 \mu \mathrm{g})$, enrofloxacina 
$(10 \mu \mathrm{g})$, eritromicina $(15 \mu \mathrm{g})$, estreptomicina $(10 \mu \mathrm{g})$, florfenicol $(30 \mu \mathrm{g})$, gentamicina $(10 \mu \mathrm{g})$, tetraciclina $(30 \mu \mathrm{g})$ e sulfa-trimetropin $(30 \mu \mathrm{g})$.

A cepa ATCC 25.922 foi utilizada como controle positivo.

\subsubsection{Indução de resistência a antimicrobianos}

Todas as cepas bacterianas foram semeadas em ágar MacConkey e incubadas a $37^{\circ} \mathrm{C}$ por 24 horas. Uma colônia de cada cepa foi selecionada e semeada em placas com ágar nutriente, com concentrações crescentes (de 10 a 800 $\mathrm{mg} / \mathrm{L}$ ) de ácido nalidíxico, estreptomicina e rifampicina. A placa foi incubada por 24 horas a $37^{\circ} \mathrm{C}$. O quadro 4 mostra a cepa de $E$. coli estudada e a resistência inicial ao antibiótico utilizado.

A estabilidade da resistência foi testada por 20 passagens sucessivas, em ágar nutriente e posterior semeadura em ágar nutriente com $800 \mu \mathrm{g} / \mathrm{mL}$ de antibiótico.

Quadro 4 - Cepas de E. coli e antibióticos utilizados para a indução de resistência

\begin{tabular}{|c|c|}
\hline Cepa & Antibiótico \\
\hline EC 269 & Rifampicina \\
\hline EC 341 & Rifampicina \\
\hline EC 713 & Rifampicina \\
\hline EC 775 & Rifampicina \\
\hline EC 1299 & Rifampicina \\
\hline EC 1696 & Ácido nalidíxico \\
\hline EC 1708 & Estreptomicina \\
\hline EC 1869 & Rifampicina \\
\hline EC 1889 & Estreptomicina \\
\hline
\end{tabular}




\subsection{INDUÇÃO DE MUTAÇÃO POR SUBSTÂNCIA MUTAGÊNICA}

Uma colônia de cada cepa de E. coli semeada em ágar MacConkey e mantida a $37^{\circ} \mathrm{C}$ por 24 horas, foi inoculada em $2 \mathrm{~mL}$ de meio Luria Bertani (LB) e incubada a $37^{\circ} \mathrm{C}$ por 24 horas.

A esta suspensão bacteriana se adicionou $100 \mathrm{~mL}$ de PBS $0,1 \mathrm{M}, \mathrm{pH} 7,4$ contendo a substância mutagênica (o nome da substância não foi citado devido ao requerimento de patente USP), incubando-se a $37^{\circ} \mathrm{C}$ por seis $(06)$ horas. Realizouse diluição seriada, na base 10, de cada amostra em zero, três e seis horas para se avaliar a mortalidade bacteriana.

Após seis (06) horas, semeou-se uma alíquota de cada amostra em ágar MacConkey, e as placas foram mantidas a $37^{\circ} \mathrm{C}$ por 24 horas, para o isolamento de colônias bacterianas.

\subsection{POLIMORFISMO DO COMPRIMENTO DE FRAGMENTOS AMPLIFICADOS (AFLP)}

As amostras foram submetidas à extração do DNA genômico segundo as descrições de Boom et al. (1990). As amostras de DNA foram armazenadas a $-20^{\circ} \mathrm{C}$. O AFLP foi realizado com a endonuclease de restrição Hind III, segundo o protocolo descrito por McLauchlin et al. (2000).

Para a clivagem do DNA bacteriano, $4 \mu \mathrm{g}$ de DNA foram adicionados a um microtubo contendo $24 \mathrm{U}$ de Hind III, tampão da enzima (1X) e água ultra pura estéril para um volume final de $20 \mu \mathrm{L}$. O tubo foi incubado a $37^{\circ} \mathrm{C}$ por 12 a 18 horas.

Uma alíquota de $5 \mu \mathrm{L}$ do DNA clivado foi adicionada a um microtubo contendo $0,2 \mu \mathrm{g}$ dos adaptadores $\mathrm{ADH} 1$ e $\mathrm{ADH} 2,1 \mathrm{U}$ de T4 DNA ligase, tampão da enzima para esta reação e água ultra pura estéril para um volume final de $20 \mu \mathrm{L}$. Esta reação foi incubada à temperatura ambiente por três (03) horas. O DNA ligado foi aquecido a $80^{\circ} \mathrm{C}$ por 10 minutos. A PCR foi realizada utilizando-se $2 \mu \mathrm{L}$ do DNA ligado diluído, 2,5 $\mathrm{mM}$ de $\mathrm{MgCl}_{2}, 300 \mathrm{ng}$ do "primer" (HI-G), $1 \mathrm{U}$ de Taq DNA polimerase, $1 \mathrm{X}$ tampão de $\mathrm{PCR}$ e água ultra pura estéril para um volume final de 50 
$\mu \mathrm{L}$. A reação foi submetida à desnaturação a $94^{\circ} \mathrm{C}$ por 4 minutos seguidos por 35 ciclos de 1 minuto a $94^{\circ} \mathrm{C}, 1$ minuto a $60^{\circ} \mathrm{C}$ e 2,5 minutos a $72^{\circ} \mathrm{C}$.

Os produtos amplificados foram submetidos à eletroforese a $28 \mathrm{~V}$ por 24 horas em gel de agarose $2 \%$, e em seguida corado com Gel Red® (Biotium) por 30 minutos, sob agitação. O gel foi então fotografado através de luz ultra-violeta em um sistema de foto documentação convencional. Os fragmentos foram identificados por meio de um marcador de peso molecular de 100 pb (Invitrogen).

\subsection{TESTE DE PATOGENICIDADE EM PINTINHOS DE UM DIA}

\subsubsection{Aves}

Foram utilizados pintinhos livres de patógenos específicos (SPF), com um dia de idade. As aves foram alimentadas com ração comercial, água ad libidum e alojadas em bateria de $1,7 \mathrm{~m}^{2}$. As amostras foram estudadas individualmente, em grupos de 10 aves, para se evitar a contaminação cruzada entre as amostras de E. coli.

\subsubsection{Delineamento experimental}

As aves $S P F$ foram divididas em 20 grupos $(n=10)$. Estas receberam $0,1 \mathrm{~mL}$ de E. coli selvagem ou com mutação por via do saco aéreo direito. As aves do grupo 19 receberam meio Luria Bertani (LB) (C1) e aquelas do grupo 20, nenhuma inoculação (C2). $O$ quadro 5 descreve estes grupos. 
Quadro 5 - Grupos de aves e cepas de E. coli utilizadas para a inoculação das aves

\begin{tabular}{|c|c|}
\hline Grupos & Cepa \\
\hline T1 & EC 269 S \\
\hline T2 & EC 269 M \\
\hline T3 & EC 341 S \\
\hline T4 & EC 341 M \\
\hline T5 & EC 713 S \\
\hline T6 & EC 713 M \\
\hline T7 & EC 775 S \\
\hline T8 & EC 775 M \\
\hline T9 & EC 1299 S \\
\hline T10 & EC 1299 M \\
\hline T11 & EC 1669 S \\
\hline T12 & EC 1699 M \\
\hline T13 & EC 1708 S \\
\hline T14 & EC 1708 M \\
\hline T15 & EC 1869 S \\
\hline T16 & EC 1869 M \\
\hline T17 & EC 1889 S \\
\hline T18 & EC 1889 M \\
\hline T19 & Controle 1 (C1) \\
\hline T20 & Controle 2 (C2) \\
\hline
\end{tabular}

\subsubsection{Teste de patogenicidade}

O teste de patogenicidade foi realizado através da inoculação de $0,1 \mathrm{~mL}$ de cultura bacteriana, padronizada por contagem por diluição seriada em de $2 \times 10^{5}$ a $1,2 \times 10^{7}$ unidades formadoras de colônias por mililitro (UFC/mL) (Quadro 6), no saco aéreo de pintinhos de um dia de idade, como descrito por Dho e Lafont (1982). Para o preparo do inoculo foi semeada uma (01) colônia de cada cepa bacteriana em $5 \mathrm{~mL}$ de caldo BHI (Difco, Detroit, MI), incubando-se a cultura por 12 horas a $37^{\circ} \mathrm{C}$.

A mortalidade foi acompanhada com observações de 12 em 12 horas por dez dias e de acordo com o índice de mortalidade, as amostras foram classificadas em alta (mortalidade > 80\%), intermediária (mortalidade $\geq 50 \%$ e $\leq 80 \%$ ), baixa patogenicidade (mortalidade < 50\%) e não patogênica (mortalidade zero). Após este período, as aves foram sacrificadas em câmara de $\mathrm{CO}_{2}$ e necropsiadas para a avaliação das seguintes lesões: aerossaculite, pericardite e perihepatite. 
Utilizou-se um índice de escore de lesão variando de 0 a 4 de acordo com as alterações macroscópicas encontradas. O quadro 7 detalha as características observadas.

Quadro 6 - Cepas de E. coli e concentrações utilizadas para a inoculação, por do via saco aéreo, de pintinhos SPF de um dia de idade

\begin{tabular}{|c|c|}
\hline Cepa & Título \\
\hline EC 269 S & $1 \times 10^{6}$ \\
\hline EC 269 M & $9 \times 10^{5}$ \\
\hline EC 341 S & $2 \times 10^{6}$ \\
\hline EC 341 M & $1,2 \times 10^{7}$ \\
\hline EC 713 S & $4 \times 10^{6}$ \\
\hline EC 713 M & $1 \times 10^{6}$ \\
\hline EC 775 S & $2 \times 10^{5}$ \\
\hline EC 775 M & $6 \times 10^{6}$ \\
\hline EC 1299 S & $3 \times 10^{6}$ \\
\hline EC 1299 M & $3 \times 10^{6}$ \\
\hline EC 1696 S & $5 \times 10^{6}$ \\
\hline EC 1696 M $1708 \mathrm{~S}$ & $3 \times 10^{6}$ \\
\hline EC 1708 M & $3 \times 10^{6}$ \\
\hline EC $1869 \mathrm{~S}$ & $4 \times 10^{6}$ \\
\hline EC 1869 M & $2 \times 10^{6}$ \\
\hline EC $1889 \mathrm{~S}$ & $2 \times 10^{5}$ \\
\hline EC $1889 \mathrm{M}$ & $1 \times 10^{6}$ \\
\hline
\end{tabular}

Quadro 7 - Escore de lesão para sacos aéreos, serosa hepática e pericárdio

\begin{tabular}{|c|l|c|}
\hline Local & \multicolumn{1}{|c|}{ Descrição } & Escore \\
\hline \multirow{5}{*}{ Sacos aéreos } & Normal & 0 \\
& Leve opacidade dos sacos aéreos. & 1 \\
& Opacidade localizada dos sacos aéreos e com presença de & 2 \\
& exsudato. & 3 \\
& Opacidade extensa e presença de placas de fibrina & 4 \\
\hline \multirow{5}{*}{ Fígado } & Normal & 0 \\
& Presença de fibrina em pequena quantidade & 1 \\
& Presença de placas de fibrina na superfície hepática & 2 \\
& Presença de fibrina extensa e que forma aderência no & 3 \\
& tecido hepático & 4 \\
\hline \multirow{5}{*}{ Coração } & Placas extensas e espessas de fibrina em todo o fígado & 0 \\
& Normal & 1 \\
& Quantidade excessiva de fluído claro dentro do saco & 2 \\
& pericárdico & 3 \\
& Opacidade no pericárdio ou presença de fluido turvo dentro & 4 \\
\hline & do saco pericárdico & \\
& Placas extensas de fibrina que revestem todo pericárdio & \\
\hline
\end{tabular}




\section{ANÁLISE ESTATÍSTICA}

\subsection{ANÁLISE ESTATÍSTICA DE AFLP}

Para a análise estatística dos fragmentos gerados foi utilizado o programa Bionumerics (AppliedMaths, Sint-Martens-Latem, Bélgica). A similaridade das amostras foi estimada por meio do coeficiente de Dice. Com a matriz de similaridade gerada foi possível se determinar os grupos pelo método de "Unweighthed PairGroup Method Using Arithmetic Average" (UPGMA).

\subsection{ANÁLISE ESTATÍSTICA DE PATOGENICIDADE E ESCORE DE LESÃO}

A mortalidade e a proteção contra as lesões (aerossaculite, pericardite e perihepatite) induzidas por $E$. coli foram comparadas utilizando-se o teste de Fischer. Os resultados foram considerados significantes quando $p<0,05$. 


\section{RESULTADOS}

\subsection{SUSCETIBILIDADE A ANTIMICROBIANOS}

Não ocorreram diferenças nos resultados obtidos nos dois testes quando utilizados com o mesmo antibiótico, com exceção da cepa EC 341 selvagem ou com mutação, que foi classificada como resistente no teste de concentração inibitória mínima (MIC) e parcialmente sensível na técnica de difusão em disco (TDD) frente à eritromicina.

\subsubsection{Concentração inibitória mínima (MIC)}

A suscetibilidade aos antimicrobianos por meio do método da concentração inibitória mínima (MIC) indicaram diferenças no perfil de suscetibilidade aos antibióticos nas nove amostras testadas.

Todas as cepas testadas selvagens ou tratadas com a substância mutagênica foram resistentes à lincomicina, oxaciclina, penicilina, tiamulina e tilmicosin e sensíveis a colistina e enrofloxacina.

A cepa EC 341 selvagem (S) ou tratada com a substância mutagênica (M) foi parcialmente resistente a eritromicina.

Ocorreram resistências nas amostras analisadas de 33,33\% a amoxacilina, de $11,11 \%$ a doxaciclina, de $55,55 \%$ a espectiomicina, de $66,66 \%$ a estreptomicina, de $77,77 \%$ a lincomicina-espectiomicina, de 33,33\% a neomicina, de 22,22\% a rifampicina, de 22,22\% a tetraciclina e de 33,33\% trimetropin-sulfa.

A amostra EC 1669 S tornou-se espontaneamente resistente a neomicina após a exposição a concentrações crescentes de ácido nalidíxico.

A tabela 1 apresenta estes resultados. 


\subsubsection{Técnica de difusão em disco (TDD)}

Todas as cepas testadas selvagens ou tratadas com a substância mutagênica foram resistentes à eritromicina e lincomicina e sensíveis ao cloranfenicol, ciprofloxacina, enrofloxacina, florfenicol e gentamicina. Ocorreram resistências nas amostras analisadas de $22,22 \%, 11,11 \%$ e $66,66 \%$, respectivamente, a ampicilina, a doxaciclina e a estreptomicina.

A amostra EC 1669 M tornou-se resistente ao ácido nalidíxico após a exposição a concentrações crescentes a este antibiótico e espontaneamente resistente a neomicina. A tabela 1 apresenta estes resultados.

\subsection{INDUÇÃO DE RESISTÊNCIA A ANTIMICROBIANOS}

Ocorreram alterações de sensibilidade nas cepas após a exposição a concentrações crescentes de rifampicina, eritromicina ou ácido nalidíxico. As cepas EC 269 S, EC 341 S, EC 713 S, EC 775 S, EC 1299 S e EC 1869 S, tornaram-se resistentes a rifampicina após a exposição a este antibiótico. As cepas EC $1708 \mathrm{~S}$ e EC 1889 S tornaram-se resistentes a estreptomicina e a cepa EC 1669 S tornou-se resistente após a exposição ao ácido nalidíxico. A tabela 1 apresenta estes resultados. 
Tabela 1 - Resultados dos testes de suscetibilidade a antimicrobianos ( $\mathrm{mg} / \mathrm{L}$ ), no teste de difusão em disco (TDD) em mm e no teste de concentração inibitória mínima em $\mu \mathrm{g} / \mathrm{mL}$

(Continua)

Cepas de Escherichia coli (cepas selvagens ou tratadas com concentrações crescentes de antibióticos)

\begin{tabular}{|c|c|c|c|c|c|c|c|}
\hline Antibióticos & Método ${ }^{1}$ & EC $269 \mathrm{~S}$ & EC $269 \mathrm{R}$ & EC $341 \mathrm{~S}$ & EC $341 \mathrm{R}$ & EC $713 \mathrm{~S}$ & EC $713 \mathrm{R}$ \\
\hline Ácido Nalidíxico & TDD & $26^{5}$ & $26^{5}$ & $32^{5}$ & $30^{5}$ & $28^{S}$ & $28^{S}$ \\
\hline Amoxaciclina & MIC & $\geq 2^{\mathrm{s}}$ & $\geq 2^{\mathrm{s}}$ & $\geq 16^{\mathrm{K}}$ & $\geq 16^{K}$ & $\geq 2^{\mathrm{s}}$ & $\geq 2^{\mathrm{s}}$ \\
\hline Ampicilina & TDD & $22^{\mathrm{s}}$ & $22^{\mathrm{s}}$ & $22^{s}$ & $22^{s}$ & $24^{\mathrm{s}}$ & $22^{\mathrm{s}}$ \\
\hline Cloranfenicol & TDD & $30^{\mathrm{S}}$ & $30^{\circ}$ & $32^{\mathrm{s}}$ & $30^{\mathrm{S}}$ & $30^{\mathrm{s}}$ & $28^{\mathrm{S}}$ \\
\hline Ciprofloxacina & TDD & $30^{\mathrm{s}}$ & $30^{\mathrm{s}}$ & $34^{\mathrm{s}}$ & $34^{\mathrm{S}}$ & $32^{\mathrm{s}}$ & $32^{\mathrm{s}}$ \\
\hline Colistina & MIC & $\leq 2^{\mathrm{S}}$ & $\leq 2^{\mathrm{S}}$ & $\leq 2^{\mathrm{S}}$ & $\leq 2^{\mathrm{S}}$ & $\leq 2^{\mathrm{S}}$ & $\leq 2^{\mathrm{S}}$ \\
\hline Doxaciclina & $\begin{array}{l}\text { MIC } \\
\text { TDD }\end{array}$ & $\begin{array}{l}\geq 2^{S} \\
24\end{array}$ & $\begin{array}{l}\geq 2^{S} \\
24\end{array}$ & $\begin{array}{l}\geq 2^{S} \\
28^{S}\end{array}$ & $\begin{array}{l}\leq 2 \mathrm{~S} \\
24^{S}\end{array}$ & $\begin{array}{l}\geq 2^{\mathrm{s}} \\
30^{\mathrm{S}}\end{array}$ & $\begin{array}{l}\geq 2^{s} \\
28^{S}\end{array}$ \\
\hline Enrofloxacina & $\mathrm{MIC}$ & $\leq 0,25^{\mathrm{s}}$ & $\leq 0,25^{\mathrm{s}}$ & $\leq 0,25^{\mathrm{s}}$ & $\leq 0,25^{\mathrm{s}}$ & $\leq 0,25^{\mathrm{s}}$ & $\leq 0,25^{\mathrm{s}}$ \\
\hline LIIU⿴囗十⺝ & TDD & $30^{\mathrm{S}}$ & $30^{\mathrm{S}}$ & $32^{\mathrm{S}}$ & $32^{\mathrm{S}}$ & $34^{\mathrm{S}}$ & $34^{\mathrm{S}}$ \\
\hline Eritromicina & MIC & $\geq 4^{\mathrm{K}}$ & $\geq 4^{K}$ & $\geq 4^{K}$ & $\geq 4^{\mathrm{H}}$ & $\geq 4^{\mathrm{K}}$ & $\geq 4^{\mathrm{K}}$ \\
\hline 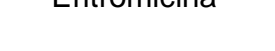 & TDD & $12^{\mathrm{R}}$ & $12^{\mathrm{R}}$ & $18^{\mathrm{PS}}$ & $16^{\mathrm{PS}}$ & $12^{\mathrm{R}}$ & $12^{\mathrm{R}}$ \\
\hline Espectiomicina & MIC & $<32^{\mathrm{S}}$ & $<32^{\mathrm{S}}$ & $<32^{\mathrm{s}}$ & $<32^{\mathrm{s}}$ & $\geq 64^{\mathrm{K}}$ & $\geq 64^{\mathrm{K}}$ \\
\hline Estreptomicina & MIC & $\geq 200^{\mathrm{K}}$ & $\geq 200^{\mathrm{K}}$ & $\geq 200^{K}$ & $\geq 200^{\mathrm{K}}$ & $\leq 200^{\mathrm{K}}$ & $\leq 200^{\mathrm{K}}$ \\
\hline & TDD & $8^{R}$ & $8^{R}$ & $10^{R}$ & $8^{R}$ & $10^{\mathrm{R}}$ & $10^{\mathrm{R}}$ \\
\hline Florfenicol & TDD & $26^{\mathrm{S}}$ & $26^{\mathrm{S}}$ & $32^{\mathrm{s}}$ & $32^{\mathrm{s}}$ & $30^{\mathrm{s}}$ & $28^{\mathrm{S}}$ \\
\hline Gentamicina & TDD & $16^{\mathrm{S}}$ & $16^{\mathrm{S}}$ & $20^{\mathrm{S}}$ & $20^{\mathrm{S}}$ & $22^{S}$ & $20^{\mathrm{S}}$ \\
\hline Lincomicina & MIC & $0^{\mathrm{R}}$ & $\begin{array}{l}\geq 4^{\mathrm{H}} \\
0^{\mathrm{R}}\end{array}$ & $\begin{array}{l}\geq 4^{\mathrm{K}} \\
0^{\mathrm{R}}\end{array}$ & $0^{\mathrm{R}}$ & $\geq 4^{\mathrm{H}}$ & $0^{\mathrm{R}}$ \\
\hline $\begin{array}{l}\text { Lincomicina- } \\
\text { espectiomicina }\end{array}$ & MIC & $\geq 8 / 32^{K}$ & $\geq 8 / 32^{\mathrm{K}}$ & $\geq 8 / 32^{\mathrm{K}}$ & $\geq 8 / 32^{\mathrm{K}}$ & $\geq 8 / 32^{\mathrm{K}}$ & $\geq 8 / 32^{\mathrm{K}}$ \\
\hline Neomicina & MIC & $10^{\mathrm{R}}$ & $10^{R}$ & $<8^{\mathrm{S}}$ & $<8^{S}$ & $\leq 8^{\mathrm{S}}$ & $\leq 8^{\mathrm{S}}$ \\
\hline Oxaciclina & MIC & $\geq 2^{\mathrm{K}}$ & $\geq 2^{\mathrm{K}}$ & $\geq 2^{\mathrm{K}}$ & $\geq 2^{\mathrm{K}}$ & $\geq 2^{\mathrm{K}}$ & $\leq 2^{K}$ \\
\hline Penicilina & MIC & $\geq 2^{\mathrm{K}}$ & $\geq 2^{\mathrm{H}}$ & $\geq 2^{\mathrm{K}}$ & $\geq 2^{\mathrm{K}}$ & $\geq 2^{\mathrm{K}}$ & $\geq 2^{\mathrm{H}}$ \\
\hline Rifampicina & MIC & $<50^{\mathrm{s}}$ & $\geq 50^{\mathrm{K}}$ & $<50^{\mathrm{s}}$ & $\geq 50^{\mathrm{K}}$ & $<50^{5}$ & $<50^{5}$ \\
\hline Tetraciclina & MIC & $\leq 2^{S}$ & $\leq 2^{\mathrm{s}}$ & $\leq 2^{\mathrm{S}}$ & $\leq 2^{\mathrm{s}}$ & $\leq 2^{\mathrm{S}}$ & $\leq 2^{\mathrm{s}}$ \\
\hline & TDD & $30^{\mathrm{s}}$ & $30^{s}$ & $30^{s}$ & $28^{\mathrm{S}}$ & $30^{s}$ & $30^{s}$ \\
\hline Tiamulin & MIC & $\geq 16^{\mathrm{K}}$ & $\geq 16^{\mathrm{K}}$ & $\geq 16^{\mathrm{K}}$ & $\geq 16^{\mathrm{K}}$ & $\geq 16^{\mathrm{K}}$ & $\geq 16^{\mathrm{K}}$ \\
\hline Tilmicosin & MIC & $\geq 16^{\mathrm{K}}$ & $\geq 16^{\mathrm{K}}$ & $\geq 16^{\mathrm{K}}$ & $\geq 16^{\mathrm{K}}$ & $\geq 16^{\mathrm{K}}$ & $\geq 16^{\mathrm{K}}$ \\
\hline Trimetropina-sulfa & MIC & $<0,5 / 9,5^{\mathrm{s}}$ & $<0,5 / 9,5^{\mathrm{s}}$ & $\geq 2 / 38^{\mathrm{K}}$ & $\geq 2 / 38^{K}$ & $\geq 2 / 38^{\mathrm{K}}$ & $\geq 2 / 38^{K}$ \\
\hline
\end{tabular}


(Continuação)

\begin{tabular}{|c|c|c|c|c|c|c|c|}
\hline \multicolumn{8}{|c|}{ Cepas de Escherichia coli (cepas selvagens ou tratadas com concentrações crescentes de antibióticos) } \\
\hline Antibióticos & Método ${ }^{1}$ & EC $775 \mathrm{~S}$ & EC $775 \mathrm{R}$ & EC $1299 \mathrm{~S}$ & EC $1299 \mathrm{R}$ & EC $1696 \mathrm{~S}$ & EC $1696 \mathrm{R}$ \\
\hline Ácido Nalidíxico & TDD & $24^{5}$ & $24^{5}$ & $20^{5}$ & $20^{5}$ & $28^{5}$ & $0^{\mathrm{K}}$ \\
\hline Amoxaciclina & MIC & $\geq 2^{5}$ & $\geq 2^{s}$ & $\geq 2^{S}$ & $\geq 2^{S}$ & $\geq 16^{\mathrm{K}}$ & $\geq 16^{K}$ \\
\hline Ampicilina & TDD & $20^{\mathrm{S}}$ & $20^{\mathrm{S}}$ & $18^{\mathrm{S}}$ & $18^{\mathrm{S}}$ & $20^{5}$ & $18^{\mathrm{S}}$ \\
\hline Cloranfenicol & TDD & $26^{\mathrm{s}}$ & $26^{\mathrm{s}}$ & $22^{s}$ & $22^{s}$ & $24^{s}$ & $24^{\mathrm{s}}$ \\
\hline Ciprofloxacina & TDD & $24^{\mathrm{S}}$ & $24^{\mathrm{S}}$ & $26^{\mathrm{s}}$ & $26^{\mathrm{s}}$ & $30^{\mathrm{S}}$ & $30^{\mathrm{S}}$ \\
\hline Colistina & MIC & $\leq 2^{\mathrm{s}}$ & $\leq 2^{S}$ & $\leq 2^{\mathrm{S}}$ & $\leq 2^{S}$ & $\leq 2^{\mathrm{s}}$ & $\leq 2^{\mathrm{s}}$ \\
\hline Doxaciclina & $\begin{array}{l}\text { MIC } \\
\text { TDD }\end{array}$ & $\begin{array}{l}<2^{S} \\
26^{s}\end{array}$ & $\begin{array}{l}<2^{s} \\
26^{s}\end{array}$ & $\begin{array}{l}<2^{s} \\
20^{s}\end{array}$ & $\begin{array}{l}<2^{s} \\
20^{s}\end{array}$ & $\begin{array}{l}<2^{s} \\
22^{S}\end{array}$ & $\begin{array}{l}<2^{s} \\
24^{s}\end{array}$ \\
\hline Enrofloxacina & MIC & $<0,25^{\mathrm{s}}$ & $<0,25^{\mathrm{s}}$ & $<0,25^{\mathrm{s}}$ & $<0,25^{\mathrm{s}}$ & $<0,25^{\mathrm{s}}$ & $<0,25^{\mathrm{s}}$ \\
\hline 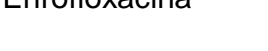 & TDD & $28^{\mathrm{S}}$ & $28^{\mathrm{S}}$ & $30^{\mathrm{S}}$ & $30^{\mathrm{S}}$ & $32^{\mathrm{S}}$ & $30^{\mathrm{S}}$ \\
\hline Eritromicina & MIC & $\geq 4^{\mathrm{K}}$ & $\geq 4^{\mathrm{H}}$ & $\geq 4^{\mathrm{K}}$ & $\geq 4^{\mathrm{K}}$ & $\geq 4^{\mathrm{H}}$ & $\geq 4^{\mathrm{h}}$ \\
\hline & TDD & $6^{R}$ & $6^{R}$ & $6^{R}$ & $6^{R}$ & $10^{R}$ & $10^{\mathrm{R}}$ \\
\hline Espectiomicina & MIC & $<32^{\mathrm{s}}$ & $<32^{\mathrm{s}}$ & $<32^{s}$ & $<32^{\mathrm{S}}$ & $\geq 64^{\mathrm{K}}$ & $\geq 64^{\mathrm{K}}$ \\
\hline Estreptomicina & MIC & $\geq 200^{R}$ & $\geq 200^{R}$ & $\geq 200^{R}$ & $\geq 200^{R}$ & $\geq 200^{R}$ & $\geq 200^{R}$ \\
\hline & TDD & $8^{s}$ & $20^{R}$ & $18^{\mathrm{R}}$ & $18^{\mathrm{R}}$ & $18^{\mathrm{R}}$ & $18^{\mathrm{R}}$ \\
\hline Florfenicol & TDD & $24^{s}$ & $24^{s}$ & $22^{s}$ & $22^{s}$ & $22^{s}$ & $22^{\mathrm{s}}$ \\
\hline Gentamicina & TDD & $16^{\mathrm{s}}$ & $16^{\mathrm{s}}$ & $20^{\mathrm{s}}$ & $20^{\mathrm{s}}$ & $24^{\mathrm{s}}$ & $24^{\mathrm{s}}$ \\
\hline Lincomicina & MIC & $\geq 4^{\mathrm{K}}$ & $\geq 4^{\mathrm{H}}$ & $\geq 4^{\mathrm{K}}$ & $\geq 4^{\mathrm{K}}$ & $\geq 4^{\mathrm{H}}$ & $\geq 4^{\mathrm{H}}$ \\
\hline Lincomicina- & MIC & $\leq 8 / 32^{\mathrm{S}}$ & $\leq 8 / 32^{\mathrm{S}}$ & $\geq 8 / 32^{R}$ & $\geq 8 / 32^{R}$ & $\geq 8 / 32^{R}$ & $\geq 8 / 32^{\mathrm{R}}$ \\
\hline Neomicina & MIC & $\geq 16^{\mathrm{K}}$ & $\geq 16^{\mathrm{K}}$ & $\geq 16^{\mathrm{K}}$ & $\geq 16^{\mathrm{K}}$ & $<8^{\mathrm{S}}$ & $\geq 16^{\mathrm{K}}$ \\
\hline Oxaciclina & MIC & $\geq 2^{\mathrm{K}}$ & $\geq 2^{\mathrm{K}}$ & $\geq 2^{\mathrm{K}}$ & $\geq 2^{\mathrm{K}}$ & $\geq 2^{\mathrm{K}}$ & $\geq 2^{\mathrm{K}}$ \\
\hline Penicilina & MIC & $\geq 2^{K}$ & $\geq 2^{\mathrm{K}}$ & $\geq 2^{K}$ & $\geq 2^{K}$ & $\geq 2^{\mathrm{K}}$ & $\geq 2^{\mathrm{K}}$ \\
\hline Rifampicina & MIC & $<50^{\circ}$ & $\geq 50^{K}$ & $<50^{5}$ & $\geq 50^{K}$ & $\geq 50^{\mathrm{K}}$ & $\geq 50^{K}$ \\
\hline Tetraciclina & MIC & $\leq 2^{\mathrm{s}}$ & $\leq 2^{\mathrm{S}}$ & $\leq 2^{\mathrm{S}}$ & $\leq 2^{\mathrm{S}}$ & $\leq 2^{\mathrm{S}}$ & $\leq 2^{S}$ \\
\hline & TDD & $28^{s}$ & $28^{s}$ & $26^{s}$ & $26^{s}$ & $26^{s}$ & $26^{s}$ \\
\hline Tiamulin & MIC & $\geq 16^{\mathrm{K}}$ & $\geq 16^{\mathrm{K}}$ & $\geq 16^{K}$ & $\geq 16^{\mathrm{K}}$ & $\geq 16^{\mathrm{K}}$ & $\geq 16^{\mathrm{K}}$ \\
\hline Tilmicosin & MIC & $\geq 16^{\mathrm{K}}$ & $\geq 16^{\mathrm{K}}$ & $\geq 16^{\mathrm{K}}$ & $\geq 16^{\mathrm{K}}$ & $\geq 16^{\mathrm{K}}$ & $\geq 16^{\mathrm{K}}$ \\
\hline Trimetropina-sulfa & MIC & $<0,5 / 9,5^{\mathrm{s}}$ & $<0,5 / 9,5^{\mathrm{s}}$ & $<0,5 / 9,5^{\mathrm{s}}$ & $<0,5 / 9,5^{\varsigma}$ & $<0,5 / 9,5^{\mathrm{s}}$ & $<0,5 / 9,5^{\varsigma}$ \\
\hline
\end{tabular}


(Conclusão)

\begin{tabular}{|c|c|c|c|c|c|c|c|}
\hline \multicolumn{8}{|c|}{ Cepas de Escherichia coli (cepas selvagens ou tratadas com concentrações crescentes de antibióticos) } \\
\hline Antibióticos & Método ${ }^{1}$ & EC $1708 \mathrm{~S}$ & EC $1708 \mathrm{R}$ & EC1869 S & EC $1869 \mathrm{R}$ & EC $1889 \mathrm{~S}$ & EC $1889 R$ \\
\hline Ácido Nalidíxico & TDD & $28^{S}$ & $28^{S}$ & $20^{5}$ & $20^{5}$ & $30^{5}$ & $30^{S}$ \\
\hline Amoxaciclina & MIC & $\leq 2^{S}$ & $\leq 2^{\mathrm{S}}$ & $<2^{S}$ & $<2^{\mathrm{S}}$ & $\geq 16^{K}$ & $\geq 16^{\mathrm{K}}$ \\
\hline Ampicilina & TDD & $28^{S}$ & $30^{s}$ & $8^{K}$ & $8^{K}$ & $8^{K}$ & $8^{K}$ \\
\hline Cloranfenicol & TDD & $28^{S}$ & $28^{\mathrm{S}}$ & $20^{5}$ & $20^{\mathrm{s}}$ & $20^{S}$ & $20^{5}$ \\
\hline Ciprofloxacina & TDD & $30^{\mathrm{s}}$ & $30^{\mathrm{s}}$ & $24^{\mathrm{S}}$ & $26^{\mathrm{S}}$ & $32^{s}$ & $34^{\mathrm{s}}$ \\
\hline Colistina & MIC & $\leq 2^{\mathrm{S}}$ & $\leq 2^{\mathrm{s}}$ & $\leq 2^{S}$ & $\leq 2^{\mathrm{s}}$ & $\leq 2^{\mathrm{s}}$ & $\leq 2^{S}$ \\
\hline Doxaciclina & MIC & $\leq 4^{\mathrm{PS}}$ & $\leq 4^{\mathrm{PS}}$ & $<2^{S}$ & $<2^{s}$ & $\geq 8^{\mathrm{R}}$ & $\geq 8^{\mathrm{R}}$ \\
\hline & TDD & $12^{P S}$ & $12^{\mathrm{PS}}$ & $20^{\mathrm{s}}$ & $20^{\mathrm{s}}$ & $12^{\mathrm{PS}}$ & $12^{\mathrm{PS}}$ \\
\hline Enrofloxacina & MIC & $\leq 0,25^{\mathrm{S}}$ & $\leq 0,25^{\mathrm{S}}$ & $<0,25^{\mathrm{s}}$ & $<0,25^{\mathrm{s}}$ & $<0,25^{\mathrm{s}}$ & $<0,25^{\mathrm{s}}$ \\
\hline & TDD & $32^{\mathrm{S}}$ & $32^{\mathrm{s}}$ & $32^{\mathrm{S}}$ & $32^{\mathrm{S}}$ & $34^{\mathrm{s}}$ & $34^{\mathrm{s}}$ \\
\hline Eritromicina & MIC & $\geq 4^{\mathrm{K}}$ & $\geq 4^{\mathrm{K}}$ & $\geq 4^{\mathrm{K}}$ & $\geq 4^{\mathrm{K}}$ & $\geq 4^{\mathrm{K}}$ & $\geq 4^{\mathrm{K}}$ \\
\hline & TDD & $0^{R}$ & $0^{R}$ & $18^{\mathrm{PS}}$ & $18^{P S}$ & $8^{R}$ & $8^{R}$ \\
\hline Espectiomicina & MIC & $\geq 64^{\mathrm{K}}$ & $\geq 64^{\mathrm{K}}$ & $\geq 64^{\mathrm{K}}$ & $\geq 64^{\mathrm{K}}$ & $\geq 64^{\mathrm{K}}$ & $\geq 64^{\mathrm{K}}$ \\
\hline Estreptomicina & MIC & $<200^{5}$ & $\geq 200^{\mathrm{K}}$ & $<200^{5}$ & $<200^{\circ}$ & $<200^{5}$ & $\geq 200^{\mathrm{H}}$ \\
\hline Florfenicol & TDD & $30^{\mathrm{S}}$ & $30^{5}$ & $30^{\mathrm{S}}$ & $30^{5}$ & $28^{S}$ & $28^{\mathrm{S}}$ \\
\hline Gentamicina & TDD & $20^{\mathrm{S}}$ & $18^{\mathrm{S}}$ & $22^{\mathrm{S}}$ & $20^{\mathrm{s}}$ & $20^{\mathrm{s}}$ & $20^{\mathrm{s}}$ \\
\hline Lincomicina & MIC & $\geq 4^{\mathrm{K}}$ & $\geq 4^{\mathrm{K}}$ & $\geq 4^{\mathrm{H}}$ & $\geq 4^{\mathrm{K}}$ & $\geq 4^{\mathrm{H}}$ & $\geq 4^{\mathrm{H}}$ \\
\hline $\begin{array}{l}\text { Lincomicina- } \\
\text { esnectiomicina }\end{array}$ & MIC & $\geq 8 / 32^{\mathrm{K}}$ & $\geq 8 / 32^{\mathrm{K}}$ & $<0,5 / 9,5^{s}$ & $<0,5 / 9,5^{\mathrm{s}}$ & $\geq 8 / 32^{\mathrm{K}}$ & $\geq 8 / 32^{K}$ \\
\hline Neomicina & MIC & $<8^{\mathrm{S}}$ & $<8^{\mathrm{S}}$ & $<8^{S}$ & $<8^{\mathrm{S}}$ & $<8^{\mathrm{S}}$ & $<8^{\mathrm{S}}$ \\
\hline Oxaciclina & MIC & $\geq 2^{K}$ & $\geq 2^{K}$ & $\geq 2^{K}$ & $\geq 2^{\mathrm{K}}$ & $\geq 2^{\mathrm{K}}$ & $\geq 2^{K}$ \\
\hline Penicilina & MIC & $\geq 2^{K}$ & $\geq 2^{K}$ & $\geq 2^{K}$ & $\geq 2^{\mathrm{K}}$ & $\geq 2^{\mathrm{K}}$ & $\geq 2^{K}$ \\
\hline Rifampicina & MIC & $\geq 50^{K}$ & $\geq 50^{\mathrm{K}}$ & $\leq 50^{\mathrm{S}}$ & $\geq 50^{K}$ & $\geq 50^{\mathrm{K}}$ & $\geq 50^{K}$ \\
\hline Tetraciclina & MIC & $\geq 8^{\mathrm{K}}$ & $\geq 8^{\mathrm{K}}$ & $<2^{\mathrm{s}}$ & $<2^{\mathrm{s}}$ & $\geq 8^{\mathrm{K}}$ & $\geq 8^{\mathrm{K}}$ \\
\hline & TDD & $0^{R}$ & $0^{R}$ & $28^{S}$ & $28^{s}$ & $0^{R}$ & $0^{R}$ \\
\hline Tiamulin & MIC & $\geq 16^{\mathrm{K}}$ & $\geq 16^{\mathrm{K}}$ & $\geq 16^{\mathrm{K}}$ & $\geq 16^{\mathrm{K}}$ & $\geq 16^{\mathrm{K}}$ & $\geq 16^{\mathrm{K}}$ \\
\hline Tilmicosin & MIC & $\geq 16^{\mathrm{K}}$ & $\geq 16^{\mathrm{K}}$ & $\geq 16^{\mathrm{K}}$ & $\geq 16^{\mathrm{K}}$ & $\geq 16^{\mathrm{K}}$ & $\geq 16^{\mathrm{K}}$ \\
\hline Trimetropina-sulfa & $\mathrm{MIC}$ & $<0,5 / 9,5^{\mathrm{s}}$ & $<0,5 / 9,5^{\mathrm{s}}$ & $<0,5 / 9,5^{s}$ & $<0,5 / 9,5^{\mathrm{s}}$ & $\leq 2 / 38^{\mathrm{H}}$ & $\leq 2 / 38^{\mathrm{H}}$ \\
\hline
\end{tabular}

${ }^{1}$ TDM - teste de MIC; TDD - teste de difusão em disco; Números em negrito - mudança de sensibilidade $\mathrm{EC}=$ Escherichia coli; $\mathrm{R}$ = resistente, $\mathrm{PS}-$ Parcialmente sensível, $\mathrm{S}=$ sensível.

$\mathrm{S}=$ selvagem; $\mathrm{M}$ = tratada com substância mutagênica 


\subsection{ANÁLISE POR PCR}

Os resultados da amplificação dos genes de virulência por PCR, mostraram que todas as cepas foram negativas para papC, cnf e afa. Algumas cepas apresentaram alteração na detecção dos fragmentos gênicos analisados, uma vez que apresentaram reações negativas para alguns genes após a exposição à substância mutagênica.

A cepa EC 269 S apresentou reação positiva para iuc, iss, tsh, cvi/cva, irp2, sfal e vat, apresentando-se negativa para os genes cvi/cva e sfal após a exposição a substância mutagênica (EC 269 M). A cepa EC 1869 S apresentou-se positiva para iuc, tsh, irp2, sfal e astA, apresentando-se negativa para os genes tsh, sfal e ast $A$ após exposição a substância mutagênica (EC 1869 M). A cepa EC 1889 S apresentou-se positiva para iuc, tsh, cvi/cva, irp2 e astA, apresentando-se negativa para tsh e cvi/cva após a exposição a substância mutagênica (EC 1889 M).

A cepa EC 341 S apresentou-se positiva para iuc, iss, irp2 e sfa. A cepa 775 $\mathrm{S}$ apresentou-se positiva para iss, tsh, iuc, irp2 e vat. $\mathrm{Na}$ cepa EC 1299 S os genes iuc, iss, tsh irp2 e sfa foram detectados. Os genes para iuc, tsh, cvi/cva e irp2 foram encontrados na cepa EC 713 S. A cepa EC 1696 S apresentouse positiva para iuc, iss e irp2 e a cepa EC 1708 S apresentou-se positiva para iuc e irp2. Nestas cepas não ocorreu nenhuma mudança na detecção de genes após a exposição à substância mutagênica. A tabela 2 apresenta estes resultados. 
Tabela 2 - Resultados da amplificação dos genes de virulência por PCR, nas cepas selvagens ou tratadas com a substância mutagênica

\begin{tabular}{|c|c|c|c|c|c|c|c|c|c|c|c|}
\hline Amostra & pap C & iuc & iss & tsh & $\begin{array}{l}\text { cvi/ } \\
\text { cva }\end{array}$ & irp2 & cnf & afa & sfa I & astA & vat \\
\hline EC $269 \mathrm{~S}$ & - & + & + & + & + & + & - & - & + & - & + \\
\hline EC 269 M & - & + & + & + & - & + & - & - & - & - & + \\
\hline EC $341 \mathrm{~S}$ & - & + & + & - & - & + & - & - & + & - & - \\
\hline EC $341 \mathrm{M}$ & - & + & + & - & - & + & - & - & + & - & - \\
\hline EC $713 \mathrm{~S}$ & - & + & - & + & + & + & - & - & - & - & - \\
\hline EC $713 \mathrm{M}$ & - & + & - & + & + & + & - & - & - & - & - \\
\hline EC 775 S & - & + & + & + & - & + & - & - & - & - & + \\
\hline EC $775 \mathrm{M}$ & - & + & + & + & - & + & - & - & - & - & + \\
\hline EC $1299 \mathrm{~S}$ & - & + & + & + & - & + & - & - & + & - & - \\
\hline EC $1299 \mathrm{M}$ & - & + & + & + & - & + & - & - & + & - & - \\
\hline EC $1696 \mathrm{~S}$ & - & + & + & - & - & + & - & - & - & - & - \\
\hline EC $1696 \mathrm{M}$ & - & + & + & - & - & + & - & - & - & - & - \\
\hline EC $1708 \mathrm{~S}$ & - & + & - & - & - & + & - & - & - & - & - \\
\hline EC $1708 \mathrm{M}$ & - & + & - & - & - & + & - & - & - & - & - \\
\hline EC $1869 \mathrm{~S}$ & - & + & - & + & - & + & - & - & + & + & - \\
\hline EC $1869 \mathrm{M}$ & - & + & - & - & - & + & - & - & - & - & - \\
\hline EC $1889 \mathrm{~S}$ & - & + & - & + & + & + & - & - & - & + & - \\
\hline EC $1889 \mathrm{M}$ & - & + & - & - & - & + & - & - & - & + & - \\
\hline
\end{tabular}

\subsection{CARACTERIZAÇÃO GENOTÍPICA POR AFLP}

Com o objetivo de se caracterizar e discriminar as cepas selvagens ou tratadas com a substância mutagênica foi empregada a técnica de AFPL. A similaridade entre os padrões foi calculada através do coeficiente de Dice.

A análise das 18 amostras (selvagens ou tratadas com a substância mutagênica) revelou diferenças em algumas bandas. A figura 1 mostra estes resultados. 


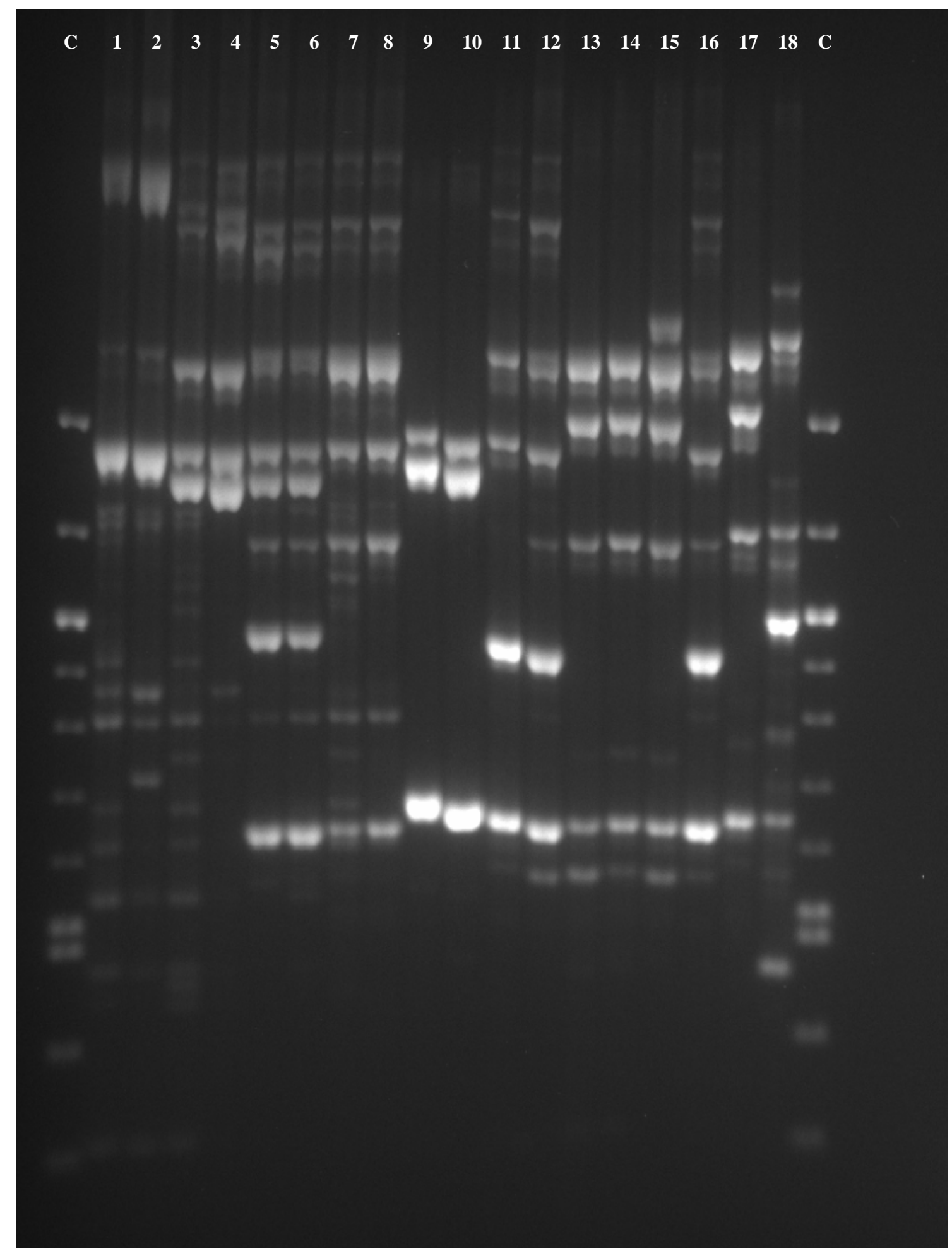

Figura 1 - Eletroforese em gel de agarose 1,5\%. Perfis obtidos através do AFLP em cepas de E.coli selvagens ou tratadas com a substância mutagênica. C - marcador de pares de base 100 pb DNA Ladder (LGC) 
A cepa EC 269 S comparada a EC 269 M revelou 76,9\% de similaridade pela ausência de algumas bandas. Estes resultados se encontram na figura 2.

Figura 2 - Comparação de bandas entre as cepas EC 269 S e EC 269 M
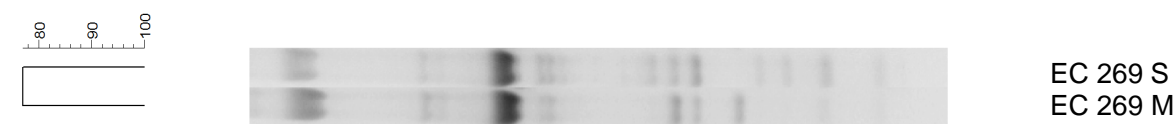

A cepa EC 341 S comparada a EC $341 \mathrm{M}$ revelou $76,9 \%$ de similaridade pela ausência de algumas bandas. A figura 3 apresenta estes resultados.

Figura 3 - Comparação de bandas entre as cepas EC 341 S e EC $341 \mathrm{M}$

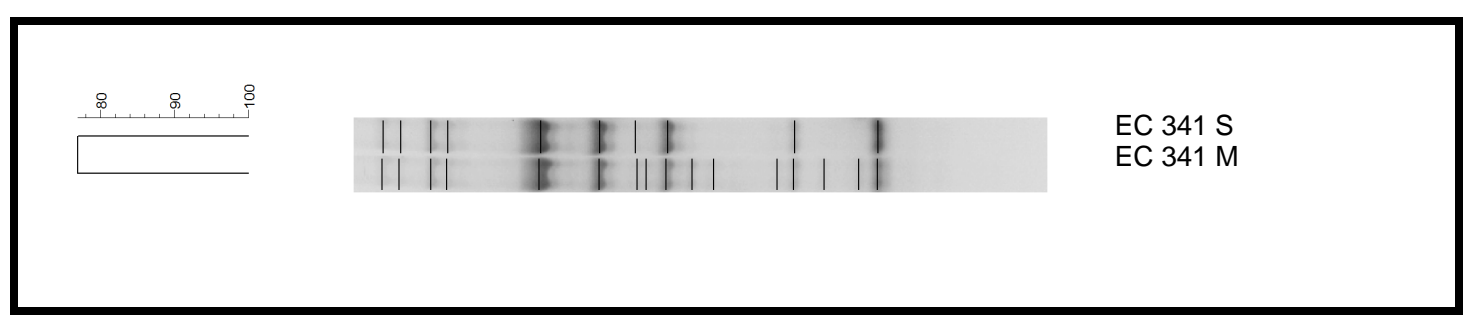

A cepa EC 713 S comparada a EC 713 M revelou 100,0 \% de similaridade. Estes resultados se encontram na figura 4.

Figura 4 - Comparação de bandas entre as cepas EC 713 S e EC 713 M

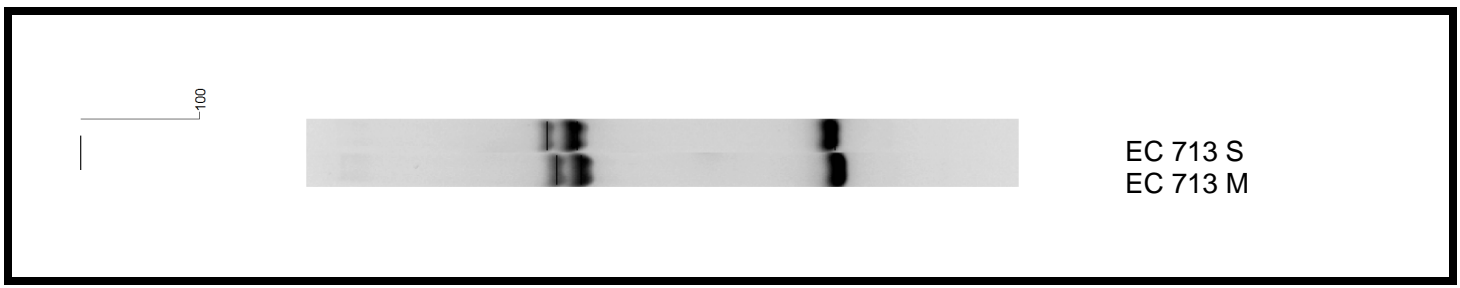


A cepa EC 775 S comparada a EC 775 M revelou 46,6\% de similaridade pela ausência de algumas bandas. A figura 5 apresenta estes resultados.

Figura 5 - Comparação de bandas entre as cepas EC 775 S e EC 775 M
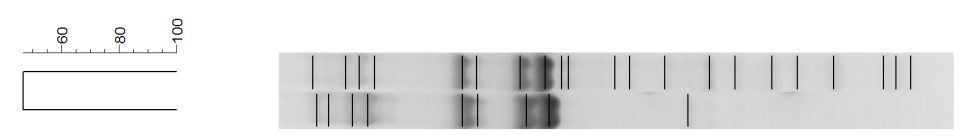

A cepa EC 1299 S comparada a EC 1299 M revelou 96,3\% de similaridade pela ausência de algumas bandas. Estes resultados se encontram na figura 6 .

Figura 6 - Comparação de bandas entre as cepas EC 1299 S e EC 1299 M

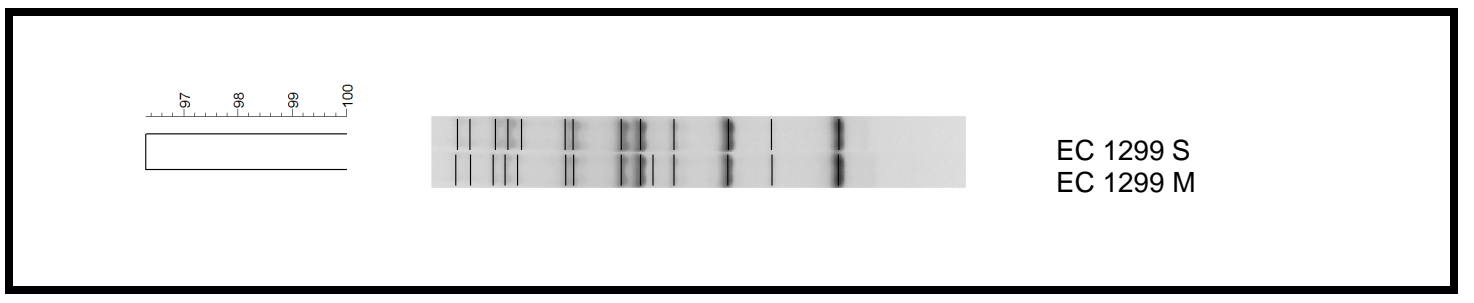

A cepa EC 1669 S comparada a EC 1669 M revelou 78,2 \% de similaridade pela ausência de algumas bandas. A figura 7 apresenta estes resultados.

Figura 7 - Comparação de bandas entre as cepas EC 1669 S e EC 1669 M
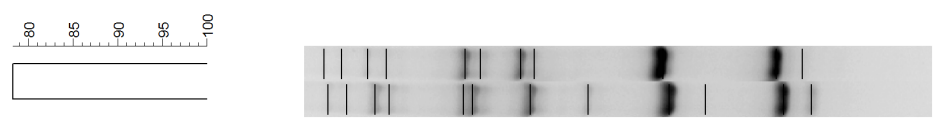
A cepa EC 1708 S comparada a EC 1708 M revelou $94 \%$ de similaridade pela ausência de algumas bandas. Estes resultados se encontram na figura 8.

Figura 8 - Comparação de bandas entre as cepas EC 1708 S e EC 1708 M

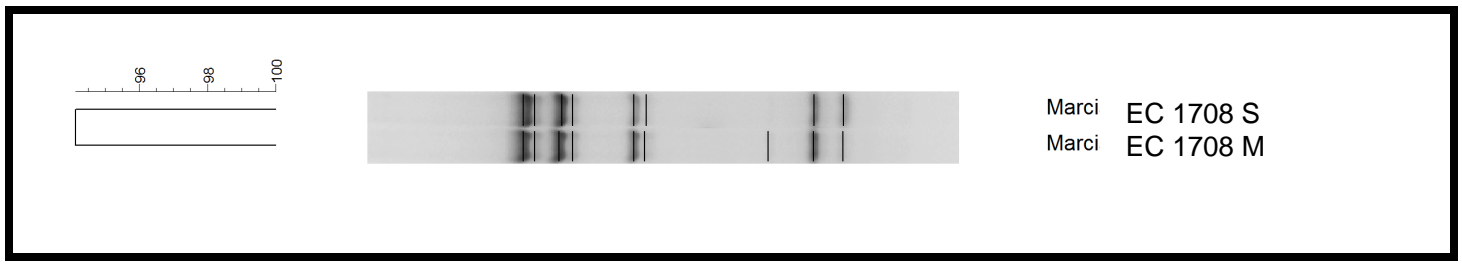

A cepa EC 1869 S comparada a EC 1869 M revelou $40 \%$ de similaridade pela ausência de algumas bandas. A figura 9 apresenta estes resultados.

Figura 9 - Comparação de bandas entre as cepas EC 1869 S e EC 1869 M

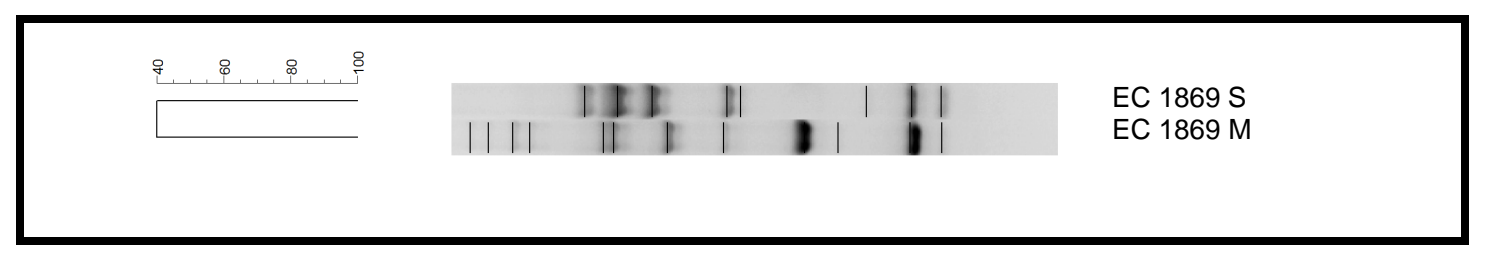

A cepa EC 1889 S comparada a EC 1889 M revelou $60,8 \%$ de similaridade pela ausência de algumas bandas. Estes resultados se encontram na figura 10.

Figura 10 - Comparação de bandas entre as cepas EC 1889 S e EC 1889 M

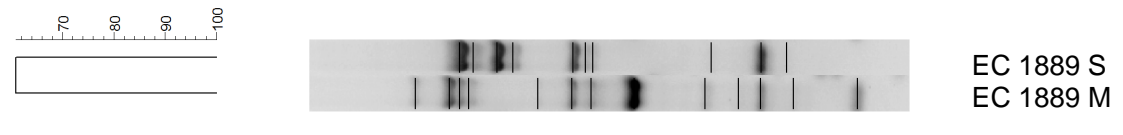




\subsection{AVALIAÇÃO DE CEPAS SELVAGENS OU TRATADAS COM A SUBSTÂNCIA MUTAGÊNICA EM PINTINHOS DE UM DIA DE IDADE}

O controle ambiental para E. coli demonstrou a ausência da bactéria na água, bebedouros, ração, balança, comedouros, papéis para forração, maravalha e equipamentos.

As cepas foram avaliadas em função da mortalidade, patogenicidade e escore de lesões apresentados pelas aves e os resultados obtidos organizados em tabelas e gráficos para uma melhor compreensão.

\subsubsection{Mortalidade}

Após a inoculação das bactérias selvagens ocorreram mortes nos grupos de pintinhos inoculados durante os 10 dias de observação. Alguns grupos inoculados com as cepas bacterianas apresentaram modificações na patogenicidade quando comparadas com as cepas selvagens.

No grupo T3 (inoculado com a cepa EC $341 \mathrm{~S}$ ), ocorreu a maior mortalidade, com 10 pintinhos mortos nas primeiras 24 horas, sendo classificada como uma cepa de alta patogenicidade. A cepa correspondente com mutação causou a morte de oito (08) pintinhos, sendo a sua patogenicidade classificada como intermediária.

A patogenicidade da cepa EC 269 S (grupo T1) e da EC 713 S (grupo T5) foram classificadas como intermediária. Após o tratamento com a substância mutagênica estas cepas passaram a apresentar baixa patogenicidade. As cepas com mutação EC 775 M (grupo T8) e EC 1869 M (grupo T16) foram classificadas como não patogênica, enquanto as cepas selvagens correspondentes apresentaram baixa patogenicidade.

Os dados estão expostos na tabela 3 e ilustrados na figura 11.

As diferenças entre mortalidade dos pintinhos dos diferentes grupos não foram significativas nas comparações entre as cepas selvagens e suas respectivas cepas com mutação ( $p \leq 0,05)$. 
Tabela 3 - Mortalidade de pintinhos SPF inoculados com cepas de E. coli selvagens ou com mutações, nos 10 dias de observação e a classificação de patogenicidade

\begin{tabular}{|c|c|c|c|c|c|c|c|c|c|c|c|c|c|c|}
\hline \multirow{2}{*}{ Grupo } & \multirow[b]{2}{*}{ Cepa } & \multirow{2}{*}{$\mathbf{n}$} & \multicolumn{10}{|c|}{ Dias } & \multirow{2}{*}{ Total } & \multirow{2}{*}{ Patogenicidade } \\
\hline & & & 01 & 02 & 03 & 04 & 05 & 06 & 07 & 08 & 09 & 10 & & \\
\hline T1 & EC $269 \mathrm{~S}$ & 10 & 3 & 1 & 1 & 0 & 0 & 0 & 0 & 0 & 0 & 0 & 5 & Intermediária \\
\hline T2 & EC $269 \mathrm{M}$ & 10 & 0 & 0 & 0 & 0 & 1 & 1 & 0 & 0 & 0 & 0 & 2 & Baixa \\
\hline T3 & EC $341 \mathrm{~S}$ & 10 & 10 & 0 & 0 & 0 & 0 & 0 & 0 & 0 & 0 & 0 & 10 & Alta \\
\hline $\mathrm{T4}$ & EC $341 \mathrm{M}$ & 10 & 5 & 0 & 1 & 0 & 0 & 1 & 0 & 1 & 0 & 0 & 8 & Intermediária \\
\hline T5 & EC $713 \mathrm{~S}$ & 10 & 7 & 0 & 1 & 0 & 0 & 0 & 0 & 0 & 0 & 0 & 8 & Intermediária \\
\hline T6 & EC $713 \mathrm{M}$ & 10 & 1 & 0 & 0 & 0 & 0 & 0 & 0 & 0 & 0 & 0 & 1 & Baixa \\
\hline $\mathrm{T7}$ & EC 775 S & 10 & 1 & 1 & 1 & 0 & 0 & 0 & 0 & 0 & 0 & 0 & 3 & Baixa \\
\hline T8 & EC $775 \mathrm{M}$ & 10 & 0 & 0 & 0 & 0 & 0 & 0 & 0 & 0 & 0 & 0 & 0 & Não patogênica \\
\hline T9 & EC $1299 \mathrm{~S}$ & 10 & 0 & 0 & 0 & 0 & 0 & 0 & 0 & 0 & 0 & 0 & 0 & Não patogênica \\
\hline T10 & EC $1299 \mathrm{M}$ & 10 & 0 & 0 & 0 & 0 & 0 & 0 & 0 & 0 & 0 & 0 & 0 & Não patogênica \\
\hline T11 & EC $1669 \mathrm{~S}$ & 10 & 0 & 0 & 0 & 0 & 0 & 0 & 0 & 0 & 0 & 0 & 0 & Não patogênica \\
\hline T12 & EC $1669 \mathrm{M}$ & 10 & 0 & 0 & 0 & 0 & 0 & 0 & 0 & 0 & 0 & 0 & 0 & Não patogênica \\
\hline T13 & EC $1708 \mathrm{~S}$ & 10 & 0 & 0 & 0 & 0 & 0 & 0 & 0 & 0 & 0 & 0 & 0 & Não patogênica \\
\hline T14 & EC $1708 \mathrm{M}$ & 10 & 0 & 0 & 0 & 0 & 0 & 0 & 0 & 0 & 0 & 0 & 0 & Não patogênica \\
\hline T15 & EC $1869 \mathrm{~S}$ & 10 & 0 & 0 & 0 & 0 & 1 & 0 & 0 & 0 & 0 & 0 & 1 & Baixa \\
\hline T16 & EC $1889 \mathrm{M}$ & 10 & 0 & 0 & 0 & 0 & 0 & 0 & 0 & 0 & 0 & 0 & 0 & Não patogênica \\
\hline T17 & EC $1889 \mathrm{~S}$ & 10 & 7 & 0 & 1 & 0 & 0 & 0 & 0 & 0 & 0 & 0 & 8 & Intermediária \\
\hline T18 & EC $1889 \mathrm{M}$ & 10 & 7 & 2 & 0 & 0 & 0 & 0 & 0 & 0 & 0 & 0 & 9 & Alta \\
\hline T19 & C1 & 10 & 0 & 0 & 0 & 0 & 0 & 0 & 0 & 0 & 0 & 0 & 0 & - \\
\hline T20 & C2 & 10 & 0 & 0 & 0 & 0 & 0 & 0 & 0 & 0 & 0 & 0 & 0 & - \\
\hline
\end{tabular}

Figura 11 - Mortalidade total de pintinhos SPF inoculados com as cepas de E. coli selvagens ou com mutações, nos 10 dias de observação

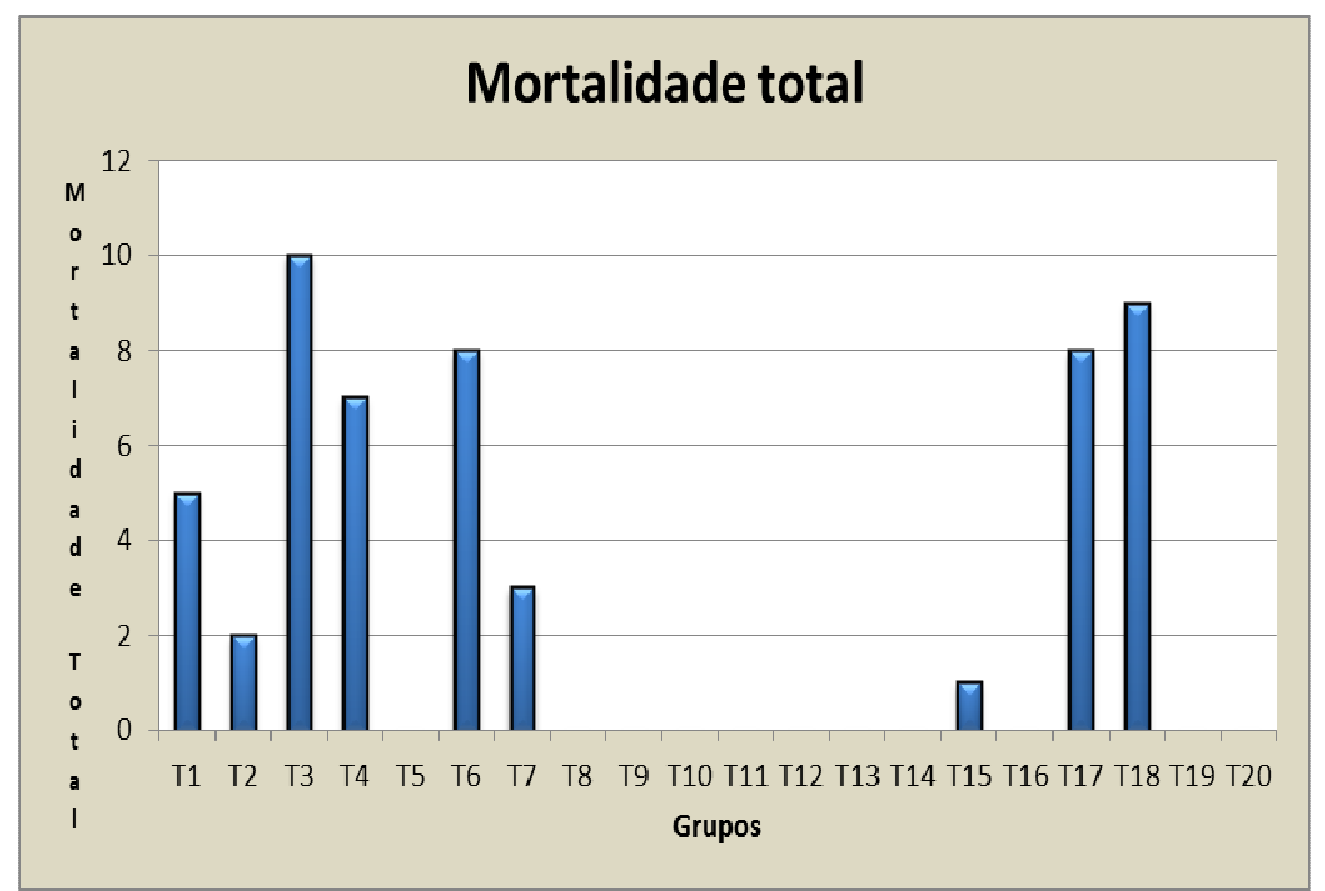




\subsubsection{Escore de lesões}

O escore de lesões causadas pelas $E$. coli selvagens ou com mutações foi avaliado após 10 dias da inoculação.

As aves apresentaram lesões principalmente em sacos aéreos torácicos direitos (local da inoculação). Em alguns grupos observaram-se lesões em sacos aéreos torácicos esquerdos e número muito reduzido de lesões em sacos aéreos abdominais. Pericardite foi observada em poucas aves. Nenhuma ave apresentou perihepatite.

Os dados estão expostos na tabela 4 e 5 e ilustrados na figura 12.

Tabela 4 - Número de pintinhos com lesão provocada por cepas selvagens de $E$. coli ou tratadas com a substância mutagênica, após 10 dias da inoculação

\begin{tabular}{cccccccc}
\hline Cepa & $\mathbf{n}$ & Cepa & $\begin{array}{c}\text { Aerossaculite } \\
\text { (Saco torácico } \\
\text { direito) }\end{array}$ & $\begin{array}{c}\text { Aerossaculite } \\
\text { (Saco torácico } \\
\text { esquerdo) }\end{array}$ & $\begin{array}{c}\text { Aerossaculite } \\
\text { (saco abdominal) }\end{array}$ & Pericardite & Perihepatite \\
\hline T1 & 5 & EC 269 S & 4 & 2 & 0 & 0 & 0 \\
T2 & 8 & EC 269 M & 5 & 1 & 0 & 0 & 0 \\
T3 & 0 & EC 341 S & 0 & 0 & 0 & 0 & 0 \\
T4 & 2 & EC 341 M & 3 & 3 & 1 & 0 & 0 \\
T5 & 2 & EC 713 S & 2 & 2 & 0 & 1 & 0 \\
T6 & 9 & EC 713 M & 3 & 0 & 0 & 0 & 0 \\
T7 & 7 & EC 775 S & 7 & 2 & 2 & 2 & 0 \\
T8 & 10 & EC 775 M & 9 & 0 & 1 & 0 & 0 \\
T9 & 10 & EC 1299 S & 10 & 7 & 0 & 0 & 0 \\
T10 & 10 & EC 1299 M & 3 & 0 & 0 & 0 & 0 \\
T11 & 10 & EC 1669 S & 6 & 4 & 0 & 0 & 0 \\
T12 & 10 & EC 1669 M & 6 & 2 & 0 & 0 & 0 \\
T13 & 10 & EC 1708 S & 9 & 5 & 0 & 0 & 0 \\
T14 & 10 & EC 1708 M & 4 & 1 & 0 & 0 & 0 \\
T15 & 9 & EC 1869 S & 9 & 2 & 0 & 0 & 0 \\
T16 & 10 & EC 1869 M & 4 & 0 & 0 & 2 & 0 \\
T17 & 2 & EC 1889 S & 2 & 2 & 0 & 0 \\
T18 & 1 & EC 1889 M & 1 & 1 & 0 & 0 & 0 \\
T19 & 10 & C1 & 0 & 0 & 0 & 0 & 0 \\
T20 & 10 & C2 & 0 & 0 & & 0 & 0 \\
\hline
\end{tabular}


Figura 12 - Número de aves com lesões, após10 dias da inoculação de cepas de $E$. coli selvagens ou com mutações

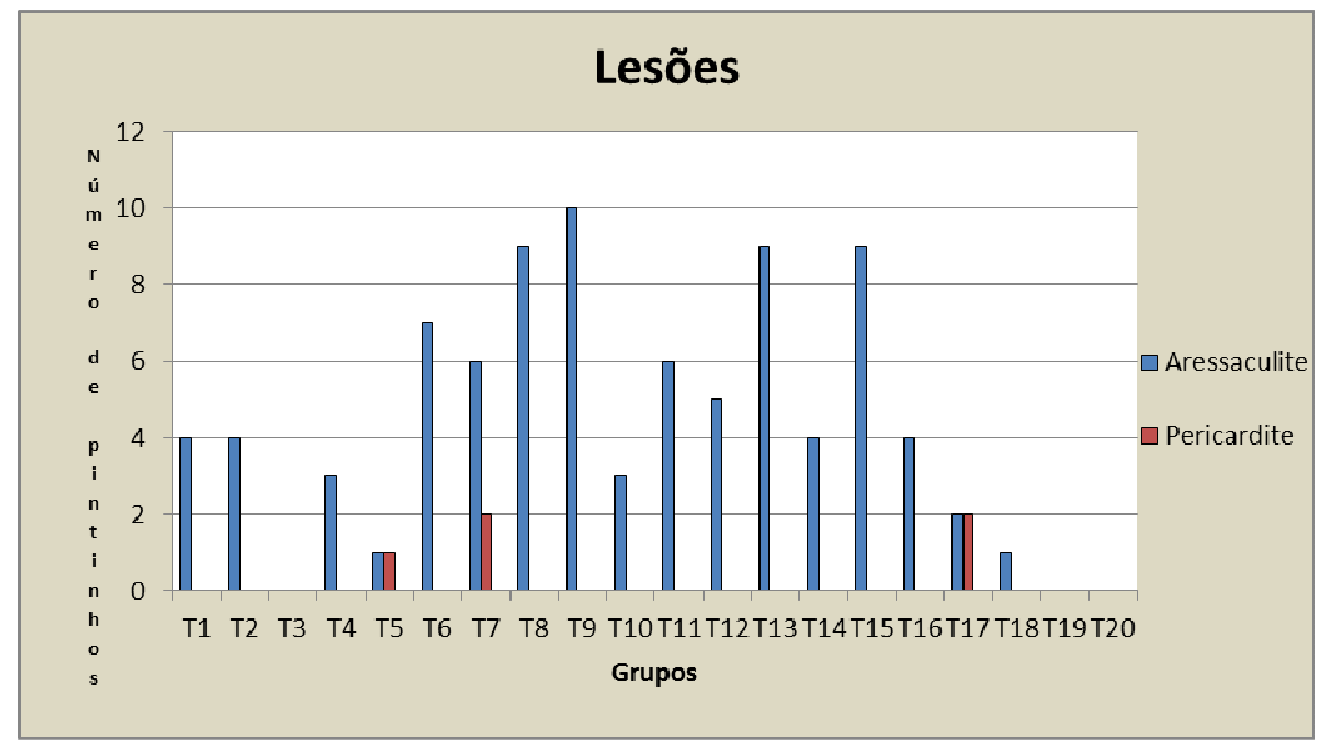

Tabela 5 - Escore de lesões em sacos aéreos de aves inoculadas com cepas de E. coli classificadas em um escore de 0 a 4

\begin{tabular}{|c|c|c|c|c|c|c|c|c|c|c|c|c|c|c|c|c|c|}
\hline \multirow{2}{*}{ Grupo } & \multirow[b]{2}{*}{ Cepa } & \multirow[b]{2}{*}{$\mathbf{n}$} & \multicolumn{5}{|c|}{ Saco aéreo torácico direito } & \multicolumn{5}{|c|}{ Saco aéreo torácico esquerdo } & \multicolumn{5}{|c|}{ Saco aéreo abdominal } \\
\hline & & & 0 & 1 & 2 & 3 & 4 & 0 & 1 & 2 & 3 & 4 & 0 & 1 & 2 & 3 & 4 \\
\hline T1 & EC $269 \mathrm{~S}$ & 5 & 1 & 2 & 1 & 1 & 0 & 3 & 2 & 0 & 0 & 0 & 5 & 0 & 0 & 0 & 0 \\
\hline T2 & EC $269 \mathrm{M}$ & 8 & 3 & 3 & 1 & 1 & 0 & 7 & 1 & 0 & 0 & 0 & 8 & 0 & 0 & 0 & 0 \\
\hline T3 & EC $341 \mathrm{~S}$ & 0 & 0 & 0 & 0 & 0 & 0 & 0 & 0 & 0 & 0 & 0 & 0 & 0 & 0 & 0 & 0 \\
\hline T4 & $\mathrm{EC} 341 \mathrm{M}$ & 2 & 0 & 1 & 1 & 0 & 0 & 1 & 1 & 0 & 0 & 0 & 1 & 1 & 0 & 0 & 0 \\
\hline T5 & EC $713 \mathrm{~S}$ & 2 & 0 & 0 & 1 & 0 & 1 & 1 & 1 & 0 & 0 & 0 & 0 & 0 & 0 & 0 & 0 \\
\hline T6 & EC $713 \mathrm{M}$ & 9 & 2 & 5 & 2 & 0 & 0 & 9 & 0 & 0 & 0 & 0 & 9 & 0 & 0 & 0 & 0 \\
\hline T7 & EC $775 \mathrm{~S}$ & 7 & 0 & 1 & 1 & 2 & 3 & 5 & 1 & 1 & 0 & 0 & 5 & 1 & 1 & 0 & 0 \\
\hline T8 & EC $775 \mathrm{M}$ & 10 & 1 & 6 & 3 & 0 & 0 & 10 & 0 & 0 & 0 & 0 & 9 & 1 & 0 & 0 & 0 \\
\hline T9 & EC $1299 \mathrm{~S}$ & 10 & 0 & 4 & 5 & 1 & 0 & 6 & 2 & 2 & 0 & 0 & 8 & 2 & 0 & 0 & 0 \\
\hline T10 & EC $1299 \mathrm{M}$ & 10 & 7 & 2 & 1 & 0 & 0 & 10 & 0 & 0 & 0 & 0 & 10 & 0 & 0 & 0 & 0 \\
\hline T11 & EC $1669 \mathrm{~S}$ & 10 & 4 & 4 & 2 & 0 & 0 & 6 & 4 & 0 & 0 & 0 & 10 & 0 & 0 & 0 & 0 \\
\hline T12 & EC $1669 \mathrm{M}$ & 10 & 4 & 4 & 1 & 1 & 0 & 8 & 2 & 0 & 0 & 0 & 10 & 0 & 0 & 0 & 0 \\
\hline T13 & EC $1708 \mathrm{~S}$ & 10 & 1 & 5 & 2 & 2 & 0 & 5 & 2 & 2 & 1 & 0 & 8 & 2 & 0 & 0 & 0 \\
\hline T14 & EC $1708 \mathrm{M}$ & 10 & 6 & 4 & 0 & 0 & 0 & 9 & 1 & 0 & 0 & 0 & 10 & 0 & 0 & 0 & 0 \\
\hline T15 & EC $1869 \mathrm{~S}$ & 9 & 0 & 7 & 2 & 0 & 0 & 7 & 2 & 0 & 0 & 0 & 10 & 0 & 0 & 0 & 0 \\
\hline T16 & EC $1869 \mathrm{M}$ & 10 & 6 & 4 & 0 & 0 & 0 & 10 & 0 & 0 & 0 & 0 & 10 & 0 & 0 & 0 & 0 \\
\hline T17 & EC $1889 \mathrm{~S}$ & 2 & 0 & 1 & 1 & 0 & 0 & 2 & 0 & 0 & 0 & 0 & 2 & 0 & 0 & 0 & 0 \\
\hline T18 & EC $1889 \mathrm{M}$ & 1 & 0 & 0 & 1 & 0 & 0 & 1 & 0 & 0 & 0 & 0 & 1 & 0 & 0 & 0 & 0 \\
\hline T19 & $\mathrm{C} 1$ & 10 & 10 & 0 & 0 & 0 & 0 & 10 & 0 & 0 & 0 & 0 & 10 & 0 & 0 & 0 & 0 \\
\hline T20 & $\mathrm{C} 2$ & 10 & 10 & 0 & 0 & 0 & 0 & 10 & 0 & 0 & 0 & 0 & 10 & 0 & 0 & 0 & 0 \\
\hline
\end{tabular}

Ocorreram diferenças significativas em relação ao escore de lesões na comparação entre os grupos T5 (EC 713 S) e T6 (EC 713 M), T9 (EC 1299 S) e T10 (EC 1299 M), T13 (EC 1708 S) e T14 (EC 1708 M) e T15 (EC 1869 S) e T16 (EC 1869 M) $(p \leq 0,05)$. Os dados estão expostos na tabela 6. 
Tabela 6 - Escore de lesões em coração inoculadas com cepas de E. coli classificadas em um escore de 0 a 4

\begin{tabular}{|c|c|c|c|c|c|c|c|}
\hline \multirow{2}{*}{ Grupo } & \multirow{2}{*}{ Cepa } & \multirow{2}{*}{$\mathbf{N}$} & \multicolumn{5}{|c|}{ Pericardite } \\
\hline & & & 0 & 1 & 2 & 3 & 4 \\
\hline T1 & EC $269 \mathrm{~S}$ & 5 & 5 & 0 & 0 & 0 & 0 \\
\hline T2 & EC $269 \mathrm{M}$ & 8 & 8 & 0 & 0 & 0 & 0 \\
\hline T3 & EC $341 \mathrm{~S}$ & 0 & 0 & 0 & 0 & 0 & 0 \\
\hline T4 & EC $341 \mathrm{M}$ & 2 & 1 & 1 & 0 & 0 & 0 \\
\hline T5 & EC $713 \mathrm{~S}$ & 2 & 2 & 0 & 0 & 0 & 0 \\
\hline T6 & EC $713 \mathrm{M}$ & 9 & 7 & 2 & 0 & 0 & 0 \\
\hline T7 & EC $775 \mathrm{~S}$ & 7 & 7 & 0 & 0 & 0 & 0 \\
\hline T8 & EC $775 \mathrm{M}$ & 10 & 10 & 0 & 0 & 0 & 0 \\
\hline T9 & EC $1299 \mathrm{~S}$ & 10 & 10 & 0 & 0 & 0 & 0 \\
\hline T10 & EC $1299 \mathrm{M}$ & 10 & 10 & 0 & 0 & 0 & 0 \\
\hline T11 & EC $1669 \mathrm{~S}$ & 10 & 10 & 0 & 0 & 0 & 0 \\
\hline T12 & EC $1669 \mathrm{M}$ & 10 & 10 & 0 & 0 & 0 & 0 \\
\hline T13 & EC $1708 \mathrm{~S}$ & 10 & 10 & 0 & 0 & 0 & 0 \\
\hline T14 & EC $1708 \mathrm{M}$ & 10 & 10 & 0 & 0 & 0 & 0 \\
\hline T15 & EC $1869 \mathrm{~S}$ & 9 & 9 & 0 & 0 & 0 & 0 \\
\hline T16 & EC $1869 \mathrm{M}$ & 10 & 8 & 0 & 1 & 0 & 1 \\
\hline T17 & EC $1889 \mathrm{~S}$ & 2 & 2 & 0 & 0 & 0 & 0 \\
\hline T18 & EC $1889 \mathrm{M}$ & 1 & 1 & 0 & 0 & 0 & 0 \\
\hline T19 & C1 & 10 & 10 & 0 & 0 & 0 & 0 \\
\hline T20 & $\mathrm{C} 2$ & 10 & 10 & 0 & 0 & 0 & 0 \\
\hline
\end{tabular}

Tabela 7 - Diferenças entre cepas selvagens ou com mutações em relação aos fatores de virulência, a similaridade em AFLP, a patogenicidade, a mortalidade e ao escore de lesões

\begin{tabular}{|c|c|c|c|c|c|c|}
\hline \multirow[b]{2}{*}{ Grupo } & \multirow[b]{2}{*}{ Cepa } & \multicolumn{5}{|c|}{ Diferenças } \\
\hline & & $\begin{array}{l}\text { Fatores de } \\
\text { virulência }\end{array}$ & $\begin{array}{c}\text { Similaridade } \\
\text { em AFLP }\end{array}$ & Patogenicidade & Mortalidade & $\begin{array}{c}\text { Escore de } \\
\text { lesões }\end{array}$ \\
\hline $\begin{array}{l}\text { T1 } \\
\text { T2 }\end{array}$ & $\begin{array}{l}\text { EC } 269 \mathrm{~S} \\
\text { EC } 269 \mathrm{M}\end{array}$ & cvi/cva e sfal & $76,9 \%$ & $\begin{array}{c}\text { Intermediária } \\
\text { Baixa }\end{array}$ & $\begin{array}{l}- \\
-\end{array}$ & - \\
\hline $\begin{array}{l}\text { T3 } \\
\text { T4 }\end{array}$ & $\begin{array}{l}\text { EC } 341 \mathrm{~S} \\
\text { EC } 341 \mathrm{M}\end{array}$ & - & $76,9 \%$ & $\begin{array}{c}\text { Alta } \\
\text { Intermediária }\end{array}$ & $\begin{array}{l}- \\
-\end{array}$ & - \\
\hline $\begin{array}{l}\text { T5 } \\
\text { T6 }\end{array}$ & $\begin{array}{l}\text { EC } 713 \mathrm{~S} \\
\text { EC } 713 \mathrm{M}\end{array}$ & - & $100,0 \%$ & $\begin{array}{c}\text { Intermediária } \\
\text { Baixa }\end{array}$ & $\begin{array}{l}- \\
-\end{array}$ & + \\
\hline $\begin{array}{l}\text { T7 } \\
\text { T8 }\end{array}$ & $\begin{array}{l}\text { EC } 775 \mathrm{~S} \\
\text { EC } 775 \mathrm{M}\end{array}$ & - & $46,6 \%$ & $\begin{array}{l}\text { Não patogênica } \\
\text { Não patogênica }\end{array}$ & $\begin{array}{l}- \\
-\end{array}$ & - \\
\hline $\begin{array}{l}\text { T9 } \\
\text { T10 }\end{array}$ & $\begin{array}{l}\text { EC } 1299 \mathrm{~S} \\
\text { EC } 1299 \mathrm{M}\end{array}$ & - & $96,3 \%$ & $\begin{array}{l}\text { Não patogênica } \\
\text { Não patogênica }\end{array}$ & - & + \\
\hline $\begin{array}{l}\text { T11 } \\
\text { T12 }\end{array}$ & $\begin{array}{l}\text { EC } 1669 \mathrm{~S} \\
\text { EC } 1669 \mathrm{M}\end{array}$ & - & $78,2 \%$ & $\begin{array}{l}\text { Não patogênica } \\
\text { Não patogênica }\end{array}$ & $\begin{array}{l}- \\
-\end{array}$ & - \\
\hline $\begin{array}{l}\text { T13 } \\
\text { T14 }\end{array}$ & $\begin{array}{l}\text { EC } 1708 \mathrm{~S} \\
\text { EC } 1708 \mathrm{M}\end{array}$ & - & $94 \%$ & $\begin{array}{l}\text { Não patogênica } \\
\text { Não patogênica }\end{array}$ & $\begin{array}{l}- \\
-\end{array}$ & + \\
\hline $\begin{array}{l}\text { T15 } \\
\text { T16 }\end{array}$ & $\begin{array}{l}\text { EC } 1869 \mathrm{~S} \\
\text { EC } 1869 \mathrm{M}\end{array}$ & tsh, sfal e astA & $40 \%$ & $\begin{array}{c}\text { Baixa } \\
\text { Não patogênica }\end{array}$ & $\begin{array}{l}- \\
-\end{array}$ & + \\
\hline $\begin{array}{l}\text { T17 } \\
\text { T18 }\end{array}$ & $\begin{array}{l}\text { EC } 1889 \mathrm{~S} \\
\text { EC } 1889 \mathrm{M}\end{array}$ & tsh e cvi/cva & $60,8 \%$ & $\begin{array}{c}\text { Intermediária } \\
\text { Alta }\end{array}$ & $\begin{array}{l}- \\
-\end{array}$ & - \\
\hline
\end{tabular}


DISCUSSÃO 


\section{DISCUSSÃO}

A colibacilose aviária é a principal doença secundária em aves e pode se manifestar nas condições modernas de criação, com alta densidade e níveis de estresse, tornando-se uma das maiores causas de mortalidade e prejuízos na avicultura, no mundo (GIMENO, 2009; ANDREATTI FILHO, 2007).

A correção do manejo e a inserção de medidas de biosseguridade efetivas devem ser prioritárias para o sucesso desta criação animal, uma vez que a restrição ao uso de agentes antimicrobianos como promotores de crescimento é cada vez maior. Neste contexto, a vacinação e decorrente proteção contra a doença surgem como uma alternativa para diminuir os prejuízos que podem ser gerados (FERREIRA; KNÖBL, 2009).

O desenvolvimento de vacinas vivas que protejam os animais sem ocasionar reações adversas é considerada a melhor alternativa para o êxito na criação de aves. O presente estudo selecionou cepas de E. coli aviária para a atenuação de sua patogenicidade por mutação induzida por substância química.

E. coli é uma espécie bacteriana bastante versátil, com alto grau de plasticidade genômica, através da perda ou ganho de genes, induzindo a aquisição de resistência a inúmeros antimicrobianos (RASKO et al., 2008). A capacidade de bactérias adquirirem e transferirem genes de resistência a outras bactérias é extremamente grande (CYRIL, 2006).

Bactérias com mutações podem ser candidatas a vacinas vivas para serem usadas na avicultura industrial, principalmente, em frangos de corte, pois pode ocorrer diminuição de sua virulência e preservação de sua imunogenicidade (LYNNE et al., 2012; NAGANO; KITAHARA; NAGAI, 2012)

A caracterização das cepas selecionadas neste estudo em relação a antimicrobianos encontrou resistência a vários destes medicamentos. Os resultados obtidos de resistência a lincomicina e penicilina e a suscetibilidade a enrofloxacina e ciprofloxacina foram semelhantes aos encontrados por Gomis et al. (2001), em E. coli isoladas de frangos de corte, no Canadá, que encontraram 100\% de resistência a lincomicina e penicilina, e $31,2 \%$ a neomicina e nenhuma resistência para a enrofloxacina e ciprofloxacina. 
Estudo realizado no Brasil, por Zanata et al. (2004), classificou 93\% das amostras de E. coli isoladas de aves, no Laboratório de Descalvado-SP, como multirresistentes. Estes verificaram que a tetraciclina foi a droga com maior resistência (76\%) e as de maior eficiência: o cloranfenicol, a ciprofloxacina, a enrofloxacina, o florfenicol e a gentamicina. Estes resultados não estão de acordo com os resultados deste estudo, que encontrou $22,22 \%$ de resistência a tetraciclina e a fosfomicina como o medicamento de maior eficiência.

Os resultados encontrados na literatura com respeito à suscetibilidade a antibióticos em bactérias isoladas de aves de produção são bastante divergentes, e isto se relaciona com a liberação de uso dos mesmos nos diversos países, e a consequente utilização desses em granjas como tratamento e principalmente como promotores de crescimento (BUTAYE; DEVRIESE; HAESEBROUK, 2003, TURNIDGE, 2004).

A opção por indução de resistência a rifampicina como marcador ocorreu em função desta não ser utilizada em aves comerciais e a possibilidade de rapidez neste processo, já demonstrado desde 1946 com o uso deste antibiótico para o tratamento de Mycobacterium tuberculosis e a aquisição rápida de resistência (CROFTON; MITCHISON, 1948). A rifampicina liga-se à subunidade $\beta$ da RNA polimerase, codificada pelo gene $r p o B$, inibindo a etapa de transcrição. A elevada resistência a este fármaco é com frequência devido a mutações pontuais no gene rpsl, com as mutações mais comuns no codon K43 e K88 (SREEVATSAN et al., 1996).

Outro antibiótico selecionado para a indução de resistência foi a estreptomicina que inibe a tradução do RNA mensageiro (mRNA), afetando a eficiência desta tradução (GARVIN; BISWAS; GORINI, 1974). A resistência ocorre por mutações no alvo do fármaco, mais especificamente nos ribossomos, sendo o principal sítio de mutação o gene rpsL, que codifica uma proteína ribossomal onde ocorrem mutações resultando na substituição de um único aminoácido. Um segundo mecanismo da resistência ocorre por alterações no gene que codifica o RNA 16S (rrs) em duas regiões diferentes e um terceiro mecanismo de resistênciat pode estar relacionado a trocas na entrada do fármaco para o interior da célula bacteriana (COOKSEY et al., 1996).

$\mathrm{Na}$ impossibilidade de indução de resistência aos dois antibióticos citados acima se optou pela indução de resistência com o ácido nalidíxico na cepa EC 1669 S. Únicas mutações pontuais em regiões do DNA determinantes de resistência a 
quinolonas, nas subunidades do gene gyrA, no códon 83 e 87 foram atribuídas aos altos níveis de resistências a este antibiótico (HOPKINS; ARNOLD; THREFALL, 2007).

As cepas selecionadas neste estudo eram na sua maioria dos sorogrupos $\mathrm{O} 2$, O78 e O119, pois foram isolados de surtos de colibacilose, nas granjas e incubatórios e são associadas a vários fatores de virulência (VIDOTTO et al., 1990; DHO-MOULIN; FAIRBROTHER, 1999; MENÃO et al., 2002).

Apesar de existirem estudos, os mecanismos exatos de virulência utilizados por este micro-organismo, nas aves, ainda não foram totalmente elucidados. Embora a expressão de diversos fatores de virulência por E. coli possam afetar os processos celulares e resultar em diferentes manifestações clínicas nas aves (EWERS et al., 2004; DZIVA; STEVENS, 2008; TUNTUFYE et al., 2012), ainda não foram associados fatores de virulência que possam ser fundamentais para a virulência de cepas de APEC (DHO-MOULI; FAIRBROTHER, 1999, HORNE et al., 2000; JANBEN et al., 2001).

Todas as cepas selvagens testadas foram positivas para o gene iuc e irp2, cinco delas para os genes iss, seis para tsh e três para cvi/cva, sendo estes normalmente associados a APEC (DZIVA; STEVENS, 2008; DELICATO et al., 2002).

A resistência ao sistema complemento pode ter um papel importante na virulência de APEC, pois o gene iss foi associado com a resistência ao sistema complemento por amostras de E. coli, o qual foi detectado significantemente de APEC do que de E. coli isolada de aves saudáveis (IKE et al., 1992, NOLAN; WOOLEY; COOPER, 2002, NOLAN et al., 2003, RODRIGUEZ-SIEK et al., 2005).

PFAFF-McDONOUGH et al. (2000) encontraram o gene iss em 78,7\% de em cepas de aves com colibacilose, enquanto este gene foi detectado em $16 \%$ de cepas isoladas de aves saudáveis e Delicato et al. (2002) encontraram $27,5 \%$ em aves com colibacilose.

Os resultados encontrados neste estudo coincidem com aqueles de Yaguchi et al. (2007) que pesquisaram os fatores de virulência em cepas de $E$. coli aviária isoladas no Japão. Os sorogrupos O1, O2, e 078 foram detectados em 56 de 125 cepas (44,8\%) isoladas de frangos doentes contra 13 em 100 (13\%) cepas isoladas de aves sadias e identificaram que os genes iss, iutA e tsh estavam amplamente distribuídos nas amostras patogênicas. 
O gene tsh foi detectado em cepas de E. coli isoladas de aves com colibacilose, sendo que Delicato et al. (2002) encontraram este gene em 39,5\% das amostras isoladas no Brasil. Johnson et al. (2008) analisaram 994 amostras de E. coli isoladas de aves com relação aos fatores de virulência e identificaram os genes iutA, hlyF, iss, iroN e ompT como os mais associados com APEC altamente patogênica.

Circella et al. (2012) isolaram E. coli de lesões de aves com colibacilose e de conteúdo fecal de aves sadias. A presença de genes de virulência, com exceção de astA foi associada mais frequentemente com cepas de APEC. Os genes cva/cvi, tsh, irp2, e iucD foram mais relatados em isolados de colibacilose.

Neste estudo, ocorreram alterações na detecção de fragmentos gênicos analisados, uma vez que apresentaram reações negativas para alguns genes após a exposição à substância mutagênica, sugerindo que possa ter ocorrido perda de sequência de nucleotídeos, troca ou inserção destes.

Três das cepas estudadas apresentaram modificações em genes de virulência. A cepa EC 269 após a exposição à substância mutagênica não apresentou os genes cvi/cva e sfal e ausência de bandas no teste de AFLP, existindo $76,9 \%$ de similaridade à cepa selvagem. Os resultados encontrados no teste de patogenicidade em pintinhos de um dia, apontou mudança em sua patogenicidade, ou seja, de intermediária para baixa patogenicidade, entretanto não houve diferença significativa no escore de lesões.

A cepa EC 1869 não apresentou os genes tsh, sfal e astA após a exposição à substância mutagênica. Houve uma grande modificação na detecção de bandas no teste de AFLP, ocorrendo apenas $40 \%$ de similaridade com a cepa selvagem. Também ocorreu mudança de patogenicidade, uma vez que esta cepa se apresentou não patogênica e apresentou diferenças significativas no escore de lesões.

A cepa EC 1889 não apresentou os genes tsh e cvi/cva após a exposição à substância mutagênica. A similaridade entre as cepas antes e após a exposição à substância mutagênica foi de 60,8\%, entretanto, não houve diferença em patogenicidade, sendo ambas classificadas como não patogênicas e sem diferença significativa no escore de lesões. Estes resultados sugerem que as modificações genéticas sofridas por esta cepa possam ter ocorrido em segmentos gênicos que não estão envolvidos na patogenicidade. 
Considerando a ausência de genes de virulência e o escore de lesão encontrado nas cepas estudadas é possível sugerir que o gene astA tenha importância na atenuação da patogenicidade de $E$. coli aviária, uma vez que ocorreu uma diminuição de patogenicidade com as amostras EC 269 M e EC 1869 M e escore de lesão menor com as amostras EC 713 M e EC 1299 M que apresentam ausência deste gene.

A maioria dos estudos de fatores de virulência em APEC envolvem genes que codificam as adesinas, o sistema de aquisição de ferro, as hemolisinas e os fatores envolvendo a resistência ao soro (EDELMAN et al., 2003; KOSTAKIOTI; STATHOPOULOS, 2004). Entretanto, a interação entre uma bactéria e células eucarióticas depende também de outros fatores, como a presença de citocinas e de toxinas (ANTAO; WIELER, EWERS, 2003).

O sistema de secreção tipo VI também foi associado com a patogenicidade de APEC. Mutantes com genes deletados deste sistema demonstraram diminuição nos processos de adesão e invasão de células e virulência atenuada em experimentos in vivo (PACE et al., 2010).

No teste de AFLP utilizou-se somente uma enzima de restrição, o que possivelmente pode explicar a ausência de alterações de bandas na cepa EC 713, embora tenha ocorrido alteração na patogenicidade e escore de lesões. Nesta cepa pode ter ocorrido modificações genéticas que possibilitaram a atenuação de sua patogenicidade, apesar de não ter ocorrido alterações nos genes de virulência estudados.

Os pintinhos SPF utilizados no teste de patogenicidade são sensíveis a $E$. coli, entretanto algumas cepas selecionadas como patogênicas não foram assim classificadas. Isto pode ser atribuído à perda de plasmídeo no armazenamento destas cepas e consequente alteração do resultado de patogenicidade.

A atenuação induzida por mutação pode representar uma opção para o desenvolvimento dessas vacinas atenuadas. Peighmbari et al. (2002) testaram duas vacinas elaboradas com cepas de E. coli com mutações, dos sorogrupos 02 e O78, em frangos de corte e concluíram que as aves vacinadas com o sorogrupo 02 apresentaram diferença significativa na redução de lesões em sacos aéreos quando comparadas as aves do grupo controle. 
Kwaga et al. (1994) testaram uma cepa de E. coli do sorogrupo O2, com mutação no gene carAB, por via oral, em perus de quatro semanas de idade e concluíram que as aves foram completamente protegidas da infecção após o desafio com a cepa homóloga.

A grande maioria das vacinas contra a colibacilose aviária disponíveis no mercado são inativadas com adjuvante oleoso o que inviabiliza a sua utilização em frango de corte. Vacinas vivas com cepas atenuadas são consideradas alternativas atraentes para a vacinação de aves, pois o tratamento da colibacilose aviária passou a ser dificultado nos últimos anos devido à maioria das amostras de $E$. coli presentes no campo apresentarem resistência a inúmeros antibióticos, provocada pelo extensivo uso de agentes antimicrobianos como promotores de crescimento por via água de bebida ou ração e também utilizados como terapêutica (BYWALTER, 2005).

Outras vantagens para a utilização de vacinas vivas são o custo mais baixo, a possível utilização de vacinação por via aerossol ou água de bebida. Entretanto, o processo de atenuação destas cepas não é rápido e simples, por isso diferentes métodos foram utilizados como a indução de modificações genéticas e consequente atenuação da bactéria (PEIGHAMBARI et al., 2002; REVOLLEDO; FERREIRA, 2010; AMOAKO et al., 2004).

Lynne et al. (2006) desenvolveram uma vacina contra a colibacilose aviária com os sorotipos $\mathrm{O} 2$ e $\mathrm{O} 78$, com a proteína recombinante iss e encontraram que as aves desenvolveram títulos de anticorpos após a vacinação. As aves vacinadas tiveram lesões menores após o desafio com as cepas homólogas quando comparadas as aves não vacinadas.

Amoako et al. (2004) desenvolveram uma vacina viva atenuada de E. coli para administração por via oral ou aerossol. Esta possui cepas que apresentaram mutações espontâneas e dependentes de estreptomicina (str-dependentes), geradas a partir de cepas virulentas com mutação na região fur do cromossomo bacteriano. Após a vacinação das aves e desafio com as cepas homólogas a vacina só produziu proteção significativa quando foram administradas três doses, com um, 14 e 28 dias de idade.

O teste de patogenicidade realizado neste estudo mostrou que cinco cepas analisadas modificaram a patogenicidade após a exposição à substância mutagênica, ocorrendo redução na patogenicidade e indicando uma atenuação da virulência pela substância mutagênica utilizada. Ocorreu uma exceção, a cepa EC 
1889 foi classificada inicialmente como apresentando patogenicidade intermediária e após a exposição à substância química foi definida como de alta patogenicidade. Como esta classificação se baseia no número de pintinhos mortos, em dez dias de observação e a alteração de classificação foi devido à morte de apenas uma ave, a realização de outros experimentos, com este objetivo devem ser realizados para a comprovação deste resultado.

Em duas cepas analisadas ocorreu atenuação da patogenicidade a pintinhos e redução no escore de lesão após a exposição à substância mutagênica. Desta forma, estas apresentam um potencial para o desenvolvimento de vacinas para aves. 


\section{CONCLUSÕES}

- A substância mutagênica não alterou a suscetibilidade das nove cepas que apresentavam um perfil de multirresistência.

- Os antimicrobianos utilizados como marcadores genéticos foram eficientes na indução de resistência nas cepas de E. coli selecionadas.

- A substância mutagênica utilizada alterou o perfil de genes de virulência em três cepas de E. coli estudadas.

- O perfil de bandas no AFLP se modificou em oito cepas, após a exposição à substância mutagênica.

- A exposição à substância mutagênica foi eficiente na diminuição da patogenicidade a pintinhos em quatro cepas analisadas.

- Ocorreu atenuação na patogenicidade a pintinhos com as cepas EC $713 \mathrm{M} \mathrm{e}$ EC 1869 M, pela redução da patogenicidade e escore de lesões, e estas apresentam potencial de serem usadas na produção de vacinas. 


\section{REFERÊNCIAS}

ABDUL-AZIZ, T. A.; EL-SUKHON, S. N. Chickens hyperimmunized with Escherichia coli J5 strain are protected against experimental challenge with Escherichia coli $\mathrm{O78}$ serotype. Veterinary Research Communications, v. 22, 7-9, 1998.

AMOAKO, K. K.; PRYSLIAK, A. A.; POTTER, A. A.; COLLINSON, S. K.; KAY, W. W.; ALLAN, B. J. Attenuation of an avian pathogenic Escherichia coli strain due to mutation in the rpsL gene. Avian Diseases, v. 48, p. 19-25, 2004.

ANDREATTI FILHO, R. L. Saúde aviária e doenças. São Paulo: Roca, 2007. 314 p.

ANTÃO, E. M.; WIELER, I. H.; EWERS, C. Adhesive threads of extraintestinal pathogenic Escherichia coli. Gut Pathologens, v. 1, p.1-22, 2009.

APINCO. Associação dos produtores de pintos de corte. Disponível em: <www.facta.org.br $>$. Acesso em 12 de nov. de 2012.

ARAUJO, J. A.; SILVA, J. H. V.; AMÂNCIO, A. L. L.; LIMA, M. R.; LIMA, C. B. Uso de aditivos na alimentação de aves. Acta Veterinária Brasílica, v. 1, p. 69-77, 2007.

ARP, L. H.; JENSEN, A. E. Piliation, hemagglutination, motility and generation time of Escherichia coli that are virulent or avirulent of turkeys. Avian Diseases, v. 24, p. 153-161, 1980.

BARNES, H. J.; VAILLANCOURT, J. P.; GROSS, W. B. Colibacilosis. In: Saif, Y. M. Diseases of poultry. 11. ed. Ames, lowa State: University Press, 2003. p. 631-656.

BAUER, A. W, KIRBY, E. M. Antibiotic Susceptibility Testing by Standardized Single Disk Method. American Journal of Clinical Pathology, v. 45, p. 493-496, 1966.

BETTELHEIM, K. A. Biochemical characteristics of Escherichia coli. In: GYLES, C. L. (Ed.). Escherichia coli in domestic animals and humans. UK: Cab International, 1994. chap. 1, p. 3-30.

BHAKDI, S.; MACKMAN, N.; NICAUD, J. M.; HOLLAND, I. B. Escherichia coli hemolysin may damage target cell membranes by generating transmembrane pores. Infection and immunity, v.52, p.63-69, 1986.

BOOM, R.; SOL, C. J. A.; SALIMANS, M. M. M.; JANSEN, C. L.; WERTHEIN-VAN DILLEN, P. M. E.; VAN DER NOORDAA, J. Rapid and simple method for purification of nucleic acids. Journal of Clinical Microbiology, v.28, p.495-503, 1990.

BRASIL. Ministério da Agricultura e do Abastecimento. Disponível em http://www.agricultura.gov.br/animal/exportacao. Acesso em: 30 abr. 2012.

BRÉE, A.; DHO, M.; LAFONT, J. P. Comparative infectivity for axenic and specificpathogen-free chickens of $\mathrm{O} 2$ Escherichia coli strains with or without virulence factors. Avian Diseases, v. 33, p. 134-139, 1989. 
BUTAYE, P.; DEVRIESE, L. A.; HAESEBROUK, F. Antimicrobial growth promoters used in animal feed: effects of less well known antibiotics on gram-positive bactéria. Clinical Microbiology Reviews, v. 16, p. 175-188, 2003.

BYWALTER, R. J. Identification and surveillance of antimicrobial resistance dissemination in animal production. Poultry Science, v. 84, p. 644-648, 2005.

CAMPOS, T. A.; STEHLING, E. G.; FERREIRA, A.; CASTRO, A. F. P.; BROCCHI, A.; SILVEIRA, W. D. Adhesion properties fimbrial expression and PCR detection of adhesion-related genes of avian Escherichia coli strain. Veterinary Microbiology, v. 106, p. 275-285, 2005.

CIRCELLA, E.; PENNELLI, D.; TAGLIABUE, S.; CAMARDA, A. Virulence-associated genes in avian pathogenic Escherichia coli from laying hens in Apulia, Southern Italy. British Poultry Science, v. 53, p. 465-470, 2012.

COOKSEY, R. C.; MORLOCK, G.P.; MCQUEEN, A.; GLICKMAN, S. E.; CRAWFORD, J.T. Characterization of streptomicyn resistance mechanism among Mycobacterium tuberculosis isolates from New York City. Antimicrobial Agents and Chemotherapy, v. 40, p.1186-1188, 1996.

CLARKE, C. R. Anitmicrobial resistance. Veterinary Clinics Small Animal Practice, v. 36, p. 987-1001, 2006.

CROFTON, J.; MITCHISON, D. A. Streptomycin Resistance in Pulmonary Tuberculosis. Britishi Medical Journal, v. 11, p. 1009-1015, 1948.

CYRIL, R. C. Antmicrobial resistance. Veterinary Clinics Small Animal Practice, v. 36, p. 987-1001, 2006.

DELICATO, E. R.; BRITO, B. G.; KONOPATZKI, A. P.; GAZIRI, L. C.; VIDOTTO, M. C. Ocurrence of the temperature-sensitive hemagglutinin among avian Escherichia coli. Avian Diseases, v. 46, p. 713-716, 2002.

DHO-MOULIN, M.; FAIRBROTHER, J. M. Avian pathogenic Escherichia coli (APEC). Veterinary Research, v. 30, p. 299-316, 1999.

DOZOIS, M. C.; CLÉMENT, S.; DESAULTELS, C.; OSWALD, E.; FAIRBROTHER, J. $M$. Expression of $P, S$ and $F 1 C$ adhesins by cytotoxic necrotizing factor 1-producing Escherichia coli from septicemic and diarrheic pigs. FEMS Microbiology Letters, v. 152, p. 307-312, 1997.

DZIVA, F.; STEVENS, M. P. Colibacilosis in poultry: unravelling the molecular basis of virulence of avian pathogenic Eschercihia coli in their natural hosts. Avian Pathology, v. 37, p. 355-366, 2008.

EDELMAN, S.; LESKELA, S.; RON, E.; APAJALAHTI, J.; KORHOMEN, K. In vitro adhesion of na avian pathogenic Escherichia coli 078 strain to surfaces of the chicken intestinal tract and to ilcal mucus. Veterinary Microbiology, v. 91, p. 41-56, 2003. 
EWERS, C.; JANSSEN, T.; KIESSLING, S.; PHILIPP, H. C.; WIELER, L. H. Molecular epidemiology of avian pathogenic Escherichia coli (APEC) isolated from colisepticemia in poultry. Veterinary Microbiology, v. 104, p. 91-101. 2004.

EWERS, C., LI; G., WILKING, H.; KIESSLING, S.; ALT, K.; ANTÃO, E. M., LATURNUS, C.; DIEHL, I.; GLODDE, S.; HOMEIER, T.; BÖHNKE, U.; STEINRÜCK, H.; PHILIPP, H. C.; WIELER, L. H. Avian pathogenic, uropathogenic, and newborn meningitis-causing Escherichia coli: how closely related are they? International Journal of Medical Microbiology, v. 297, p. 163-176, 2007.

FANTINATTI, F.; SILVEIRA, W. D.; CASTRO, A. F. P. Characteristics associated with pathogenicity of avian septicaemic Escherichia coli strains. Veterinary Microbiology, v. 41, p. 75-86, 1994.

FERREIRA, A. J. P.; KNÖBL, T. Colibacilose Aviária. In: BERCHIERI JR., A.; SILVA, E. N.; DI FABIO, J.; SEST, L.; ZUANAZE, M. A. Doenças das Aves, $2^{a}$ Ed. Campinas: Ed. Facta, 2009. 1102 p.

FERREIRA, A. J. P.; REVOLLEDO, L.; FERREIRA, C. S. A. Colibacilose. In: REVOLLEDO, L.; FERREIRA, A. J. P. Patologia aviária. Barueri: Manole, p. 67-74, 2009.

FLEMMING, J. S. Utilização de leveduras, probóticos e mananoligossacarídeos (MOS) na alimentação de frangos de corte. 2005. 109 f. Tese (Doutorado em Tecnologia de Alimentos) - Universidade Federal do Paraná, Paraná, 2005.

FRANCO, B. D. G. M.; LANFGRAF, M. Microbiologia dos alimentos. São Paulo: Editora Atheneu, 2006. 182 p.

FROMER, A., FREIDLIN, P. J.; BOCK, R. R., LEITNER, G.; CHAFFER, M.; HELLER, E. D. Experimental vaccination of young chickens with a live, non-pathogenic strain of Escherichia coli. Avian Pathology, v. 23, p.425-433, 1994.

GARVIN, R.T., BISWAS, D.W., GORINI, L. The effects of streptomycin or dihydrostreptomicin binding to $16 \mathrm{~S}$ rRNA or to $30 \mathrm{~S}$ ribossomal subunits.

Proceedings of the National Academy Sciences of the United States of America, v. 71, p. 3814-3818,1974.

GIMENO, E. Doenças aviárias na América Latina. In: REVOLLEDO, L.; FERREIRA, A. J. P. Patologia Aviária. Baueri: Manole, 2009, p. 2-5.

GOMIS, S. M.; RIDDELL, C.; POTTER, A. A.; ALLAN, B. J. Phenotypic and genotypic characterization of virulence factors of Escherichia coli isolated from broiler chickens with simultaneous occurence of cellulitis and other colibacilosis lesions. The Canadian Journal of Veterinary Research, v. 65, p. 1-6, 2001.

GOMIS, S.; BABIUK, L.; ALLAN, B.; WILSON, P.; WATERS, E. HECKER, R.; POTTER, A. Protection of chickens against a lethal challenge of Escherichia coli by vaccine containing $\mathrm{CpG}$ oligodeoxynucleotides as an adjuvant. Avian Diseases, v. 51 , p. 78-83, 2007. 
GOREN, E. Observations on experimental infection of chicken with Escherichia coli. Avian Pathology, v. 7, p.213-224, 1978.

GREGERSEN, R. H.; CHRISTENSEN, H.; EWERS, C.; BISGAARD, M. Impact of Escherichia coli vaccine in parent stock mortality, first week mortality of broilers and population diversity of E. coli vaccinated flocks. Avian Pathology, v. 39, p. 287-295, 2010.

HELLER, E. D.; LEITNER, G.; DRABKIN, N.; MELAMED, D. Passive immunisation of chicks against Escherichia coli. Avian Pathology, v. 19, p. 345-354, 1990.

HIRSH, D. C.; ZEE, Y. C. Microbiologia veterinária. Rio de Janeiro: Guanabara Koogan, 2003, 446p.

HOEPELMAN, A. I. M.; TUOMANEM. E. I. Consequences of microbial attachment: directing host cell functions with adhesins. Infection and Immunity, v. 60, p.17291733, 1992.

HOLLAND, B. I.; BLIGHT, M. A.; KENNY, B. The mechanism of secretion of hemolysin and other polipeptides from Gram-negative bacteria. Journal of Bioenergetics and Biomembranes, v. 22, p. 473-491, 1990.

HOPKINS, K. L.; ARNOLD, C.; THRELFALL, E. J. Rapid detection of gyrA and parC mutations in the quinolone-resistant Salmonella enterica using Pyrosequencing technology technology. Journal of Microbiological Methods, v. 68, p. 163-171, 2007.

HORNE, S. M.; PFAFF-MCDONOUGH, S. J.; GIDDINGS, C. W,; NOLAN, L. K. Cloning and sequencing of the iss gene from a virulent avian Escherichia coli. Avian Diseases, v.44, p.179-184, 2000.

IKE , K.; KAWAHARA, H.; DANBARA, H.; KUME, K. Serum resistance and aerobactin iron uptake in avian Escherichia coli mediated by conjugative 100megadalton plasmid. The Journal of Veterinary Medical Science, v. 54, p. 1091 1098, 1992.

JANBEN, T.; SCHWARZ, C.; PREIKSCHAT, P.; VOSS, M.; PHILIPP, H. C.; WIELER, L.H. Virulence-associated genes in avian pathogenic Escherichia coli (APEC) isolated from internal organs of poultry having died from colibacilosis. International Journal Medical Microbiology, v. 291, p. 371-378, 2001.

JOHNSON, T.; WANNEMUEHLER, Y.; DOETKOTT, C.; JOHNSON, S. J.; ROSENBERGER, S.; NOLAN, L. Identification of minimal predictors of avian pathogenic Escherichia coli virulence for use as rapid diagnostic tool. Journal of Clinical Microbiology, v. 46, p. 3987-3996, 2008.

JOUINI, A.; BEN SLAMA, K.; SÁENZ, Y.; KLIBI, N.; COSTA, D.; VINUÉ, L.; ZARAZAGA, M. BOUDABOUS, A.; TORRES, C. Detection of multiple-antimicrobial resistance and characterization of the implicated genes in Escherichia coli isolates 
from foods of animal origin in Tunis. Journal of Food Protection, v. 72, p. 10821089, 2009.

KALLENIUS, G.; MOLBY, R.; SVENSON, S. B.; WINBERG, J.; HULTBERG, H. Identification of a carbohydrate receptor recognized by uropathogenic Escherichia coli. Infection, v.8, p. 288-293, 1980.

KHARDORI, N. Antibiotics - Past, present, and future. The Medical Clinics of North America, v. 90, p. 1049-1076, 2006.

KONEMAN, E. W.; ALLEN, S. D.; JANDA, W. M.; SCRECKENBERGER, W. C. Diagnóstico microbiológico. 5 ed. Rio de Janeiro: Ed. Guanabara Koogan, 2001. $1465 \mathrm{p}$.

KOO, H. J.; WOO, G. J. Distribuition and transferability of tetracycline resistance determinants in Escherichia coli isolated from meat and meat products. International Journal of Food Microbiology, v. 145, p. 407-413, 2011.

KOSKATAKIOTI, M.; STATHOPOULOS, C. Functional analysis of the Tsh autotransporter from avian pathogenic Escherichia coli strain. Infection and Immunity, v. 72, p. 5548-5554, 2004.

KWAGA, J. K.; ALLAN, B. J.; VAN DER HURK, J. V.; SEIDA, H., POTTER, A. A. A carAB mutant of avian pathogenic Escherichia coli serogroup $\mathrm{O} 2$ is attenuated and effective as a live oral vaccine against colibacillosis in turkeys. Infection and Immunity, v. 62, p. 3766-3772, 1994.

LAFONT , J. P.; DHO, M. D.; D'HAUTEVILLE, H. M.; BREE, A.; SANSONETTI, P. J. Presence and expression of aerobactin genes in virulent strains of Escherichia coli. Infection and Immunity, v. 55, p. 193-197, 1987.

LATHAM, R. H.; STAMM, W. E. Role of fimbriated Escherichia coli in urinary tract infections in adult women: Correlation with localization studies. Journal of Infectious Diseases, v. 149, p. 835-840, 1994.

LEBEK, G.; GRUENIG, H. M. Relation between the hemolytic property and iron metabolism in Escherichia coli. Infection and Immunity, v.50, p.682-686, 1985.

LI, G.; LATURNUS, C.; EWERS, C.; WIELER, L. H. Identification of genes required for avian Escherichia coli septicemia by signature tagged mutagenesis. Infection and Immunity, v. 73, p. 2818-2827, 2005.

LODDI, M. M. Probiótico, prebiótico e acidificantes orgânicos em dietas para frangos de corte. 2003. 52 f. Tese (Doutorado em Zootecnia) - Faculdade de Ciencias Agrárias e Veterinárias, Universidade Estadual Paulista "Júlio de Mesquita Filho", Jaboticabal, 2003.

LYNNE, A. M.; SKYBERG, J. A.; LOGUE, C. M.; DOETKOTT, C.; FOLEY, S. L.; NOLAN, L. K. Characterization of a series of transconjugant mutants of an avian 
pathogenic Escherichia coli isolate for resistance to serum complement. Avian Diseases, v. 51, p. 771-776, 2007.

LYNNE, A. M.; KARIYAWASSAM, S.; WANNEMUEHLER, Y.; JOHNSON, S. J.; SINHA, A. S.; LYNNE, D. K.; MOON, H. W.; JORDAN, D. M.; LOGUE, C. M.; FOLEY, S. L.; NOLAN, L. K. Recombinant Iss as a potencial vaccine for avian colibacilosis. Avian Diseases, v. 56, p. 192-199, 2012.

MACKMAN, N.; NICAUD, J. M.; GRAY, L.; HOLLAND, I. B. Secretion of haemolysin by Escherichia coli. Current Topics in Microbiology and Immunology, v.125, p.159-181, 1986.

MCLAUCHLIN, J.; RIPABELLI, G.; BRETT, M. M.; THREFALL, E. J. Amplified fragment length polymorphism (AFLP) analysis of Clostridium perfringens for epidemiological typing. International Journal of Food Microbiology, v. 56, p. 2128, 2000.

MC PEAKE, S. J.; SMYTH, J. A; BALL, H. J. Characterization of avian Escherichia coli (APEC) associated with colisepticemic compared to faecal isolates from healthy birds. Veterinary Microbiology, v. 110, p. 245-253, 2005.

MARC, D.; DHO-MOULIN, M. Analysis of the cluster of na avian O2 strain of Escherichia coli: serogroup-specific sites within fimA and nucleotide sequence of fiml. Journal of Medical Microbiology, v. 44, p. 444-452, 1996.

MAURER, J. J.; BROWN, T. P.; STEFFENS, W. L.; THAYER, S. G. The occurrence of ambient temperature regulated adhesins, curli and the temperature sensitive hemagglutinin Tsh among avian Escherichia coli. Avian Diseases, v. 42, p.106-118, 1998.

MELAMED, D.; LEITNER, G.; HELLER, E. D. A vaccine against avian colibacillosis based on ultrasonic inactivation of Escherichia coli. Avian Diseases, v. 35, p. 17-22. 1991.

MELLATA, M.; DHO-MOULIN, M.; DOZOIS, C. M.; CURTISS III, R.; LEHOUX, B.; FAIRBROTHER, J. M.; Role of Avian Pathogenic Escherichia coli Virulence Factors in Bacterial Interaction with Chicken Heterophils and Macrophages. Infection and Immunity, v. 71, p. 494-503, 2003.

MENÃO, M. C.; FERREIRA, C. S. A.; CASTRO, A. G. M.; KNÖBL, T.; FERREIRA, A. J.P. Sorogrupos de Escherichia coli isolados de frangos com doença respiratória crônica. Arquivos do Instituto Biológico, v. 69, n. 4, p.15-17, 2002.

MENÃO, M. C. Biologia da vacinação. In: REVOLLEDO, L.; FERREIRA, A. J. P. Patologia Aviária. Barueri: Editora Manole Ltda, 2008, p. 386-393.

MILES, T.D.; McLAUGHLIN, W.; BROWN, P.D. Antimicrobial resistence of Escherichia coli isolates from broiler chickens and humans. Veterinary Research, v. 2, n. 7, 2006. 
MINISHEW, W. H.; JORGENSEN, J.; COUNTS, G. W.; FALKOW, S. Association of hemolysin prodution, hemagglutination of human erytrocytes, and virulence for chicken embryos of extra intestinal Escherichia coli isolates. Infection and Immunity, v. 20, p. 50-54, 1978.

MOL, O.; OUDEGA, B. Molecular and strutural aspects of fimbriae biosinthesis and assemply in Escherichia coli. FEMS Microbiology Letters, v. 19, p. 25-52, 1996.

MOON, H. W. Colonization factor antigens of Enterotoxigenic Escherichia coli in animals. Current Topics in Microbiology and Immunology, v. 151, p. 148-165, 1990.

NAGANO, T; KITAHARA, R.; NAGAI, S. An attenuated mutante of avian pathogenic Escherichia coli serovar O78: a possible live vaccine strain for prevention of avian colibacilosis. Microbiology and Immunology, v. 56, p. 605-612, 2012.

NAGARAJA, K. V. Patogenicidad de la Escherichia coli y los factores de stress en los pollos de engorde. Avicultura Profesional, v.10, p. 176-180, 1993.

NAKAZATO, G.; CAMPOS, T. A.; ATEHLING, E. G.; BROCCHI, M.; SILVEIRA, W. $O$. Virulence factors of avian pathogenic Escherichia coli. Pesquisa Veterinária Brasileira, v. 29, p. 479-486, 2009.

NATARO, J. P.; KAPER, J. B. Diarrheagenic Escherichia coli. Clinical Microbiology Reviews, v. 11, p. 142-201, 1998.

NAVEH, M. W.; ZUSMAN, T.; SKUTLSKY, E.; RON, E. Z. Adherence Pili in Avian Strains of Escherichia coli - Effect on Pathogenicity. Avian Diseases, v. 28, n. 3, p.651-661, 1984.

NEILANDS, J. B. Iron absortion and transport in microorganism. Annual Review of Nutrition, v. 1, p. 27-46, 1981.

NOLAN, L.K.; WOOLEY, R. E.; COOPER, R. K. Transposon mutagenesis used to study the role of complement resistance in the virulence of na avian Escherichia coli isolate. Avian Diseases, v. 36, p. 398-402. 2002.

NOLAN, L. K.; HORNE, S. M.; GIDDINGS, G. W.; FOLEY, S. L.; JOHNSON, T. J.; LYNNE, A. M.; SKYBERG, J. Resistance to serum complement iss, and virulence of avian Escherichia coli isolate. Veterinary Research Communications, v. 27, p. 101110, 2003.

OBENG, A. S.; RICKARD, H.; NDI, O.; SEXTON, M. Anitbiotic resistance, phylogenetic grouping and virulence potential of Escherichia coli isolated from faeces of intensively farmed and free range poultry. Veterinary Microbiology, v. 154, p. 305-314, 2012.

OFEY, I.; DOYLE, R. J. Regulation and expression of bacterial adhesins. In: OFEK, I.; DOYLE, R.J. (Ed.). Bacterial adhesion to cells and tissues. New York: Chapman \& Hall, 1993. p. 239-320. 
OLSEN, A.; JONSSON, A.; NORMARK, S. Fibronectin binding mediated by a novel class of surface organelles on Escherichia coli. Nature, v.338, p.652-5, 1989.

ORSKOV, I.; ORSKOV, F Serology of Escherichia coli Fimbriae. Progress in Allergy, v. 33, p.80-105, 1983.

PACE, F.; NAKAZATO, G.; PACHECO, A.; PAIVA, J. B.; SPERANDIO, V.; SILVEIRA, W. D. The Type VI System Plays a Role in Type 1 Fimbria Expression and Pathogenesis of an Avian Pathogenic Escherichia coli Strain. Infection and Immunity, v. 78, p. 4990-4998, 2010.

PEIGHAMBARI, S. M.; HUNTER, D. B.; SHEWEN, P. E.; GYLES, C. L. Safety, immunogenicity, and efficacy of two Escherichia coli cya crp mutants as vaccines for broilers. Avian Diseases, v. 46, p. 287-297, 2002.

PFAFF-McDONOUGH, S.J.; HOME, S.M.; GIDDINGS, C.W., EBERT, J. O.; DOETKOTT, C.; SMITH, M. H.; NOLAN, L. K. Complement resistance-related traits among Escherichia coli isolates from apparently health birds and birds with colibacillosis. Avian Diseases, v.44, p. 23-33, 2000.

POURBAKHSH, S. A.; DHO-MOULIN, M.; BREÉ, A.; DESAUTELS, C.; MARTINEAU-DOIZE B.; FAIRBROTHER, J. B. Localization of the in vivo expression of $P$ and $F 1$ fimbriae in chickens experimentally inoculated with patogenic Escherichia coli. Microbial Pathogenesis, v. 22, p. 231-341, 1997.

PROVENCE, D.L.; CURTISS, R. Role of $\mathrm{crl}$ in avian pathogenic Escherichia coli : a knockout mutation of $\mathrm{crl}$ does not affect hemagglutination activity, fibronectin binding, or curli production. Infection and Immunity, v.60, p.4460-7, 1992.

PROVENCE, D. L.; CURTISS III, R. Isolation and characterization of a gene involved in hemagglutination by avian pathogenic Escherichia coli strains. Infection and Immunity, v. 62, p. 1369-1380, 1994.

RASKO, D. A.; ROSOVITZ, M. J.; MYERS, G. S.; MONGODIN, E. F. FRICKE, W. F.; GAJER, P.; CRABTREE, J.; SEBAIHIA, M.; THOMSON, N. R.; CHAUDHURI, R.; HENDERSON, I. R.; SPERANDIO, V.; RAVEL, J. The pangenome structure of Escherichia coli: comparative genomic analysis of $E$. coli commensal and pathogenic isoaltes. Journal of Bacteriology, v. 190, p. 6881- 6893, 2008.

REVOLLEDO, L.; FERREIRA, A. J. Salmonella antibiotic-mutant strains reduce fecal shedding and organ invasion in broiler chicks. Poultry Science, v. 89, p. 2130-2140, 2010.

ROCHA, A. C. G. P.; ROCHA, S. L. S.; LIMA-ROSA, C. A. V.; SOUZA, G. F.; MORAES, L. S.; SALLE, F. O.; MORAES, L. B.; SALLE, C. T. P. Genes associated with pathogenicity of avian Escherichia coli (APEC) isolated from respiratory cases of poultry. Pesquisa Veterinária Brasileira, v. 28, p. 183-186, 2008.

ROE, M. T.; PILLAI, S. D. Monitoring and identifying antibiotic resistance mechanisms in bacteria. Poultry Science, v. 82, p. 622-626, 2003. 
RODRIGUEZ-SIEK, K. E.; GIDDINGS, C. W.; DOETKOTT, C.; JOHNSON, T. J.; NOLAN, L. K. Characterizing the APEC pathotype. Veterinary Research, v. 36, p. 241-256, 2005.

ROSSI, F.; ANDREAZZI, D. B. Resistência bacteriana: interpretando o antibiograma. São Paulo: Atheneu, 2005. 118 p.

SALLE, C. T. P.; MORAES, H. L. S. Prevenção de doenças/Manejo profilático/Monitoria. In: In: BERCHIERI JR., A.; SILVA, E. N.; DI FABIO, J.; SEST, L.; ZUANAZE, M. A. Doenças das Aves, 2ª Ed. Campinas: Ed. Facta, 2009. p. 1-17.

SCHOULER, C.; KOFFMANN, F.; AMORY, C.; LEROY-SÉTRIN, S.; MOULINSCHOULER, M. Genomic subtraction for the identification of putative new virulence factors of na avian pathogenic Escherichia coli strain of $\mathrm{O} 2$ serogroup. Microbiology, v. 150, p. 2973-2984, 2004.

SCHUBERT, S.; RAKIN, A.; KARCH, H.; CARNIEL, E.; HEESEMANN, J. Prevalence of the high pathogenicity island of Yersinia species among Escherichia coli strains that are pathogenic to humans. Infection Immunity, v. 66, p. 480-485,1998.

SILVA, E. N. Probiótico e prebiótico na alimentação de aves. In: CONFERÊNCIA APINCO DE CIÊNCIA E TECNOLOGIA AVÍCOLAS, 2000, Campinas, São Paulo. Anais... Campinas: FACTA, 2000, v. 2, p. 241-251.

SILVEIRA, W. D., FANTINATTI, F.; CASTRO, A. P. Transposon mutagenesis and membrane protein studies in avian colisepticaemic Escherichia coli strain. Brazilian Journal of Genetics, v. 17, p. 9-14, 1994.

SINGER, R. S.; HOFACRE, C. L. Potential impacts of antibiotic use in poultry production. Avian Diseases, v. 50, 161-172, 2006.

STATHOPOULOS, C.; PROVENCE, D. L.; CURTISS III, R. Characterization of the avian Escherichia coli hemagglutinin Tsh, a member the immunoglobulin A proteasetype family of autotransporter. Infection and Immunity, v. 67, p. 772-781, 1999.

STREVATSAN, S.; PAN, X.; STOCKBAUER, K. E.; WILLIAMS, D. L.; KREISWIRTH, B. N.; MUSSER, J. M. Characterization of rpsL and rrs mutations in streptomycinresistant Mycobacterium tuberculosis isolates from diverse geographic localities. Antimicrobial Agents Chemotherapy, v. 40, p. 1024-1026, 1996.

SUNDE, M.; NORSTRÖM, M. The prevalence of associations between and conjugal transfer of antibiotic resistance genes in Escherichia coli isolated from Norwegian meat and meat products. The Journal of Antimicrobial Chemotherapy, v. 58, p. 741-747, 2006.

SUSSMAN, M. Escherichia coli and human disease. In: SUSSMAN, M.

Escherichia coli Mechanisms of virulence. Cambridge: University Press, 1997. 
TENOVER, F. C. Mechanisms of antimicrobial resistance in bacteria. The American Journal of Medicine, v. 119, p. S3-S10, 2006.

THANASSI, D. G.; SAULINO, E. T.; HULTGREN, S. J. The chaperone/usher pathway: a major terminal branch of the general secretory pathway. Current Opinion in Microbiology, v. 1, p. 223-231, 1998.

TORTORA, G. J.; FUNKE, B. R.; CASE, C. L. Microbiologia. 8 ed. Porto Alegre: Artmed 2005. 920 p.

TRABULSI, L. R.; ALTERTHUM, F. Microbiologia. 4. São Paulo: Atheneu, 2005, $718 \mathrm{p.}$

TSUKAMOTO, T. PCR Method for Detection of K1 Antigen and Serotypes of Escherichia coli Isolated from Extraintestinal Infection. Kansenshogaku Zasshi, v. 71, n. 2, p. 125-129, 1997.

TUNTUFYE, H. N.; LEBEER, S.; GWAKISA, P. S.; GODDEERIS, B.M. Identification of avian pathogenic Escherichia coligenes that are induced in vivo during infection in chickens. Applied and Enviromental Microbiology, v. 78, p. 3343-3351, 2012.

TURNIDGE, J. Antibiotic use in animals - prejudiccs, perceptions and realitics. The Journal of Antimicrobial Chemotherapy, v. 53, p. 26-27, 2004.

VIDOTTO, M. C., MÜlleR, E. E., De FREITAS, J. C., AlFIERI, A. A.; GUIMARÃES, I. G.; SANTOS, D. S. Virulence factors of avian Escherichia coli. Avian Diseases, v.34, p.531-538, 1990.

WAKSMAN, G.; HULTGREN, S. J. Structural biology of the chaperone-usher pathway of pilus biogenesis. Nature Reviews Microbiology, v. 7, p. 765-774, 2009.

WEGENER, H. C.; AARESTRUP, P.; GERNER-SMIDT, P.; BAGER, F. Transfer of antibiotic resistant bacteria from animals to man. Acta Veterinaria Scandinavica, v. 92, p. 51-57, 1999.

WOOLEY , R. E.; GIBBS, P. S.; BROWN, T. P.; GLISSON, J. R.; STEFFENS W. L.; MAURER, J. J. Colonization of the chicken trachea by avirulent avian Escherichia coli transformed with plasmid pHK 11. Avian Diseases, v. 42, p. 194-198, 1998.

YAGUCHI, K.; OGITANI, T.; OSAWA, R.; KAWANO, M.; KOKUMAI, N.; KANESHIGE, T.; NORO, T.; MASUBUCHI, K.; SHIMIZU, Y. Virulence factors of avian pathogenic Escherichia coli strains isolated from chickens with colisepticemia in Japan. Avian Diseases, v. 51, p. 656-662, 2007.

YAGUCHI, K.; OHGITANI, T.; NORO, T.; SHIMIZU, Y. Vaccination of chicken with liposomal inactivated avian pathogenic Escherichia coli (APEC) vaccine by egg dropp or coarse spray administration. Avian Diseases, v. 53, p. 245-249, 2009. 
YAMAMOTO, S.; TERAI, A.; YURI, K.; KURAZONO, H.; TAKEDA, Y.; YOSHIDA, O. Detection of urovirulence factors in Escherichia coli by multiplex polymerase chain reaction. FEMS Immunology and Medical Microbiology, v. 12, p. 85-90, 1995.

YAMAMOTO, S.; ECHEVERRIA, P. Detection of the enteroaggregative Escherichia coli heat-stable enterotoxin 1 gene sequences in enterotoxigenic $E$. coli strains pathogenic for humans. Infection and Immunity, v. 64, p. 1441-1445, 1996.

YANG, H.; CHEN, S.; WHITE, D. G.; ZHAO, S.; MCDERMOTT, P.; WALKER, R.; MENG, J. Characterization of multiple-antimicrobial-resistant Escherichia coli isolates from diseased chickens and swine in China. Journal of Clinical Microbiology, v. 42, p.3483-3489, 2004.

YUNIS, R.; BEM-DAVID, A. HELLER, E. D.; CAHANER, A. Immunocompetence and viability under commercial conditions of broiler groups differing in growth rate and in antibody response toEscherichia coil vaccine. Poultry Science, v. 79, p. 810-816, 2000.

ZANATTA, G. F.; KANASHIRO, A. M. I.; CASTRO, A. L. S. P.; TESSARI, E. N. C.; PULICI, S. C. P. Suscetibilidade de amostras de Escherichia coli de origem aviária a antimicrobianos. Arquivos do Instituto Biológico, v. 71, p. 283-286, 2004. 